ELIANA PAULA PEREIRA

RELEVÂNCIA DO EIXO IMUNE-PINEAL NA RESPOSTA DE DEFESA PULMONAR DE RATOS EXPOSTOS À POLUIÇÃO ATMOSFÉRICA

Tese apresentada ao Programa de PósGraduação em Farmacologia do Instituto de Ciências Biomédicas da Universidade de São Paulo para a obtenção do Título de Doutor em Ciências. 
ELIANA PAULA PEREIRA

\section{RELEVÂNCIA DO EIXO IMUNE-PINEAL NA RESPOSTA DE DEFESA PULMONAR DE RATOS EXPOSTOS À POLUIÇÃO ATMOSFÉRICA}

Tese apresentada ao Programa de PósGraduação em Farmacologia do Instituto de Ciências Biomédicas da Universidade de São Paulo para a obtenção do Título de Doutor em Ciências.

Área de concentração : Farmacologia

Orientador : $\operatorname{Prof}^{\mathrm{a}} \mathrm{Dr}^{\mathrm{a}}$ Regina Pekelmann Markus

Versão original 
DADOS DE CATALOGAÇÃO NA PUBLICAÇÃO (CIP)

Serviço de Biblioteca e Informação Biomédica do

Instituto de Ciências Biomédicas da Universidade de São Paulo

๑) reprodução total

\section{Pereira, Eliana Paula}

Relevância do eixo imune-pineal na reposta de defesa pulmonar de ratos expostos à poluição atmosférica / Eliana Paula Pereira. -- São Paulo, 2016

Orientador: Profa. Dra. Regina Pekelmann Markus.

Tese (Doutorado) - Universidade de São Paulo. Instituto de Ciências Biomédicas. Departamento de Farmacologia. Área de concentração: Farmacologia. Linha de pesquisa: Cronofarmacologia.

Versão do título para o inglês: Relevance of the immune-pineal axis in rat lung defense response to air pollution.

$\begin{array}{lll}\text { 1. Melatonina 2. Eixo imune-pineal } & \text { 3. Poluição atmosférica } 4 .\end{array}$

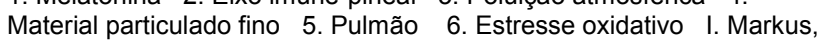
Profa. Dra. Regina Pekelmann II. Universidade de São Paulo. Instituto de Ciências Biomédicas. Programa de Pós-Graduação em Farmacologia III. Título. 
Candidato(a): $\quad$ Eliana Paula Pereira.

Título da Tese: $\quad$ Relevância do eixo imune-pineal na reposta de defesa pulmonar de ratos expostos à poluição atmosférica.

Orientador(a): $\quad$ Profa. Dra. Regina Pekelmann Markus.

A Comissão Julgadora dos trabalhos de Defesa da Tese de Doutorado, em sessão pública realizada a .l. considerou
( ) Aprovado(a)
( ) Reprovado(a)

\begin{tabular}{|c|c|}
\hline Examinador(a): & Assinatura: ........... \\
\hline & Nome: .................... \\
\hline & Instituição: ........ \\
\hline Examinador(a): & Assinatura: ......... \\
\hline & Nome: ...... \\
\hline & Instituição: ......... \\
\hline Examinador(a): & Assinatura: .......... \\
\hline & Nome: .............. \\
\hline & Instituição: ......... \\
\hline Examinador(a): & Assinatura: \\
\hline & Nome: ............. \\
\hline & Instituição: ..... \\
\hline Presidente: & Assinatura: . \\
\hline & Nome: ........................................... \\
\hline & 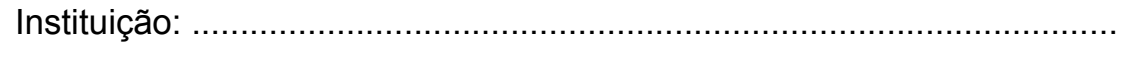 \\
\hline
\end{tabular}




\section{CerTIFICADO}

Certificamos que o protocolo registrado sob $n^{\circ} \mathbf{0 5 7}$ nas fls. $\mathbf{1 2 8}$ do livro 02 para uso de animais em experimentação, sob a responsabilidade do Prof(a) Dr(a)) Regina Pekelmann Markus, Coordenador (a) da Linha de pesquisa "O efeito da poluição atmosférica urbana de São Paulo sobre a produção de melatonina pela glândula pineal e na reatividade das células endoteliais de ratos" do qual participam o(s) Eliana Paula Pereira, está de acordo com os Princípios Éticos de Experimentação Animal adotado pela Sociedade Brasileira de Ciência de Animais de Laboratório (SBCAL) e foi aprovado pela COMISSÃO DE ÉTICA NO USO DE ANIMAIS (CEUA) em 08.05.2012, com validade de 4 anos.

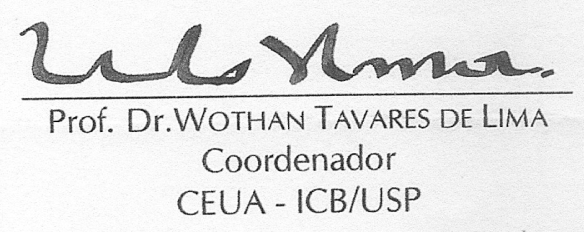

São Paulo, 09 de maio de 2012.

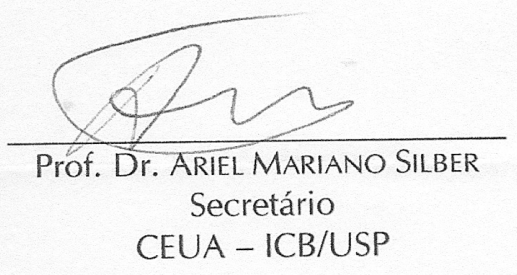


À minha família, ao amor mais profundo experimentado... 


\section{AGRADECIMENTOS}

\section{O meu muito obrigada ...}

À Regina, minha orientadora, "grande madre superiora ", obrigada pela oportunidade, pela paciência, pelos ensinamentos e principalmente pelo exemplo. Minha eterna gratidão e admiração por você !!!

À Ciência que nos instiga, que nos ensina a ser persistente, a ter humildade, a perseguir pistas e que nos presenteia e nos surpreende todos os dias.

Aos professores Zulma e Pedro pelos ensinamentos científicos e técnicos, pela amizade e boas risadas.

Ao Professor Saldiva, virtuoso, o guardião da qualidade atmosférica de São Paulo cuja inestimável colaboração rendeu e renderá trabalhos interessantíssimos.

Ao professor Marcílio e à Claudia que sem me conhecerem, sem qualquer indicação me concederam uma acolhida generosíssima cuja parceria me inseriu em um novo contexto da ciência.

À professora Lúcia que me apresentou ao mundo da sinalização redox.

À Claudinha, minha companheira de experimentos noturnos, fonte de inovação e inspiração. Quantas noites e madrugadas sem dormir e muitas histórias para contar !!!

Ao San, meu amigo, sempre disposto a me ajudar, a me ensinar, a discutir as mais malucas das idéias, de quem eu tenho o apoio integral e a quem eu sou muito grata e que muito admiro. Não sei o que seria de mim sem você nesta aventura científica !!!

À Marina pela gentileza, companheirismo e descobertas.

Ao Edu e a Erika pela orientação, disponibilidade e exemplos de pesquisadores.

Aos queridos amigos e companheiros do laboratório de Cronofarmacologia, Edu, Déboras, Vanderlei, Michelle, Letícia, Priscila, Aldeídea, Everton, Lívia, Camila, Marco, Leila, Gabrielas, Kely, Daiane, Luciana e Luís por fazerem do laboratório um ambiente saudável, de amizade e de muita colaboração.

À Mariana e ao Marco, amigos que ganhei nesta jornada "poluída", vocês foram extremamente prestativos e presentes, sem a preciosa ajuda de vocês este trabalho não poderia ter sido concluído.

Aos colegas e professores do Departamento de Fisiologia do Instituto de BiociênciasUSP.

Aos colegas e professores do Departamento de Farmacologia do Instituto de Ciências Biomédicas-USP. 
Aos funcionários, aos colegas Natália, Gabriel, Luciano, Karla, Adair e aos professores do Departamento de Patolologia da Faculdade de Medicina-USP, que sempre foram muito gentis.

Às queridas secretárias do departamento de Farmacologia, Monica, Camila, Miriam e Selma que nunca mediram esforços pra me ajudar.

Aos bibliotecários do ICB que sempre foram muito prestativos em todas as minhas dúvidas e solicitações. Um agradecimento especial à Tereza e à Renata cuja amabilidade e gentileza tornaram os prazos desta tese possíveis. Vocês não existem !!!!

Aos bioteristas, sem vocês nossos modelos nunca seriam viáveis.

Aos meus pais, Sueli e Almir in memorian, seres humanos incríveis, modelos de amor, fé e generosidade. Agradeço o apoio incondicional de vocês às minhas investidas desde a infância.

Às minhas queridas filhas, Helena e Isabella, amores da minha vida, que trazem tantas alegrias e que sempre me recebem com um sorriso no rosto o que me faz acreditar que o amanhã será melhor. Com quem aprendo todos os dias e que equivocamente, achamos que estamos ensinando. Obrigada por compreenderem a minha ausência e por torcerem por mim e pelos ratinhos !!!

Ao Rodrigo, meu marido, cúmplice de todas as horas, parceiro de uma vida com quem construí uma família maravilhosa. Com certeza você é um dos responsáveis por esta conquista.

Aos meus irmãos, Almir in memorian e Cássio in memorian, que sempre me mostraram com suas ações o significado da determinação, da disciplina, da persistência, da versatilidade e da amizade.

Aos meus sogros, Cacilda e Roberto, figuras iluminadas, com quem tenho o privilégio de conviver, por quem meu respeito, admiração e meu carinho são infinitos.

Aos meus cunhados, concunhados e sobrinhos que são um presente e um bônus que ganhei na minha relação com o Rodrigo.

À Astrid, minha querida amiga, a irmã que a vida me trouxe.

À Bibica, queridona, pelas longas conversas ou melhor, pela "terapia ".

Às Farmiguinhas pelo companheirismo e palavras encorajadoras.

À minha admirável afilhadinha, Maria Vitória, tão jovem e tão madura.

Àqueles que por ventura tenha me esquecido de nomear aqui devido à minha péssima memória que me deixa tantas vezes na mão !!!

Porfim, agradeço, ao fundamental e inestimável apoiofinanceiro da FAPESP , CNPq e CAPES. 
" O correr da vida embrulha tudo. A vida é assim: esquenta e esfria, aperta e daí afrouxa, sossega e depois desinquieta. O que ela quer da gente é coragem." 


\section{RESUMO}

PEREIRA, E. P. Relevância do eixo imune-pineal na resposta de defesa pulmonar de ratos expostos à poluição atmosférica. 2016. $117 \mathrm{f}$. Tese (Doutorado em Farmacologia) - Instituto de Ciências Biomédicas, Universidade de São Paulo, São Paulo, 2016.

Durante a montagem de uma resposta inflamatória há uma alternância transiente entre a produção central de melatonina, pela pineal, para a produção periférica, por células de defesa. Um mesmo estímulo reconhecido como um sinal de perigo desencadeia a supressão de melatonina noturna pela pineal e a indução da produção em células imunocompetentes. Essas evidências formam a base experimental que fundamentam a existência do eixo imune-pineal (Markus et al., 2007, 2013). Esta comunicação bidirecional e coordenada entre a pineal e as células imunocompetentes é importante para a montagem e finalização eficiente de uma resposta inflamatória. A poluição do ar é um importante fator de risco para as populações urbanas com efeitos deletérios sobre a saúde e aumento de morbidade e mortalidade. Neste estudo in vivo caracterizamos que a exposição aguda à poluição atmosférica gera um estresse oxidativo pulmonar, deflagra

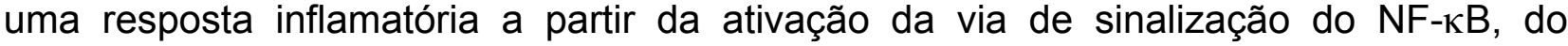
aumento das moléculas de adesão PECAM e ICAM e da sintase de óxido nítrico induzida (iNOS), bem como de citocinas inflamatórias (TNF- $\alpha, \mathrm{IL}-1 \beta, \mathrm{IL}-1 \alpha$, INF- $\gamma, \mathrm{IL}-6$, IL-2, IL-4, MCP-1 e IL-12). Concluímos que na primeira hora de exposição, a corticosterona gerada inicialmente pela introdução do animal a um ambiente desconhecido, a câmara poluída, potencia a síntese de melatonina pela pineal. A medida que o tempo de exposição à poluição progride, a concentração plasmática noturna da melatonina se reduz em 39,0\%, enquanto que a pulmonar aumenta $55,0 \%$. Tanto as enzimas AA-NAT (arilalquilamina-N- acetiltransferase) e ASMT (acetilserotoninametiltransferase) envolvidas na biossíntese da melatonina, quanto as enzimas antioxidantes SOD ( superóxido desmutase), CAT (catalase) e GPx (glutationaperoxidase) tem suas expressões gênicas no pulmão duplicadas dependente do tempo de exposição à poluição. Em relação as enzimas antioxidantes, houve também um aumento nas atividades das mesmas, sendo transiente na SOD e crescente nas demais. O envolvimento da melatonina produzida localmente na resolução do processo inflamatório foi atestado através do bloqueio dos receptores de $M_{1}$ e $M_{2}$ pelo antagonista luzindol, concluindo desta forma que a expressão gênica das enzimas antioxidantes SOD e CAT são moduladas por esta indolamina. A melatonina produzida no pulmão atua de forma autócrina/parácrina regulando o estresse oxidativo via receptores $\mathrm{MT}_{1}$ e $\mathrm{MT}_{2}$. Estes resultados servem de base para investigações futuras de ações farmacológicas que protejam ou mesmo revertam os efeitos lesivos gerados pela poluição atmosférica através do conhecimento do eixo imune-pineal tendo a melatonina ou análogos como agentes terapêuticos.

Palavras-chave : Melatonina. Poluição atmosférica. Material particulado fino. Pulmão. Estresse oxidativo. 


\begin{abstract}
PEREIRA, E. P. Relevance of the immune-pineal axis in rat lung defense response to air pollution 2016. 117 p. Ph. D. thesis (Pharmacology) - Instituto de Ciências Biomédicas, Universidade de São Paulo, São Paulo, 2016.
\end{abstract}

During assembly of an inflammatory response there is a transient switching between the central melatonin production by pineal to peripheral production by defense cells. The same stimulus recognized as a danger signal triggers the suppression of nocturnal melatonin by the pineal and induction of production in immunocompetent cells. These evidences compose the experimental basis of the existence of immune-pineal axis (Markus et al., 2007, 2013). This bidirectional and coordinated communication between the pineal and the immunocompetent cells is important for the efficient assembly and shutdown of an inflammatory response. Air pollution is a major risk factor for urban populations with deleterious effects on health and increased morbidity and mortality. In this in vivo study, we found out that acute exposure to air pollution generates a pulmonary oxidative stress triggers an inflammatory response from the signaling pathway of activation of NF-kB, the increase in adhesion molecules PECAM and ICAM and nitric oxide synthase induced (iNOS) as well as of inflammatory cytokines (TNF- $\alpha, \mathrm{IL}-1 \beta, \mathrm{IL}-1 \alpha$, IFN-y, IL-6, IL-2, IL-4, MCP-1 and IL-12). We conclude that in the first hour of exposure, corticosterone generated initially by the introduction of the animal into an unfamiliar environment, polluted chamber, enhances the synthesis of melatonin by the pineal. As time progresses exposure to pollution, nocturnal plasma melatonin concentration is reduced by $39.0 \%$, while the lung increases $55.0 \%$. Both AA-NAT enzymes (arylalkylamine $\mathrm{N}$-acetyltransferase) and ASMT (acetilserotoninametiltransferase) involved in the biosynthesis of melatonin, as the antioxidant enzymes SOD (superoxide dismutase), CAT (catalase) and GPx (glutationaperoxidase) has its gene expression in lung duplicate dependent on time of exposure to pollution. Regarding the antioxidant enzymes, there was also an increase in the activities of them, transient being in SOD and growing in others. The involvement of melatonin produced locally in the resolution of inflammation was attested by blocking the MT1 and MT2 receptor antagonist by luzindole, concluding in this way that the gene expression of antioxidant enzymes SOD and CAT are modulated by this indolamine. Melatonin produced in the lung acts in an autocrine/paracrine manner regulating oxidative stress via MT1 and MT2 receptors. These results provide the basis for further investigation of pharmacological actions to protect or even reverse the harmful effects caused by air pollution through knowledge of the immune-pineal axis taking melatonin or analogs as therapeutic agents.

Keywords : Melatonin. Atmospheric pollution. Fine particulate matter. Lung. Oxidative stress. 


\section{LISTA DE ILUSTRAÇÕES}

Figura 1 - Eixo imune-pineal.

Figura 2 - Controle da produção circadiana de melatonina.

Figura 3 - Vias de sinalização na biossíntese de melatonina em glândulas pineais de ratos.

Figura 4 - Esquema de funcionamento do impactador virtual.

Figura 5 - Esquema de funcionamento do Concentrador de Partículas Finas Ambientais de Harvard (CPFAH).

Figura 6 - Protocolo experimental noite.

Figura 7 - Protocolo experimental dia.

Figura 8 - Caracterização elementar do material particulado fino $\left(\mathrm{MP}_{2,5}\right)$.

Figura 9 - Geração do estresse oxidativo pelo material particulado fino $\left(\mathrm{MP}_{2,5}\right)$ a partir da quantificação da peroxidação lipídica.

Figura 10 - Geração do processo inflamatório pelo material particulado fino $\left(\mathrm{MP}_{2,5}\right)$ no parênquima pulmonar, coloração por HE.

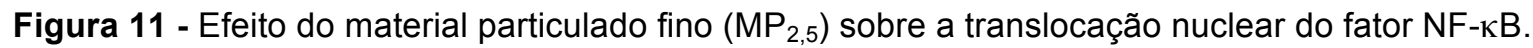

Figura 12 - Efeito do material particulado fino $\left(\mathrm{MP}_{2,5}\right)$ sobre a translocação nuclear de subunidades do fator $\mathrm{NF}-\kappa \mathrm{B}$.

Figura 13 - Efeito do material particulado fino $\left(\mathrm{MP}_{2,5}\right)$ sobre a expressão de moléculas de adesão PECAM1, ICAM-1 e da enzima iNOS em veias pulmonares.

Figura 14 - Efeito do material particulado fino $\left(\mathrm{MP}_{2,5}\right)$ sobre os níveis de citocinas inflamatórias.

Figura 15 - Efeito do material particulado fino $\left(\mathrm{MP}_{2,5}\right)$ sobre a produção de corticosterona e melatonina...68

Figura 16 - O Efeito do material particulado fino $\left(\mathrm{MP}_{2,5}\right)$ sobre a produção da melatonina pela glândula pineal e pulmonar.

Figura 17 - Efeito da exposição ao material particulado fino ( $\mathrm{MP}_{2,5}$ ) na transcrição do RNAm das enzimas AA-NAT e ASMT.

Figura 18 - Efeito da exposição ao material particulado fino (MP ${ }_{2,5}$ ) na transcrição do RNAm das enzimas antioxidantes SOD, CAT e GPx.

Figura 19 - Efeito da exposição ao material particulado fino (MP 2,5 ) na atividade das enzimas antioxidantes SOD, CAT e GPX.

Figura 20 - Efeito da melatonina na expressão gênica das enzimas antioxidantes SOD, CAT e GPx presentes no pulmão após exposição ao material particulado fino ( $\left.\mathrm{MP}_{2,5}\right)$.

Figura 21 - Efeito do luzindol após exposição aguda in vivo ao material particulado fino $\left(\mathrm{MP}_{2,5}\right)$.

Figura 22 - Efeito do material particulado fino $\left(\mathrm{MP}_{2,5}\right)$ após exposição aguda in vivo, em curto, médio e longo prazo. 
Figura 23 - Resumo ilustrativo dos efeitos desencadeados pelo material particulado fino $\left(\mathrm{MP}_{2,5}\right)$ sobre o pulmão e a pineal em modelo in vivo de exposição aguda.

Figura 24 - Esquema ilustrativo do efeito do material particulado fino $\left(\mathrm{MP}_{2,5}\right)$ sobre o pulmão em modelo in vivo de exposição aguda. 


\section{LISTA DE TABELAS}

Tabela 1 - Sequência dos primers utilizados para análise da expressão gênica das enzimas AA-NAT, ASMT, SOD, CAT e GPx. 


\section{LISTA DE ABREVIATURAS E SIGLAS}

5-HT serotonina

5-HTP 5-hidroxitriptofano

AA-NAT arilalquilamina $\mathrm{N}$-acetiltransferase

AAAD descarboxilase de aminoácidos aromáticos

AC

adenililcyclase

AFMK N1-acetil-N2-formil-5-metoxiquinuramina

AMK N1-acetil-5-metoxiquinuramina

AMP monofosfato de adenosina

AMPc monofosfato de adenosina cíclico

AP-1 proteína ativadora 1

ASMT acetilserotoninametiltransferase

ATP adenosina trifosfato

BC black carbon, carbono elementar

$\mathrm{Ca}^{2+} \quad$ lons cálcio

COVs compostos orgânicos voláteis

COX ciclooxigenase

CPFAH concentrador de partículas finas ambientais de Harvard

CRE elemento responsivo a AMPc

CREB proteína de ligação ao elemento responsivo a AMPc

DNA ácido desoxiribonucleico

DAMPS substâncias endógenas associadas ao dano

DEP partículas de exaustão do diesel

DPOC doença pulmonar obstrutiva crônica

EDXRF espectrometria de fluorescência de raios-X por dispersão de energia

ELISA ensaio de imunoadsorção enzimática

EMSA ensaio de eletromobilidade em gel

ERNS espécies reativas de nitrigênio

EROS espécies reativas de oxigênio

g grama

GADPH gliceraldeído-3-fosfato desidrogenase

GM-CSF fator de crescimento de colônias de granulócitos-macrófagos 


\begin{tabular}{|c|c|}
\hline GPCR & receptor acoplado à proteína G \\
\hline GPx & glutationaperoxidase \\
\hline $\mathbf{G R}$ & receptor para glicocorticóide \\
\hline Gs & receptor acoplado à proteína G estimulatório \\
\hline HPA & hidrocarboneto policíclico aromático \\
\hline i.p. & intraperitonial \\
\hline i.v. & intravenoso \\
\hline ICAM & moléculas de adesão intracelular \\
\hline IFN-Y & interferon gama \\
\hline IKB & proteína inibitória kappa B \\
\hline IKK & proteína quinase de IKB \\
\hline IL & Interleucina \\
\hline iNOS & sintase de óxido nítrico induzível \\
\hline $\mathrm{IP}_{3}$ & inositol trifosfato \\
\hline $\mathbf{L}$ & litro \\
\hline LTB-4 & leucotrieno B4 \\
\hline MCP-1 & proteína quimiotática de monócitos-1 \\
\hline mg & miligrama \\
\hline MIA & teste de imunoensaio múltiplo \\
\hline MN & monocuclear \\
\hline MP & material particulado \\
\hline$M P_{0,1} M P_{2,5}$ & material particulado ultrafino, fino e grosso, respectivamente \\
\hline $\mathrm{MP}_{10}$ & \\
\hline NA & noradrenalina \\
\hline NAS & $\mathrm{N}$-acetilserotonina \\
\hline NF-KB & fator nuclear kappa B \\
\hline NOx & óxidos de nitrigênio \\
\hline OMS & Organização Mundial de Saúde \\
\hline PAMPS & padrões moleculares associados aos patógenos \\
\hline P2Y1 & receptor purinérgico do subtipo 1 \\
\hline PBS & tampão fosfato-alcalino \\
\hline PDTC & pirrolidinaditiocarbamato \\
\hline PKA & proteína quinase dependente de AMPc \\
\hline PKC & proteína quinase dependente de cálcio \\
\hline
\end{tabular}


PLC fosfolipase C

PMN polimorfonuclear

PVN núcleos paraventriculares

RNA ácido ribonucléico

ROR/RZR família de receptores nucleares do ácido retinóico

RT-PCR reação em cadeia da polimerase por transcriptase reversa

TBARS substâncias reativas ao ácido tiobarbitúrico

TGI trato gastrointestinal

TPOH triptofanohidroxilase

$\mathbf{m g}$ micrograma 


\section{SUMÁRIO}

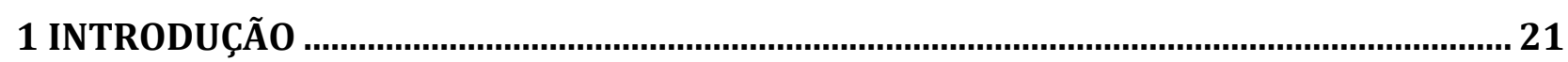

1.1 Poluição atmosférica ......................................................................................... 21

1.1.1 Material particulado (MP) ……................................................................................ 23

1.1.2 Efeitos da poluição atmosférica na saúde humana...........................................................23

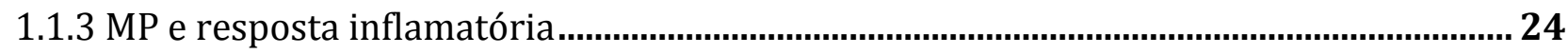

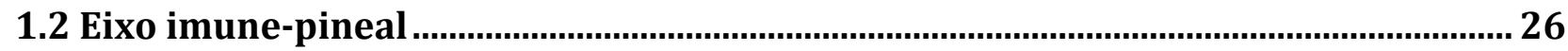

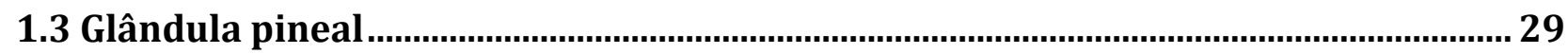

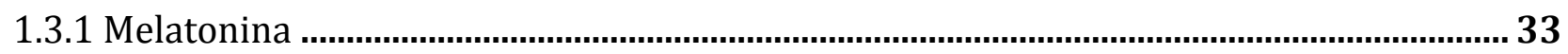

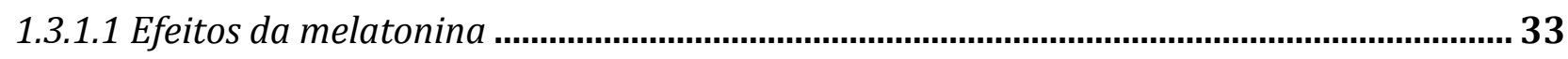

1.3.1.2 Mecanismo de ação da melatonina ..................................................................................37

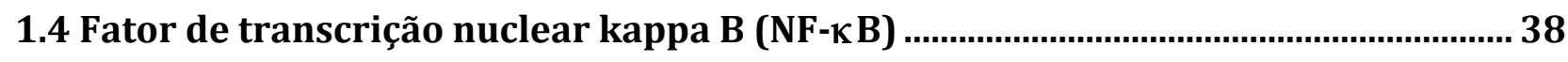

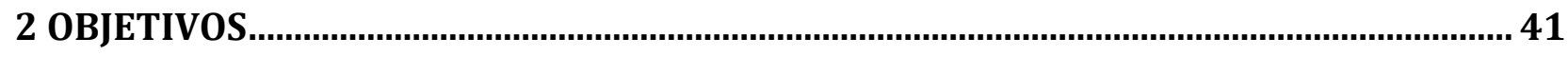

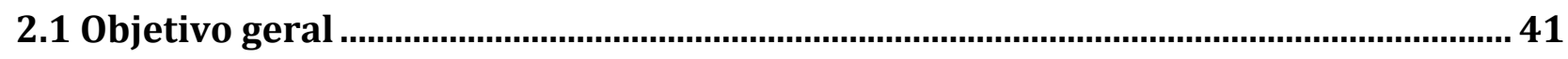

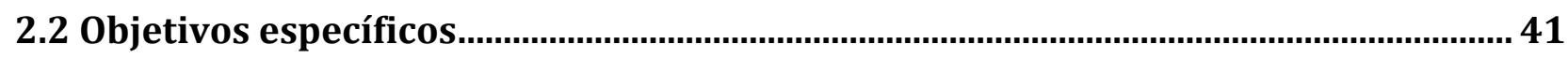

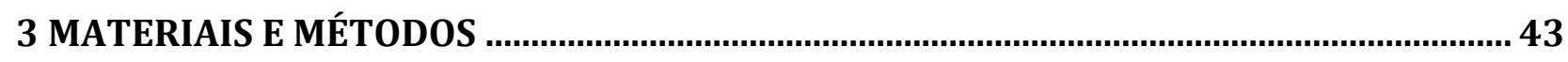

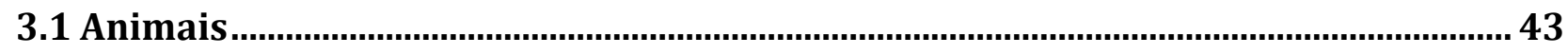

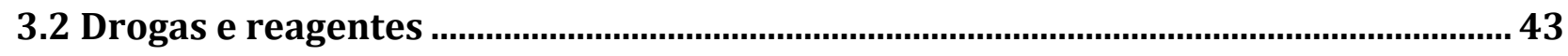

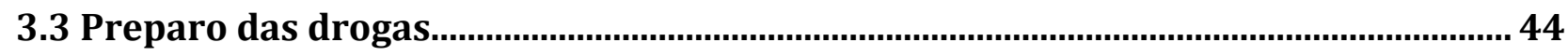

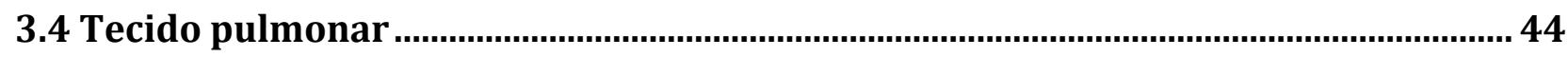

3.5 Concentrador de partículas finas ( $\left.\mathrm{MP}_{2,5}\right)$ ambientais de Harvard (CPFAH) ............. 44

3.6 Condições de exposição .................................................................................................46

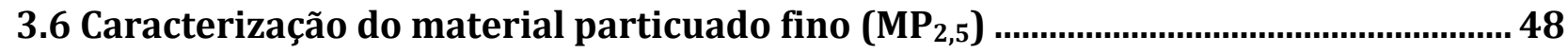

3.6.1 Espectrometria de fluorescência de raios-X por dispersão de energia (EDXRF)............ 48

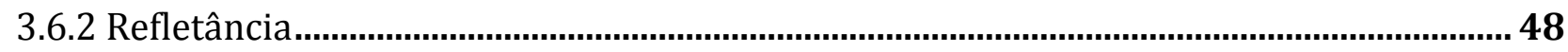

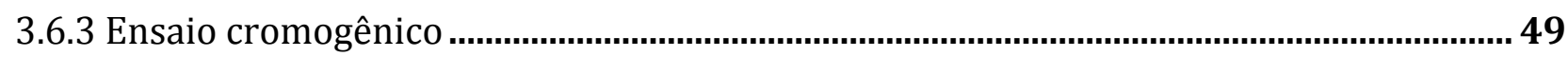

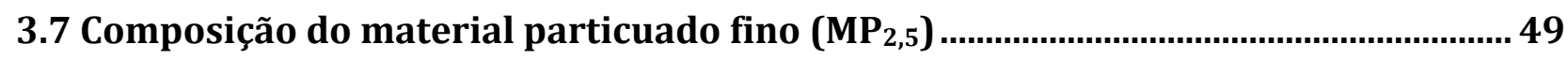

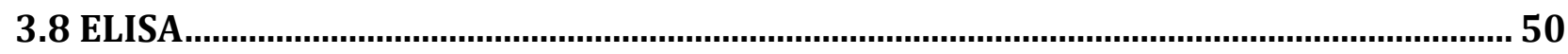

3.9 Ensaio de eletromobilidade em gel (EMSA / gel shift)............................................50

3.10 Ensaio de eletromobilidade em gel (EMSA /super-shift) .....................................51

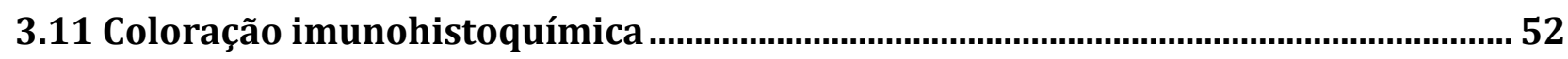

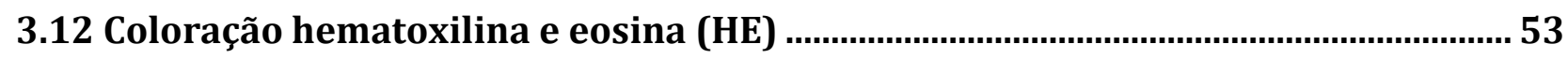

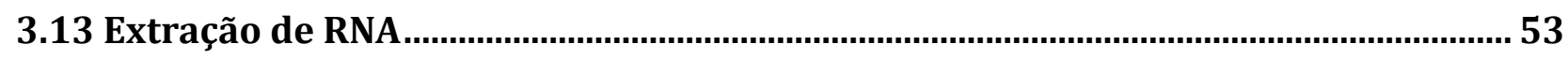


3.14 Análise da expressão gênica por RT-PCR em tempo real 54

3.15 TBARS .55

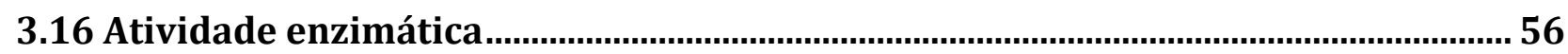

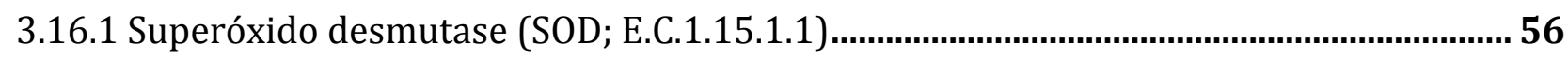

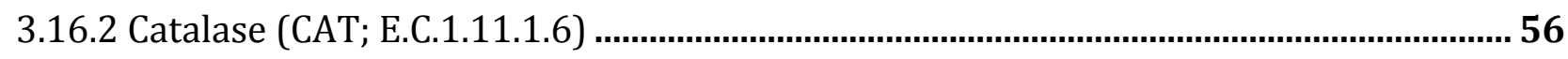

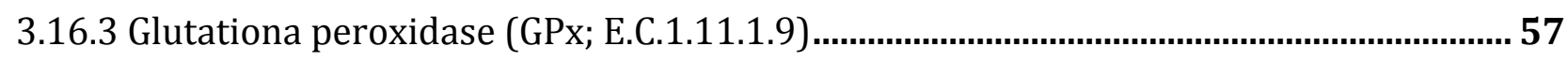

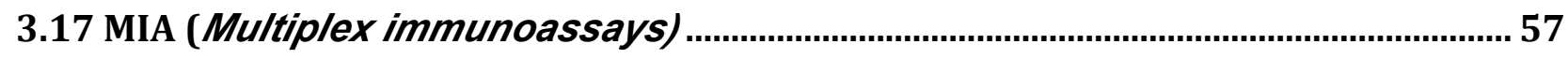

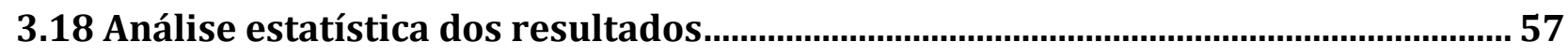

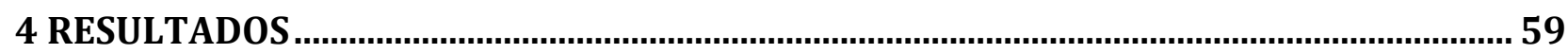

4.1 Caracterização da resposta inflamatória após exposição aguda in vivo ao............ 59

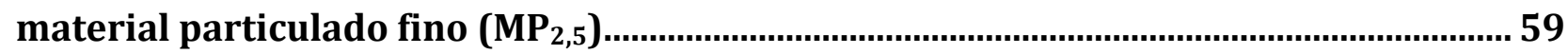

4.1.1 Geração do estresse oxidativo pelo material particulado fino ( $\left.\mathrm{MP}_{2,5}\right)$........................... 59

4.1.2 Inflamação pulmonar pelo material particulado fino $\left(\mathrm{MP}_{2,5}\right)$........................................60

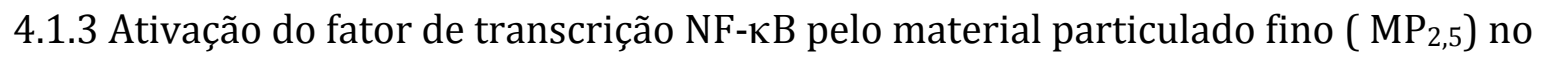
pulmão

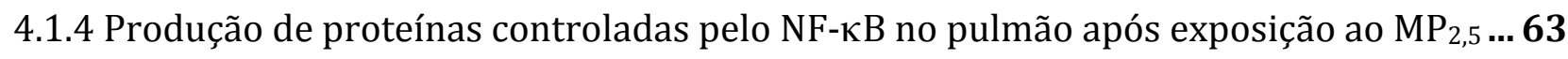

4.1.5 Material particulado fino $\left(\mathrm{MP}_{2,5}\right)$ e os níveis plasmáticos de citocinas. 64

4.2 Efeito do material particulado fino $\left(\mathrm{MP}_{2,5}\right)$ sobre o conteúdo plasmático e pulmonar de melatonina após exposição aguda in vivo. 66

4.2.1 Efeito do material particulado fino $\left(\mathrm{MP}_{2,5}\right)$ sobre a produção de corticosterona e melatonina após exposição aguda in vivo.

4.2.2 Efeito do material particulado fino $\left(\mathrm{MP}_{2,5}\right)$ sobre a produção de melatonina pela pineal e pelo pulmão após exposição aguda in vivo. 68

4.3 Ativação do sistema antioxidante pulmonar após exposição aguda in vivo ao material particulado fino $\left(\mathrm{MP}_{2,5}\right)$..

4.4 Melatonina produzida no pulmão ativa receptores próprios para regular as enzimas oxidantes

4.5 Efeito do luzindol após exposição aguda in vivo ao material particulado fino $\left(\mathrm{MP}_{2,5}\right)$ sobre o estresse oxidativo, sobre a produção de melatonina pela pineal e pelo pulmão

4.6 Efeito do material particulado fino $\left(\mathrm{MP}_{2,5}\right)$ a curto, médio e longo prazo sobre o estresse oxidativo, sobre a produção de melatonina pela pineal e pelo pulmão após

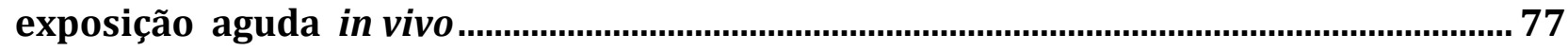

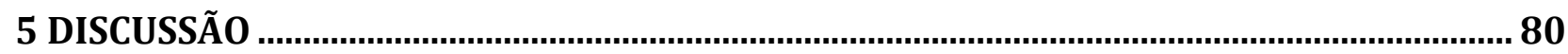

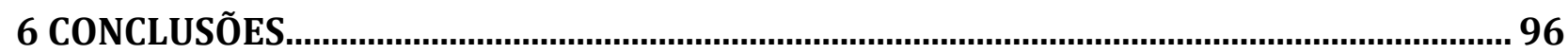

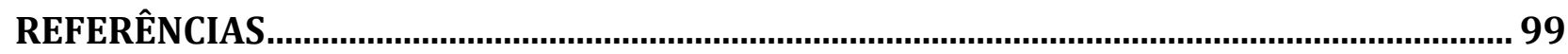


Introdução 


\section{INTRODUÇÃO}

A função cronobiótica da melatonina atuando no ajuste de processos fisiológicos rítmicos ao ciclo claro/escuro ambiental é a sua função mais conhecida, porém as propriedades desta molécula vão muito além dos seus efeitos cronobióticos, apresentando uma grande variedade de ações sendo muitas delas de grande valor terapêutico. A reposta de defesa a um agente agressor é composta por reações sincronizadas entre o sistema nervoso, endócrino e imunológico que permitem a eliminação do agente da injúria e a recuperação do tecido ou organismo. Nesta comunicação temporizada, intersistêmica, a melatonina produzida pela pineal é considerada um mediador da interação neuro-imuno-endócrina (QUAN; BANKS, 2007). A glândula pineal, o hormônio melatonina e os receptores que medeiam as ações desta indolamina compõem o sistema melatonérgico. Estudos recentes têm demostrado que este sistema se encontra alterado frente às diversas moléculas sinalizadoras de injúrias. A poluição do ar é um importante fator de risco para as populações urbanas com efeitos deletérios sobre a saúde e aumento de morbidade e mortalidade, principalmente por doenças cardiovasculares e respiratórias (POPE III et al., 2002; SARNAT et al., 2001; SCHWARTZ, 1994) portanto, ampliar o entendimento pelo qual os contaminantes atmosféricos alteram o sistema melatonérgico e caracterizar a resposta pulmonar frente e este agente é fundamental na criação de alternativas terapêuticas que visam melhorar a saúde pública.

\subsection{Poluição atmosférica}

A história relata episódios eventuais de mortes relacionadas à poluição desde a antiguidade. Poluentes de fontes naturais, como erupções vulcânicas, há muito foram associadas às fatalidades (PÉNARD-MORAND et al., 2004). Foi o século XX, no entanto, um divisor de águas ao concentrar eventos que chamaram a atenção da população geral, dos cientistas e dos governantes para o efeito deletério da poluição sobre a saúde (POPE et al., 2004).

A primeira metade desse século abrigou marcantes episódios associando picos de poluentes do ar com aumento de morbimortalidade: 63 óbitos e milhares de indivíduos com queixas pulmonares no vale do Meuse, na Bélgica, em apenas três dias no início de dezembro de 1930, devido ao nevoeiro com fumaça, smog (DONALDSON et 
al., 2001). Durante os últimos dias de outubro de 1948, em Donora na Pensilvânia, vinte mortes e mais de sete mil pessoas foram hospitalizadas ou ficaram doentes por esta mesma razão. Uma ocorrência de quatro mil e quinhentas mortes em apenas uma semana de dezembro de 1952 causadas pelo big smog na Inglaterra que acabou por estender seus efeitos por meses causando mais de treze mil mortes até março de 1953 (BELL et al., 2001, 2004).

Nas últimas décadas, apesar de não se presenciar eventos de tamanho impacto, a geração de poluentes aumentou de forma exponencial, principalmente nos centros urbanos, tornando a poluição atmosférica um dos maiores fatores de risco à saúde. A Organização Mundial de Saúde (2014) (WHO - WORLD HEALH ORGANIZATION, 2014) estimou que aproximadamente 7 milhões de pessoas morreram em 2012 prematuramente em decorrência de complicações associadas à poluição do ar, confirmando que a poluição atmosférica é atualmente o maior risco de saúde ambiental do mundo. A literatura tem colecionado uma série de evidências epidemiológicas bastante sólidas associando a poluição do ar com efeitos deletérios sobre a saúde e com aumento da mortalidade (KREWSKI et al., 2009). Estes efeitos ocorrem mesmo sob concentrações habituais de poluentes de vários centros urbanos e até o momento, não foram encontrados limites de concentração mínima abaixo dos quais não haja risco à saúde humana (WHO, 2006).

Considera-se ar poluído quando as características naturais da atmosfera são alteradas por agentes químicos, físicos ou biológicos em decorrência da atividade humana ou de fenômenos naturais. Segundo o CONAMA (Conselho Nacional do Meio Ambiente), entende-se como "poluente atmosférico qualquer forma de matéria ou energia com intensidade e em quantidade, concentração, tempo ou características em desacordo com os níveis estabelecidos, e que tornem ou possam tornar o ar: I impróprio, nocivo ou ofensivo à saúde; II - inconveniente ao bem estar público; III danoso aos materiais, à fauna e à flora e IV - prejudicial à segurança, ao uso e gozo da propriedade e às atividades normais da comunidade."(CONAMA, 1990).

A poluição atmosférica é uma mistura complexa formada por materiais de estados físicos variados e de diversas naturezas químicas: gases e material particulado (MP). A fração gasosa é formada por óxidos de enxofre (SOX), monóxido e dióxido de carbono $\left(\mathrm{CO}, \mathrm{CO}_{2}\right)$, ozônio $\left(\mathrm{O}_{3}\right)$, óxidos de nitrogênio ( $\left.\mathrm{NOx}\right)$, compostos orgânicos voláteis (COVs) e os hidrocarbonetos policíclicos aromáticos (HPAs). Atualmente, os HPAs são os mais estudados em decorrência da sua relação com o efeito estufa, o aquecimento 
global e a saúde humana. As partículas sólidas ou líquidas encontradas na atmosfera são denominadas material particulado (MP). A composição do material particulado pode incluir vários elementos químicos, especialmente metais e compostos de carbono (BERGAMASCHI et al., 2007).

\subsubsection{Material particulado (MP)}

O material particulado consiste de uma mistura de partículas sólidas, liquidas ou ambas, suspensas no ar e que agrupa de forma complexa substâncias orgânicas e inorgânicas. Essa mistura heterogênea varia em composição tamanho e origem.

O tamanho do particulado varia de nanômetros a micrômetros. Usualmente esse material é classificado em três categorias: partículas ultrafinas $\left(\mathrm{MP}_{0,1}\right)$, finas $\left(\mathrm{MP}_{2,5}\right)$ e grossas $\left(\mathrm{MP}_{10}\right)$ cujos diâmetros aerodinâmicos são, respectivamente, menores do que $0,1 \mu \mathrm{m}, 2,5 \mu \mathrm{m}$ e $10 \mu \mathrm{m}$ (BROOK et al., 2004).

Uma importante consideração em relação ao tamanho das partículas suspensas no ar é seu alcance no organismo. As partículas grossas penetram principalmente nas vias aéreas superiores, traquéia e brônquios centrais, enquanto que as partículas finas e ultrafinas alcançam as pequenas vias aéreas e podem chegar até os alvéolos, podendo passar para o sistema circulatório (NEMMAR et al., 2001; WICHMANN; PETERS, 2000).

Em geral, as partículas consideradas finas, $\mathrm{MP}_{2,5}$, têm origem principalmente na combustão de materiais fósseis enquanto as partículas grossas, $\mathrm{MP}_{10}$, derivam de fontes naturais como solo e os chamados bioaerosois (endotoxina, grãos de pólen, esporos fúngicos, etc) (BROOK et al., 2004). Poucos autores referem-se às partículas ultrafinas, e sua origem é derivada do processo de combustão, o que inclui a poluição veicular, sendo que o seu tempo de residência na atmosfera é relativamente curto, pois se agregam progressivamente para formar partículas finas (POPE, 2000).

\subsubsection{Efeitos da poluição atmosférica na saúde humana}

Um dos primeiros estudos sobre a correlação existente entre os efeitos da poluição atmosférica à saúde foi estabelecido a partir de episódios agudos de contaminação do ar com a ocorrência de milhares de mortes registradas em Londres, em 1952. No Brasil, jornais das décadas de 60 e especialmente, de 70, notificaram 
registros de episódios agudos de poluição do ar, decorrentes do excesso de poluentes lançados pelas indústrias na atmosfera, causando mal estar e lotando os serviços médicos de emergência (CETESB, 2005).

Desde então, muitos estudos têm demonstrado que a poluição atmosférica prejudica a saúde da população exposta, causando doenças respiratórias (obstrução pulmonar, decréscimo da troca gasosa, inflamação das vias aéreas, exacerbação asmática e brônquica, câncer pulmonar), cardiovasculares (efeito inflamatório sistêmico, alteração na coagulação sanguínea, aumento na aterogênese e morte súbita), cerebrovasculares, além de alguns tipos de câncer, ocupando a terceira posição no ranking mundial de causa mortis (ANDERSON et al., 2012; FAJERSZTAJN et al., 2013; GHIO et al., 2012; HASSAN et al., 2015; POLICHETTI et al., 2009; POPE et al., 2002, 2009; SALDIVA et al. 2013; SAMET et al., 2000; WHO, 2014).

Sabe-se que pessoas que passam longos períodos nas ruas, muitas vezes presas nos congestionamentos, são submetidas a doses maiores de poluentes e ficam mais tempo expostas aos mesmos, tornando-se mais vulneráveis aos seus efeitos adversos (SALDIVA, 2006). Segundo Kampa e Castanas (2008), todos os tipos de poluentes atmosféricos em altas concentrações são prejudiciais à saúde. Porém, um longo tempo de exposição a concentrações baixas de poluentes também pode causar o mesmo dano. Sabe-se também que a toxicicidade do material particulado fino é maior no período noturno na cidade de São Paulo (MARTINS, 2009).

\subsubsection{MP e resposta inflamatória}

Os mecanismos pelos quais o MP age sobre o nosso organismo ainda estão pouco esclarecidos. Algumas teorias admitem que o pulmão seja a porta de entrada de poluentes atmosféricos, a partir do qual uma resposta sistêmica é deflagrada. A primeira hipótese defende que, uma vez depositadas as partículas poluentes no parênquima pulmonar, elas deflagram uma reação inflamatória local que libera mediadores próinflamatórios na circulação sanguínea, provocando uma resposta inflamatória sistêmica (SEATON et al.,1995). Por outro lado, alguns pesquisadores acreditam que haja a translocação de nanopartículas poluentes dos septos alveolares para a circulação sanguínea, sugerindo desta forma um efeito direto nos tecidos-alvo (NEMMAR et al., 2001, 2002). No entanto, este achado ainda não foi consistentemente demonstrado 
(WIEBERT et al. 20006a, 2006b). É possível que os modelos acima citados não sejam excludentes .

Ao longo dos últimos anos crescem as evidências de que ocorre uma resposta inflamatória local após exposição aguda a poluentes, inclusive ao material particulado fino. Saldiva et al. (2002) relataram aumento do número de neutrófilos em lavado broncoalveolar de ratos após inalação aguda de material particulado. Estes achados encontram respaldos no trabalho de Dybdahl et al. (2004) que identificaram aumento no número de macrófagos e neutrófilos em pulmões de camundongos agudamente expostos às partículas de exaustão de diesel. Em acordo com a ativação endotelial que ocorre no pulmão, também ocorre um aumento da concentração plasmática de mediadores da inflamação, tais como: fator de necrose tumoral (TNF- $\alpha$ ), interleucina-6 (IL-6) e leucotrieno B4 (LTB-4), da ativação de fatores de transcrição, geração de espécies reativas assim como a maior produção de moléculas de adesão. Todos estes efeitos podem ser evidenciados mesmo até vinte e quatro horas após a exposição inicial ao material particulado (ARIS et al., 1993; BOUTHILLIER et al., 1998; DONALDSON et al., 2001; GHIO et al., 2000; GURGUEIRA et al., 2002; KELLY et al., 2003; MANTECCA et al., 2009; RIVERO et al., 2005).

O mecanismo de ação pelo qual o material particulado induz respostas inflamatórias segue as mesmas vias que as desencadeadas por microorganismos, envolvendo receptores para padrões moleculares associados aos patógenos (PAMPS) e substâncias endógenas associadas ao dano (DAMPS) (BECKER et al., 2002, 2005; HOLLINGSWORTH et al., 2004; MIYATA; VAN EEDEN, 2011; SHOENFELT et al., 2009; SOUKUP et al., 2001). Os receptores da família Toll-like (TLR) ao reconhecer PAMPS e DAMPS desencadeiam vias de transdução que sinalizam a síntese de mediadores e receptores da resposta inflamatória (KAISHO; AKIRA, 2006).

Os componentes do material particulado são misturas heterogêneas consistindo de elementos inorgânicos (metais), sais, carbonáceos, compostos orgânicos voláteis (COVs), hidrocarbonetos policiclicos aromático (HPAs), materiais biológicos tais como endotoxinas, esporos fúngicos e grãos de polén sendo que alguns deles geram espécies reativas de oxigênio (EROS) e de nitrogênio (ERNS), ativando o sistema imune (ANDERSON et al., 2012; CHIRINO et al., 2010; MERBITZ et al., 2012; MICHAEL et al., 2013). A estimulação dos receptores do tipo TLRs via PAMPS ou DAMPS derivados do MP resulta na ativação de fatores de transcrição como NF-kB e AP1 e 
subsequentemente a liberação de citocinas pró-inflamatórias (IL-1 $\beta$, IL-6, IL-8 e TNF- $\alpha$ ), iniciando e ampliando a resposta inflamatória local e sistêmica (MIYATA; VAN EEDEN, 2011).

\subsection{Eixo imune-pineal}

A percepção da interação entre a melatonina e o sistema imune data da década de vinte, sendo que experimentos posteriores buscavam compreender a função da pineal através de sua extirpação em animais em desenvolvimento. Essas primeiras observações revelaram que órgãos como o timo e glândula adrenal eram os mais afetados em decorrência da pinealectomia cirúrgica (CSABA; BARÁTH, 1975; VAUGHAN; REITER, 1971). De fato, uma grande quantidade de estudos subsequentes confirmaram o papel imunomodulatório da melatonina, mas poucos investigaram a modulação da atividade da pineal em decorrência da ativação do sistema imunológico. A existência dessa modulação foi primeiramente sugerida em um estudo de inflamação crônica em camundongos.

A injeção de BCG (Bacilo Calmette-Guerin) na pata de camundongos gerava um inchaço local cujo tamanho variava de forma rítmica ao longo do dia, estando a pata maior na fase de claro do que na de escuro. O envolvimento da melatonina neste ritmo foi demonstrado pela pinealectomia desses animais. A extirpação da glândula pineal aboliu o ritmo de variação da espessura da pata, enquanto que a reposição de melatonina na água de beber noturna desses animais foi suficiente para restaurá-lo (LOPES et al., 1997). Foi demonstrado, ainda, que a adrenalectomia também abolia o ritmo da espessura da pata e que esse efeito era decorrente de uma diminuição nos níveis circulantes de melatonina (LOPES et al., 2001). Tais resultados permitiram avaliar que a glândula adrenal atuaria como um regulador da função pineal.

A existência de uma comunicação entre as glândulas adrenal e pineal na condição de inflamação foi confirmada e estudos posteriores demonstraram que a corticosterona é capaz de potenciar a síntese de melatonina pela glândula pineal, tanto in vitro quanto in vivo. (FERNANDES et al., 2009; FERREIRA et al., 2005). O aumento nos níveis circulantes de corticosterona em decorrência de estresse moderado também potencia a síntese de melatonina (COUTO-MORAES et al., 2009).

A responsividade da glândula pineal a outras substâncias envolvidas na resposta 
inflamatória também foi investigada. A incubação com TNF- $\alpha$, uma citocina próinflamatória, gera uma supressão da produção de melatonina por inibição da expressão gênica da enzima-chave AA-NAT (FERNANDES et al., 2006). O mesmo efeito inibitório foi observado em pineais incubadas na presença do agente patogênico LPS, lipopolissacarídeo de membrana de bactérias gram-negativas (DA SILVEIRA CRUZMACHADO et al., 2010).

Esta ação inibitória de TNF- $\alpha$ foi corroborada in vivo com um modelo de inflamação em humanos. Mulheres que desenvolveram mastite, um processo inflamatório não infeccioso causado pela sucção durante a amamentação, apresentaram altos níveis circulantes de TNF- $\alpha$ e abolição do ritmo diário de melatonina, sendo este ritmo restaurado somente após a resolução da inflamação, quando os níveis da citocina são zerados (PONTES et al., 2006). Da mesma forma, mulheres submetidas a procedimento cirúrgico de retirada do útero apresentam redução nos níveis plasmáticos noturnos de melatonina no dia da cirurgia, e mesmo quando estes retornam aos valores basais, observa-se que os níveis desse hormônio são menores nas pacientes que apresentam altos níveis de TNF- $\alpha$ (DE OLIVEIRA TATSCH-DIAS et al., 2013). Dessa forma, substâncias anti e pró-inflamatórias (corticosterona e TNF- $\alpha$, respectivamente) apresentam efeitos antagônicos quanto à modulação da atividade biossintética da glândula pineal.

Outros autores já admitiam a hipótese de a glândula pineal receber sinalizações periféricas provenientes do sistema imunológico (SKWARLO-SONTA, 1996, 2003; TSAI et al., 2001), alegando que isso constituiria um mecanismo de retroalimentação relevante para a manutenção da homeostase, já que a melatonina exerce importante papel modulatório nas células imunocompetentes. A análise conjunta dos dados obtidos por nosso grupo permitiu uma compreensão mais profunda acerca dessa relação entre a pineal e o sistema imunológico, acarretando no desenvolvimento do conceito de "eixo imune-pineal" (MARKUS et al., 2007, 2013). As ações antagônicas entre TNF- $\alpha$ e corticosterona, foram as bases iniciais para a compreensão desta relação.

No início da montagem da resposta imune inata, os altos níveis de TNF- $\alpha$ produzidos ou LPS inibem a síntese de melatonina pela pineal. Vale lembrar que, um dos efeitos imunomodulatórios da melatonina em concentrações fisiológicas é o de inibir o rolamento e a adesão de leucócitos sobre a camada endotelial, limitando a migração celular (LOTUFO et al., 2001, 2006). Portanto, a inibição transiente de melatonina circulante na circunstância de uma inflamação pode ser benéfica no sentido de permitir 
uma ativação mais eficaz do sistema imunológico. Concomitantemente, as células imunocompetentes ativadas passam a produzir melatonina em altas concentrações no local, visto que esta indolamina aumenta a capacidade de fagocitose dessas células (MARKUS et al., 2007, 2013; PIRES-LAPA et al., 2013) e que esta molécula reduz o estresse oxidativo, se ligando a radicais livres e também aumentando a expressão de enzimas antioxidantes (ALBARRAN et al., 2001; BARLOW-WALDEN et al., 1995; LIU; NG, 2000; TAN et al., 2010, 2013). Já na fase anti-inflamatória da resposta e com a resolução da inflamação, a síntese pineal de melatonina é restaurada. Isso ocorre tanto pela diminuição na concentração dos fatores inibitórios, quanto pelo aumento da corticosterona circulante, que potencia a atividade biossintética da pineal, conforme figura 3.

Assim, em condições de ativação do sistema imunológico, o mecanismo clássico de regulação da glândula pineal pela informação fótica ambiental deixa de ser predominante e possibilita que a melatonina seja produzida em concentrações e em locais condizentes com as necessidades do organismo. Permitindo desta forma que a resposta imune inata seja eficiente independente da hora do dia até a restauração da higidez do organismo.

A glândula pineal é de fato instrumentada para responder a moléculas ativadoras do sistema imune e relacionadas ao reconhecimento de padrões moleculares associados a patógenos (PAMPS) ou de substâncias endógenas associadas a dano (DAMPS). Os pinealócitos expressam receptores que reconhecem citocinas, como o TNFR (CARVALHO-SOUSA et al., 2011), e receptores da família toll (Toll-like receptors - TLRs), como o TLR4 (DA SILVEIRA CRUZ-MACHADO et al., 2010, 2012). Os TLRs são receptores especializados no reconhecimento de PAMPS, como lipopolissacarídeos de bactérias e RNA viral, e também de algumas substâncias endógenas (DAMPS) como as heat shock proteins, ácidos graxos, lipoproteínas, ácidos nucléicos, glicosaminoglicanos, ATP, dentre outros, que sinalizam a ocorrência de dano celular ou tecidual (BIANCHI, 2007).

Novos estudos vêm sendo desenvolvidos para fortalecer esse conceito. A glândula pineal tem sido amplamente caracterizada quanto aos mecanismos que a torna responsiva às substâncias envolvidas na resposta inflamatória. 


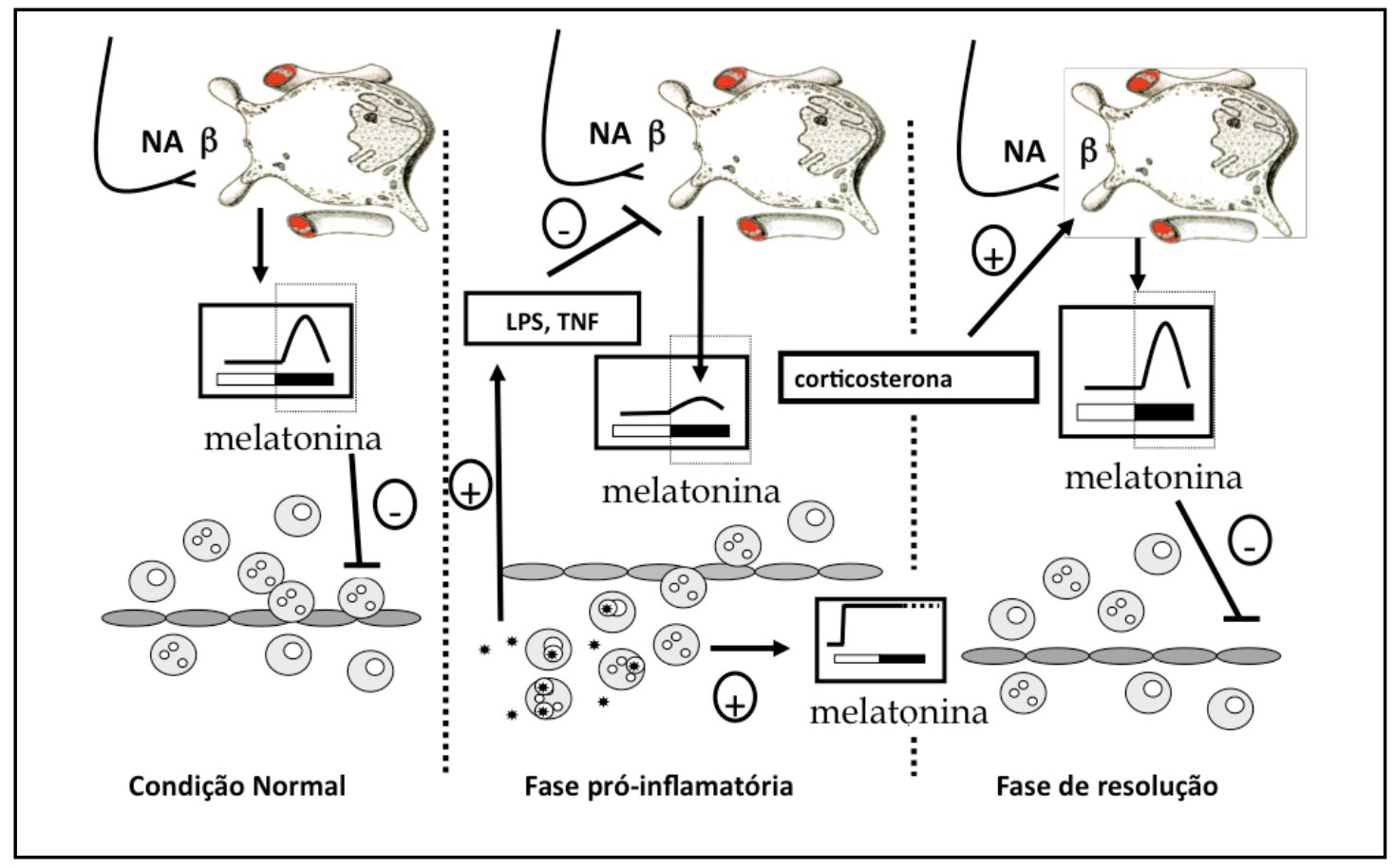

Figura 1 - Eixo imune-pineal. Em condições fisiológicas, a melatonina plasmática noturna exerce efeito inibitório sobre a migração de células imunocompetentes da circulação para os tecidos. Durante uma resposta inflamatória, DAMPS ou PAMPS ativam os receptores TLRs tanto nas células imunocompetentes quanto na glândula pineal, levando a inibição da síntese de melatonina por este órgão e acarretando a sua produção pelas células do sistema imune presentes no local da injúria, que auxilia na resolução da resposta. Caracterizando, portanto a ativação do eixo imune-pineal. Já na fase antiinflamatória, a produção de melatonina pela pineal é restaurada (modificado de MARKUS et al., 2013).

\subsection{Glândula pineal}

A glândula pineal é um transdutor neuroendócrino, capaz de converter sinalizações neurais em endócrinas (AXELROD, 1974). Em humanos, esta glândula está localizada na porção dorsal do tronco cerebral e conectada ao sistema nervoso central por um pedúnculo por onde a glândula recebe a inervação simpática e a vascularização (MØLLER; BAERES, 2002; SIMONNEAUX; RIBELAYGA, 2003). Em roedores, a pineal migra no sentido dorso-caudal e está dividida em uma porção superficial localizada entre os hemisférios cerebrais e o cerebelo (VOLLRATH, 1981). A pineal é um órgão circunventricular (DUVERNOY; RISOLD, 2007; JOHNSON; GROSS, 1993;). Esses órgãos, localizados na linha média do cérebro circundando o terceiro e quarto ventrículo, apresentam características morfológicas que os distinguem do restante do sistema nervoso (HOFER, 1958). Nesta região, a barreira endotelial é mais frouxa devido a ausência de junções oclusivas, apresentando capilares fenestrados (JOHNSON; GROSS, 1993). Essas características permitem a comunicação direta entre o sangue e 
líquor sendo funcionalmente semelhantes aos portões através da barreira hematoencefálica, o que levou a comparação desses órgãos às janelas do cérebro (GROSS, 1987).

Estruturalmente, a glândula pineal de mamíferos é composta por diversos tipos celulares (MØLLER; BAERES, 2002). As células predominantes são as neuroendócrinas, responsáveis pela produção de melatonina e denominadas de pinealócitos e correspondem a acerca de $80 \%$ da constituição da glândula pineal (ARENDT, 1995; EKSTRÖM; MEISSL, 2003). Também estão presentes células gliais, como astrócitos, microglia, oligodendrócitos e células de Schwann (MØLLER; BAERES, 2002); além de células endoteliais, fagócitos perivasculares (PEDERSEN et al., 1993; REITER, 1980; SATO et al., 1996) e neurônios (SCHRÖDER et al., 1990).

O controle neural da síntese de melatonina pela glândula pineal é exercido pelo núcleo supraquiasmático (NSQ), sede do relógio biológico central, através de uma via polissináptica. Em mamíferos, o relógio biológico central é localizado nos núcleos supraquiasmáticos (NSQ) do hipotálamo. Estes núcleos geram um ritmo circadiano com período muito próximo a 24 horas (REPPERT; WEAVER, 2002). Os núcleos supraquiasmáticos têm papel essencial na variação diária da produção de melatonina, gerando o ritmo e propagando a resposta à luz detectada pela retina (KENNAWAY; WRIGHT, 2002; MOORE, 1997). Esta via inicia-se na retina, onde ocorre a conversão da informação fótica em sinais neurais que, por sua vez, são enviados pelo nervo óptico aos núcleos supraquiasmáticos (NSQ) via trato retino-hipotalâmico. Os núcleos supraquiasmáticos (NSQ) projetam-se aos neurônios do núcleo paraventricular (PVN), havendo liberação do neurotransmissor inibitório GABA sincronizadamente à presença de luz ambiental (KALSBEEK et al., 2000). Portanto, é neste ponto que a via sinalizadora à síntese de melatonina é inibida durante a fase de claro.

$\mathrm{Na}$ fase de escuro ambiental, a via que inerva os neurônios do núcleo paraventricular (PVN) é ativada por neurotransmissão glutamatérgica e segue-se ativada à coluna intermediolateral da medula espinal (TECLEMARIAM-MESBAH et al., 1999), onde originam-se os neurônios pré-ganglionares que se projetam ao gânglio cervical superior. Então, os neurônios pós-ganglionares simpáticos inervam diretamente a pineal e há liberação de noradrenalina pelos terminais nervosos no parênquima da glândula, resultando na indução da produção de melatonina (figura 2). 


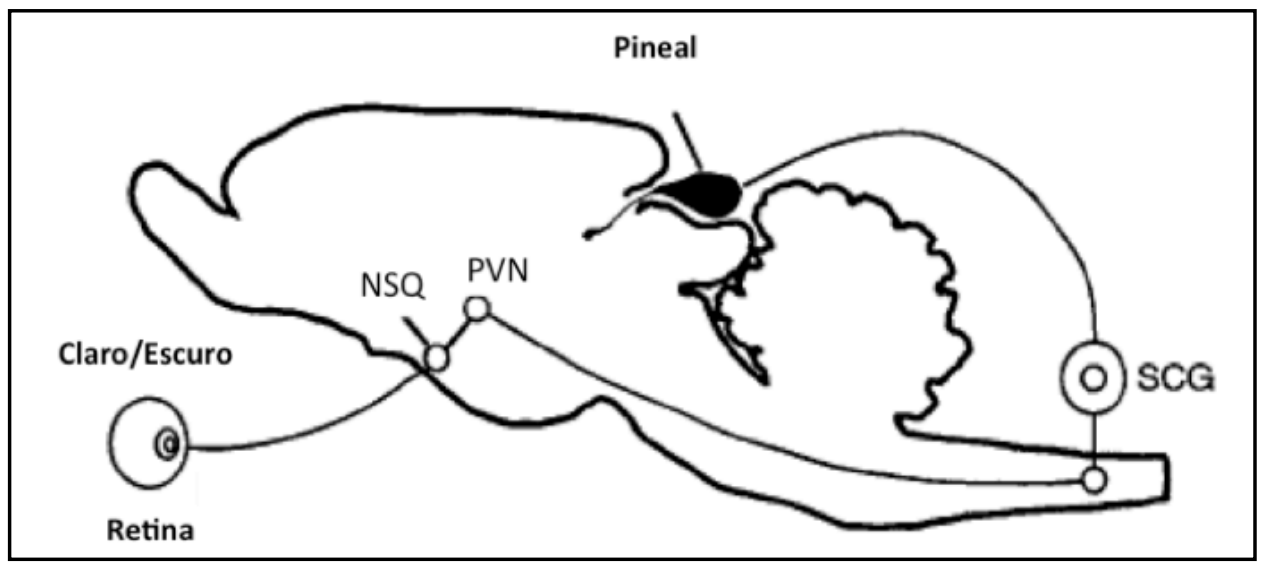

Figura 2 - Controle da produção circadiana de melatonina. Esquema baseado no apresentado por Schultz; Kay (2003) sobre a produção de melatonina em roedores de hábito noturno. A informação fótica ambiental captada pela retina chega aos núcleos supraquiasmáticos (NSQ) pelo trato retino-hipotalâmico e é retransmitida para o núcleo paraventricular do hipotálamo (PVN). O PVN envia então aferências para a coluna intermédio lateral que, via gânglio cervical posterior (SCG), induz a síntese noturna de melatonina.

A noradrenalina liberada pelos terminais simpáticos na fase de escuro atua sobre os adrenoceptores (KLEIN et al., 1983), principalmente do subtipo $\beta 1$, que são receptores acoplados à proteína $\mathrm{G}$ estimulatória (Gs). Quando ativados, as subunidades $\beta$ e $\gamma$ da proteína $G$ se separam da $\alpha$ e, ainda na membrana plasmática, ativam a enzima adenilil ciclase (AC), conversora de AMP (monofosfato de adenosina) em AMP cíclico (AMPc). O aumento citoplasmático deste segundo mensageiro ativa a proteína quinase dependente de AMPc (PKA), responsável pela fosforilação de diversas proteínas, dentre as quais o fator de transcrição CREB (ciclic AMP response element-binding protein). Quando fosforilado, este fator forma homodímeros e liga-se a um coativador, o CBP (CREB-binding protein). Este complexo, por sua vez, liga-se a sequências de DNA específicas presentes na região promotora do gene da enzima arilalquilamina-Nacetiltransferase (AA-NAT) e induz sua transcrição, o que é essencial para completar a via biossintética da melatonina (BALER et al., 1997).

Além dessas sinalizações, a via ainda pode ser potenciada pela ativação de receptores $\alpha 1$-adrenérgicos, pela noradrenalina e receptores $\mathrm{P} 2 \mathrm{Y} 1$ purinérgicos pelo ATP liberado pelos mesmos terminais simpáticos (FERREIRA et al., 1994, 2001). Os adrenoceptores $\alpha 1$ são acoplados à proteína $\mathrm{Gq}$, ativadora da enzima fosfolipase $\mathrm{C}$ que, por uma sequência de eventos, induz aumento de cálcio intracelular $\left(\mathrm{Ca}^{2+}\right)$ e ativação da enzima quinase dependente de cálcio (PKC) (TZAVARA et al., 1996). Essas últimas etapas também são observadas após ativação receptores P2Y1 (FERREIRA et al., 
2003) e a regulação positiva de PKC sobre a enzima adenilil ciclase converge com a sinalização proveniente da ativação $\beta 1$-adrenérgica, aumentando os níveis de AMPc e potenciando a via de sinalização necessária à transcrição de AA-NAT (figura 2).

A síntese de melatonina é iniciada pelo aminoácido triptofano, capturado da corrente sanguínea e hidroxilado a 5-hidroxitriptofano (5-HTP) pela enzima triptofano hidroxilase. Em seguida, o 5-HTP é convertido a serotonina por uma descarboxilase de aminoácidos aromáticos (AAAD). Por sua vez, a serotonina é acetilada pela enzima AANAT à N-acetilserotonina (NAS), que é então metilada pela acetilserotonina metiltransferase (ASMT), formando N-acetil-5-metoxitriptamina, também chamada de melatonina (figura 3) (SIMONNEAUX; RIBELAYGA, 2003).

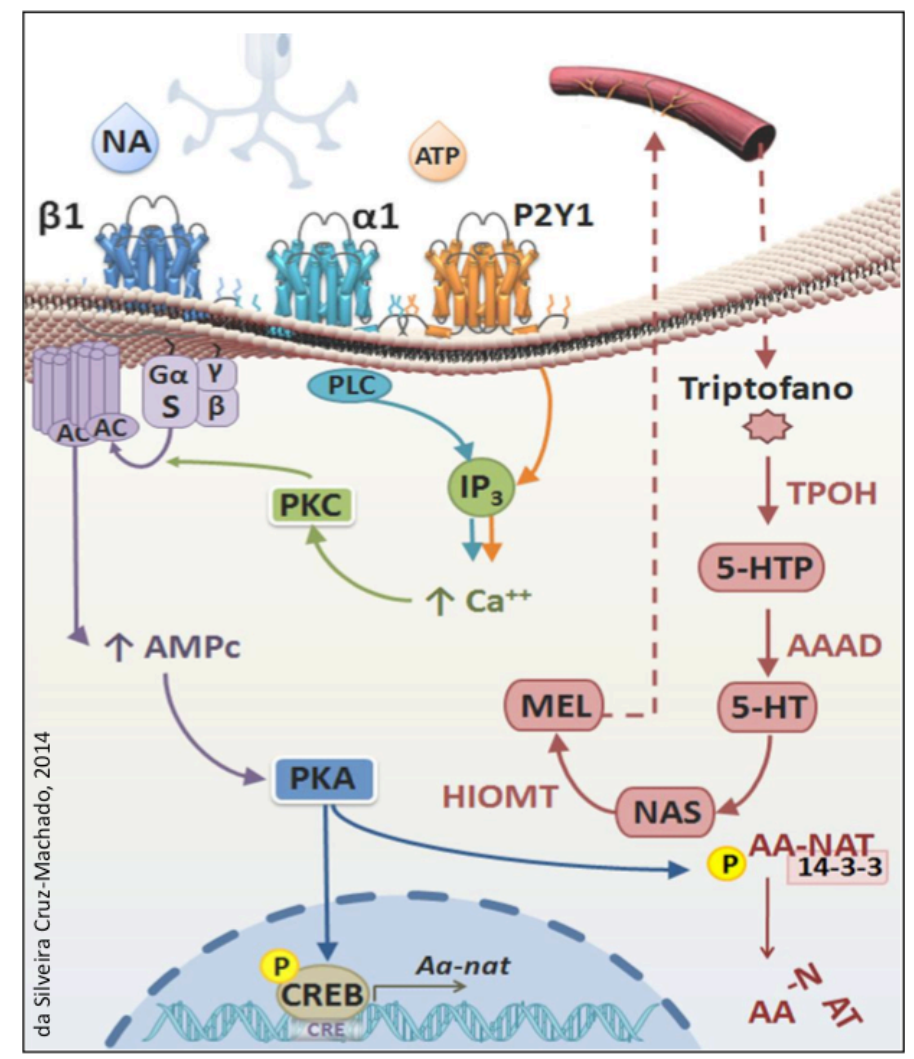

Figura 3 - Vias de sinalização na biossíntese de melatonina em glândulas pineais de ratos. A noradrenalina (NA) liberada noturnamente pelos terminais simpáticos ativa os receptores $\beta$ e $\alpha$ adrenérgicos. Os receptores $\beta 1$ são acoplados à proteína $\mathrm{G}$ estimulatória (s) e sua ativação leva à ativação da enzima adenilil ciclase (AC) pela subunidade $\alpha$ da proteína $\mathrm{G}$. Isso resulta em um aumento nos níveis intracelulares de AMP cíclico (AMPc), ativando PKA, que fosforila CREB, que induz a expressão gênica da enzima AA-NAT. A ativação dos receptores $\alpha 1$-adrenérgicos e P2Y1 purinérgicos induz uma cascata de sinalização que culmina em aumento de cálcio intracelular e ativação de PKC, cujo efeito positivo sobre AC potencia a cascata de sinalização iniciada pelos receptores $\beta 1$. Após a tradução da enzima AA- NAT, sua fosforilação por PKA e ligação à chaperona 14-3-3 estabilizam-na e a tornam ativa, sendo uma enzima-chave para a produção rítmica de melatonina. A síntese de melatonina encontrase esquematizada no canto direito, iniciando com a captura do aminoácido triptofano da circulação. A 
descrição das etapas e das enzimas envolvidas está detalhada no texto. (PLC = fosfolipase C; IP3 = inositol trifosfato; setas tracejadas = simplificação de uma sequência de eventos).

\subsubsection{Melatonina}

A melatonina é uma molécula altamente conservada ao longo da escala filogenética, sendo encontrada desde organismos unicelulares até plantas e vertebrados (PANDI- PERUMAL et al., 2006). Conforme relatado, os primeiros efeitos descobertos da melatonina estão relacionados à sua capacidade em induzir a mudança na coloração da pele de anfíbios (LERNER et al., 1958) e às ações pró ou anti-gonadotróficas, de acordo com a espécie considerada (WURTMAN et al., 1965). A relação deste hormônio com as alterações sazonais observadas no sistema reprodutor de alguns animais logo revelou sua função cronobiótica, como sincronizadora dos ritmos biológicos às variações ambientais.

A melatonina apresenta também diversos outros efeitos que não estão necessariamente relacionados aos ritmos circadianos ou sazonais e são, portanto, classificados como efeitos não-cronobióticos. Além da pineal, outros órgãos também são capazes de produzir melatonina, geralmente de forma não-rítmica e dependente de estímulos específicos. São exemplos de efeitos não-cronobióticos da melatonina suas ações antioxidante, oncostática e imunomodulatória (HARDELAND et al., 2003).

\subsubsection{Efeitos da melatonina}

Em todos os mamíferos, seja de hábito diurno ou noturno, a melatonina é encontrada na corrente sanguínea sinalizando a presença e a duração da fase de escuro ambiental. O primeiro efeito cronobiótico da melatonina foi evidenciado a partir de observações de que a exposição de roedores a diferentes fotoperíodos (relação entre a duração da fase de claro e de escuro) induzia alterações no tamanho e função das gônodas e que a extirpação da glândula pineal e ou administração da melatonina mimetizavam estas alterações (WURTMANN; AXELROD, 1965). A atividade reprodutiva desses animais apresentava variação sazonal bem definida, estabelecia-se, portanto, um dos principais papéis da melatonina, o de sincronizar ritmos endógenos às variações ambientais diárias e anuais, contribuindo para o sistema de temporização interno. Mesmo atuando diretamente em todas as células do organismo, a melatonina também 
exerce seu efeito cronobiótico sobre o próprio núcleo supraquiasmático (NSQ), contribuindo com a sincronização do relógio biológico (PÉVET et al., 2002).

Em mamíferos, além de modular as alterações sazonais relacionadas à reprodução, a melatonina também regula a manifestação de tantos outros ritmos, como o de atividade e repouso, temperatura corporal, pressão arterial e de alterações circadianas e ou sazonais observadas no sistema imune, tais como a proliferação celular na medula óssea e no sistema linfóide (HAUS et al., 1983). Em humanos, a produção dessincronizada de melatonina está relacionada a distúrbios como insônia e mal-estar causados por trabalho noturno ou pelo efeito jet-lag, referente à adaptação a um novo fuso horário em viagens transmeridionais. Estes casos tem sido tratados com sucesso a partir da administração exógena da melatonina (BRZEZINSKI, 1997; PAUL et al., 2010). A melatonina noturna controla os ritmos diários em humanos saudáveis de algumas citocinas como o IFN-y, IL-10 e o IL-2 (ESQUIFINO et al., 2004; LISSONI et al., 1998; PONTES et al., 2007).

A primeira função biológica da melatonina em organismos primitivos unicelulares foi como molécula fotoprotetora contra os danos causados pela exposição à luz. Por ser evolutivamente importante foi conservada por proteger organismos simples contra os danos da oxidação (HARDLAND; FUHRBERG, 1996). Parte das ações antioxidantes da melatonina são mediadas por mecanismos dependentes de receptor, como a sua capacidade em aumentar a expressão e a atividade de enzimas antioxidantes como da superóxido dismutase (SOD), da catalase (CAT) e da glutationa peroxidase (GPx), mas também incluem ações que não dependem dessa interação constituindo da ligação direta às espécies reativas de oxigênio (EROS) e nitrogênio (ERNS)( ALLEGRA et al., 2003; BARLOW-WALDEN et al., 1995; BLANCHARD, et al., 2000; MATUSAK et al., 1997; MAYO et al., 2002; NAIDU et al., 2003; OKATANI et al., 2000; PABLOS et al., 1997; PIERI et al., 1995; RODRIGUEZ et al., 2004; TAN et al., 2000, 1993; TURJANSKI et al., 2000; ZANG et al., 1998).

A melatonina tem propriedades redox devido à presença de um sistema de anel aromático rico em elétrons o que permite à indolamina funcionar como um doador de elétrons (AL-KAZWINI, et al., 1990; JOVANNOVICH; STEENKEN, 1992; POEGGELER et al., 1994). Somando-se a este fato, a presença dos grupos O-metil e $\mathrm{N}$-acetil confere à metatonina a sua propriedade anfifílica. A anfifilicidade é uma peculiaridade química de grande importância, representando uma diferença fundamental e fisiologicamente relevante para a maioria dos limpadores (scavengers) de elementos oxidantes, os quais 
são normalmente hidrofílicos como o ascorbato, o NADPH e a glutationa, ou lipofílicos como o a-tocoferol e carotenoides. Tal qualidade permite que esta indolamina atravesse toda e qualquer membrana e que ainda se mantenha solúvel em grande proporção na fase aquosa.

A melatonina age modulando positivamente a expressão de enzimas antioxidantes via receptores em concentrações fisiológicas (faixa pM-nM) (HARDLAND, 2009; TAN et al., 2002) ou quando em concentrações farmacológicas (faixa $\mu \mathrm{M}-\mathrm{mM}$ ), interage diretamente com radicais livres (MARSHALL et al., 1996; POEGGELER et al., 1996).

Dados acumulados na última década indicam que a melatonina desempenha um papel na defesa antioxidante mitocondrial, preservando a sua homeostase, reduzindo a geração de espécies reativas de oxigênio e nitrogênio, otimizando o fluxo de elétrons e a aumentando a atividade enzimática da cadeia de transporte elétrico (complexo I e IV) consequentemente, aumentando a produção do ATP (ACUÑA-CASTROVIEJO et al., 2011; ENGELBRECHT et al., 2014; LÓPEZ et al., 2009; MARTÍN et al., 2002; NAVARRO-ALARCÓN et al., 2014; PARADIES et al., 2015, 2010).

Um outra virtude da melatonina é que os seus metabólitos, o AFMK (N1-acetil-N2formil-5-metoxiquinuramina) e o AMK (N1-acetil-5-metoxiquinuramina), também são capazes de reagir com espécies reativas de oxigênio e nitrogênio (HARDELAND et al., 2006, 2009; SILVA et al., 2006).

O primeiro relato da correlação entre a melatonina e o sistema imune data de 1926, onde Berman relatou melhora na resistência às doenças infecciosas em gatinhos alimentados por dois anos com extratos de glândulas pineal de touros jovens (CARRILLO-VICO et al., 2013). Posteriormente, esta ligação foi observada a partir de animais pinealectomizados e a redução na sua capacidade imunológica (CSABA; BARATH, 1975).

A propriedade imunomodulatória da melatonina vem sendo bastante explorada. Dados amealhados comprovam que tanto a sua função cronobiótica sobre o sistema imune, quanto a administração exógena e a sua produção extra-pineal modulam os componentes desse sistema (CARRILLO-VICO et al., 2013; MARKUS et al. 2013, 2007; SKWARLO-SONTA et al., 2003). A produção extra-pineal de melatonina ocorre em situações especiais, como na vigência de um quadro inflamatório, tendo sido verificada em diversas células como as epidérmicas, no trato gastrointestinal, na retina e em células imunocompetentes como NK (natural killers), timócitos, linfócitos e macrófagos 
(BÜBENIK; 1997; CONTI et al., 2000; KVETNOY, 1999; MUXEL at al., 2012; PIRESLAPA et al., 2013; PONTES at al., 2006; SLOMINSKI et al., 2005). Estudos realizados com altas concentrações de melatonina, de origem extra-pineal ou exógena, revelaram diversas modulações na resposta imune (CARRILLO-VICO et al., 2005), tais como aumento da proliferação de linfócitos $\mathrm{T}$, da apresentação de antígenos pelos macrófagos e da atividade fagocitária destes (PONTES et al., 2006; MUXEL at al., 2012; PIRESLAPA et al., 2013); aumento na atividade de células do sistema linfóide, do baço e da medula óssea; estimulação da síntese de algumas citocinas, como IL-2, IFN- $\gamma$ e IL-6 (MILLER et al., 2006) e regulação da síntese de óxido nítrico pelas células endoteliais (TAMURA et al., 2009).

Por outro lado, a melatonina em concentrações compatíveis às encontradas no plasma em seu pico noturno parece exercer um efeito antiinflamatório, interferindo no processo de migração celular por inibir o rolamento e adesão de células imunocompetentes sobre a camada endotelial (LOTUFO et al., 2001). Dessa forma, o efeito que a melatonina exerce sobre o sistema imune é dependente de seu local de produção e da quantidade produzida, não podendo ser caracterizada como um hormônio exclusivamente pró ou anti-inflamatório.

A sua ação oncostática está relacionada a suas propriedades anti-proliferativa e anti-angiogênica (BLASK et al., 2005; LISSONI et al., 2001), uma vez que a melatonina inibe ou bloqueia o ciclo celular das células tumorais através da ativação e aumento de genes supressores p21 e p53, além de inibir as vias de sinalização relacionadas à hipóxia que ativam a angiogênese. Uma outra ação é a indução de morte por apoptose (pró- apoptotico) de células tumorais, tais como linfomas, tumores de próstata, mamários e colo-retal (MEDIAVILLA et al., 2010). Estudos clínicos comprovam que o uso apenas da melatonina no tratamento do câncer não é suficiente, porém a mesma utilizada concomitantemente com um medicamento oncológico aumenta significativamente o número de animais sobreviventes, além da regressão de tumores em metástase e dos efeitos colaterais (BLOCK et al., 2008; DI BELLA et al., 2013; JUNG; AHMAD, 2006; LISSONI et al., 1999). Recentemente, Kinker et al. (2016) propôs que o índice ASMT : CYP1B1 (enzimas de síntese e metabolização da melatonina) seja usado como um fator prognóstico em gliomas humanos para avaliar a sua malignidade. 


\subsubsection{Mecanismo de ação da melatonina}

Como a melatonina tem uma variedade de efeitos, ela apresenta, portanto, uma diversidade de mecanismos de ação. A melatonina exerce seus efeitos principalmente pela ligação de alta afinidade com receptores de membrana acoplados à proteína $\mathrm{G}$, mas apresenta também a capacidade de interagir diretamente com proteínas intracelulares, podendo ainda ter uma ligação com os receptores nucleares. No entanto, alguns efeitos da melatonina persistem mesmo na ausência de receptores $M T_{1}$ e $M T_{2}$ ou mesmo com um bloqueio farmacológico dos mesmos indicando um mecanismo independente de receptor.

Diversas ações da melatonina são mediadas por receptores de membrana $\mathrm{MT}_{1} \mathrm{e}$ $\mathrm{MT}_{2}$ (DUBOCOVICH, 1988; 1997; REPPERT et al., 1994, 1995), tendo sido detectados praticamente em todos os tipos celulares de mamíferos (ZLOTOS et al., 2014). Esses receptores pertencem à família de receptores acoplados à proteína $\mathrm{G}$, que contém sete domínios transmembrânicos e são responsáveis principalmente pelos efeitos cronobiológicos. Ambos receptores sinalizam principalmente a via proteína Gi ( inibitória) que induz a redução do segundo mensageiro AMPc através da via AMPc-PKA-CREB ou podem sinalizar por $\mathrm{Gq}$ modificando a atividade da fosfolipase C (PLC), induzindo o aumento dos níveis de cálcio, inositol trifosfato (IP3) e consequentemente a ativação da PKC (BRYDON et al., 1999; LIU et al., 2016, MACKENZIE et al., 2002). Em células mononucleares a indução da expressão das citocinas IL-1 e IL-12 ocorre via ativação de receptores $\mathrm{MT}_{1}$ (CARILLO-VICO et al., 2003), já o aumento da atividade fagocitária induzida por melatonina é mediado por $\mathrm{MT}_{2}$ (PIRES-LAPA et al., 2013).

Um terceiro receptor, inicialmente descrito como $\mathrm{MT}_{3}$ (DUBOCOVICH, 1988) foi caracterizado posteriormente como sendo a enzima quinona redutase II, a qual apresenta baixa afinidade por melatonina e alta por NAS (NOSJEAN et al., 2000). Tal receptor ainda medeia a adesão de leucócitos à camada endotelial, participando do processo de inibição da migração noturna destas células imunocompetentes em ratos (LOTUFO et al., 2001). Recentemente, Cernysiov et al. (2015) mostrou em camundongos que a adesão de granulócitos é suprimida via este mesmo receptor.

Dentre as moléculas intracelulares com as quais a melatonina interage estão a calreticulina, proteínas microtubulares e a calmodulina (BENITEZ-KING, 2006; DE ALMEIDA-PAULA, 2005; PANDI-PERUMAL, 2008) sendo que a ligação com esta última inibe a formação do complexo cálcio $\left(\mathrm{Ca}^{2+}\right)$-calmodulina por consequência impede a 
atividade de enzimas dependentes da formação deste complexo como a adenilil ciclase e enzimas quinases (BENITEZ-KING; ANTÓN-TAY, 1993). A melatonina se liga também aos os receptores nucleares da família do ácido retinóico (ROR 1, ROR 2, RZR , RZR $\beta$ ), que regulam a transcrição de genes alvos. Estes foram identificados como uma classe de receptores envolvidos na sinalização nuclear com efeitos cronobióticos, embora existam dúvidas se o efeito da melatonina sobre estes receptores é direto ou indireto (HARDELAND, 2009),

Por fim, a melatonina interage diretamente com espécies reativas de oxigênio e nitrogênio, a partir da sua doação de elétrons, onde na reação os mesmos são pareados e as cargas elétricas neutralizadas, tal mecanismo lhe confere a característica de um excelente redutor, ou seja, um antioxidante (HARDLAND et al., 1995; POEGGLER et al., 1996; 2002; REITER et al., 1995; TAN et al., 1993).

\subsection{Fator de transcrição nuclear kappa B (NF-кB)}

A via do NF-кB (fator nuclear kappa B) é uma via clássica na mediação da resposta imune inata, sendo que seus principais genes-alvos são aqueles que codificam proteínas relacionadas a respostas inflamatórias, como os de citocinas (TNF- $\alpha$, IL-2, IL6 ) e seus respectivos receptores, moléculas de adesão (VCAM, ICAM), além de enzimas que também participam da resposta imune inata, como a sintase de óxido nítrico induzida (iNOS) e a ciclooxigenase 2 (COX-2) (O'NEILL; KALTSCHMIDT, 2007). Além

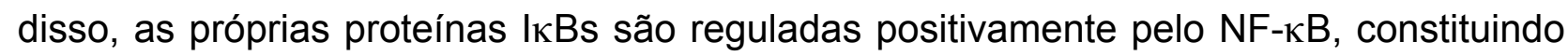
um mecanismos de retroalimentação negativa, essencial para finalizar e limitar a resposta inflamatória (HAYDEN; GHOSH, 2012). De modo geral, a via do NF-kB é classicamente ativada por estímulos imunogênicos, como bactérias e vírus, ou moléculas sinalizadoras como citocinas, sinais apoptóticos, fatores de crescimento, dentre outros (BAEUERLE; BALTIMORE, 1996; TRAENCKNER et al., 1995).

A via de sinalização do NF-кB é central na mediação dos efeitos modulatórios do sistema imune sobre a atividade da pineal, sendo que sua indução por TNF- $\alpha$ ou LPS causa uma inibição na síntese de melatonina, enquanto que o bloqueio da sua translocação nuclear ou da sua ligação ao DNA por corticosterona potencia a atividade biossintética da pineal (CARVALHO-SOUSA et al., 2011; DA SILVEIRA CRUZMACHADO et al., 2010; FERNANDES et al., 2006; FERREIRA et al., 2005). 
Por outro lado, a ativação de outras subunidades de NF-kB nas células imunocompetentes tem efeito oposto sobre este mesmo gene, acarretando em indução da expressão de AA-NAT e, consequentemente, da síntese de melatonina por estas células (MUXEL et al., 2016, 2012). Dessa forma, a via NF-кB é diretamente responsável pela alternância entre a produção pineal e a produção extra pineal de melatonina na presença de um mesmo estímulo patogênico ou inflamatório, como por exemplo a poluição atmosférica.

Em suma, pelo fato da poluição atmosférica atuar por vias notoriamente presentes na glândula pineal e nas células imunocompetentes, neste trabalho, hipotetizamos, que após uma exposição aguda in vivo ao material particulado fino presente neste agente poluente, possivelmente, o sistema melatonérgico, poderia ser alterado e o eixo imune-pineal, ativado. Considerando que o pulmão é o órgão que faz a interface entre o meio externo e o interno do organismo, sendo o principal alvo da poluição atmosférica, investigamos se o mesmo desencadearia uma resposta inflamatória local e sistêmica, sendo ainda capaz de produzir a melatonina em resposta a este agente agressor, avaliando ainda prováveis funções da produção local desta indolamina. 
Objetivos 


\section{OBJETIVOS}

\subsection{Objetivo geral}

O objetivo geral deste projeto foi avaliar a participação do eixo imune-pineal no desencadeamento do processo de defesa em pulmão de ratos normais submetidos à poluição atmosférica urbana de São Paulo.

\subsection{Objetivos específicos}

Verificar se a melatonina é um dos moduladores envolvidos na defesa de pulmões expostos à poluição ambiental. Para tanto foi caracterizada:

- Ativação da resposta imune inata pulmonar via ativação do fator NF-kB, produção de citocinas, migração de células imunocompetentes e geração do estresse oxidativo;

- Variação da concentração de melatonina no plasma e no pulmão;

- Efeitos da melatonina sobre expressão gênica e atividade de enzimas que reduzem o estresse oxidativo, como a superóxido desmutase (SOD), a catalase (CAT) e a glutationa peroxidase (GPx);

- Relevância de receptores acoplados à proteína G nos efeitos da melatonina endógena. 
Materiais e Métodos 


\section{MATERIAIS E MÉTODOS}

\subsection{Animais}

Foram utilizados ratos (Rattus novergiccus) machos da linhagem Wistar de cerca de dois meses de idade. Os animais foram mantidos em ciclo claro-escuro 12:00 h/12:00 h (com luzes acesas às 06:00 horas e apagadas às 18:00 horas), com ração e água ad libitum. O horário de acender as luzes foi considerado o zeitgeber zero (ZT 0). Em todos os experimentos os animais foram eutanasiados por decapitação sem a administração de anestésicos. Este projeto foi realizado sob a licença da Comissão de Ética no Uso de Animais (CEUA) do Instituto de Ciências Biomédicas da Universidade de São Paulo sob o protocolo $n^{\circ}$ 057/2012, em concordância com a regulamentação do Conselho Nacional de Controle de Experimentação Animal (CONCEA).

\subsection{Drogas e reagentes}

As drogas e reagentes utilizados tiveram as seguintes procedências:

- Ácido polideoxinosínico-deoxicitidílico [poli(dldC)] - Sigma-Aldrich; St. Louis, MO, EUA;

- Acrilamida - Bio-Rad; Richmond, CA, EUA;

- Adenosina 5'- trifosfato, $\left[\gamma^{32} \mathrm{P}\right]$ Easy Tides $^{\circledR}$ - Perkin Elmer; Boston, MA, EUA;

- Álcool etílico - Merck; Darmstadt, Alemanha;

- Anticorpo policlonais de coelho anti-subunidades de NF-kB: p50 (sc-114X), p52 (sc-298X), RelA (sc-109X), RelB (sc-226X) e c-Rel (sc-70X) - Santa Cruz Biotechnology; CA, EUA;

- Bisacrilamida (N, N'-metilenebisacrilamida) - Sigma-Aldrich; St. Louis, MO, EUA;

- Ditiotreitol (DTT) - Invitrogen - Life Technologies; Grand Island, NY, EUA;

- Enzima DNase - Invitrogen - Life Technologies; Grand Island, NY, EUA;

- Fenilmetanesulfonilfluorido (PMSF) - Invitrogen - Life Technologies; Grand Island, NY, EUA;

- Luzindol - Sigma-Aldrich; St. Louis, MO, EUA;

- Nonidet-p40 (NP-40) - Calbiochem; Darmstadt, Alemanha;

- Nucleotídeos (mix dNTP) - Invitrogen - Life Technologies; Grand Island, NY, EUA;

- Oligonucletotídeo consenso para NF-кB - Promega; Madison, WI, EUA; 
- Oligonucleotídeos para PCR - Eurofin MWG Operon; Alabama, EUA;

- Paraformoldeído - Merck; Darmstadt, Alemanha;

- Random primers - Invitrogen - Life Technologies; Grand Island, NY, EUA;

- Superscript III - Invitrogen - Life Technologies; Grand Island, NY, EUA;

- SYBR Green PCR mix - Invitrogen - Life Technologies; Grand Island, NY, EUA;

- Trizol - Life Technologies; Grand Island, NY, EUA;

- Xilol - Merck; Darmstadt, Alemanha;

Todos os demais reagentes utilizados apresentavam grau de pureza analítico.

\subsection{Preparo das drogas}

O luzindol foi inicialmente diluído em etanol anidro (100\%) a uma concentração de $10^{-2} \mathrm{M}$ e posteriormente diluído em solução fisiológica a $0,9 \%$ de $\mathrm{NaCl}$ até atingirem as concentrações de $(100,10,3$ e 1) $\mu \mathrm{g} / \mathrm{kg}$. Para o preparo da solução veículo todas etapas foram realizadas da mesma maneira, porém na ausência do antagonista.

\subsection{Tecido pulmonar}

Imediatamente, após a eutanásia, os pulmões foram coletados, acondicionados em criotubos e armazenados em nitrogênio líquido. Para as análises subsequentes, cerca de $150 \mathrm{mg}$ do tecido foram pulverizados em nitrogênio líquido, mecanicamente homogeneizados em $1 \mathrm{~mL}$ de solução salina fosfato (PBS - NaCl $125 \mathrm{mM}, \mathrm{Na}_{2} \mathrm{HPO}_{4}$ $2 \mathrm{mM}, \mathrm{NaH}_{2} \mathrm{PO} 42 \mathrm{mM}$ e KCl $5 \mathrm{mM}$ ) para a análise do estresse oxidativo e em $450 \mu \mathrm{L}$ de $25 \mathrm{mM}$ de Tris- $\mathrm{HCl} \mathrm{pH}-7,4$, contendo $1 \mathrm{mM}$ EDTA e $1 \mathrm{mM}$ de EGTA (adaptado de Pinato et al. 2013) para a deteç̧ão de melatonina. Após a centrifugação (10.000 x g, 10 min, $4^{\circ} \mathrm{C}$ ), os sobrenadantes foram coletados e armazenados a $-80^{\circ} \mathrm{C}$ até o uso.

\subsection{Concentrador de partículas finas $\left(\mathrm{MP}_{2,5}\right)$ ambientais de Harvard (CPFAH)}

O Concentrador de Partículas Finas Ambientais de Harvard (CPFAH), utiliza a tecnologia do impactador virtual e tem o propósito de aumentar em até 30 vezes a concentração das partículas ambientais, iguais e inferiores a 2,5 $\mu \mathrm{m}$ de diâmetro aerodinâmico, em suspensão presentes na atmosfera, sem modificá-las química ou 
fisicamente alimentando uma câmara de exposição para ensaios toxicológicos. O CPFAH utilzado neste projeto está localizado na cidade de São Paulo, entre as ruas Teodoro Sampaio e Dr. Arnaldo.

O CPFAH é formado por um conjunto de impactadores virtuais montados em série, que consistem em um acelerador de fluxo de ar que o dirige para uma passagem estreita e previamente calibrada, enquanto é aplicado perpendicularmente um vácuo de alta intensidade ao fluxo de ar. Dessa maneira, uma porção gasosa do fluxo de ar e parte das partículas ultrafinas de baixa densidade são removidas, e o material particulado fino inalável passa pelo sistema de concentração e segue rumo a câmara de exposição (figura 4) (SIOUTAS et al., 1995, 1997).

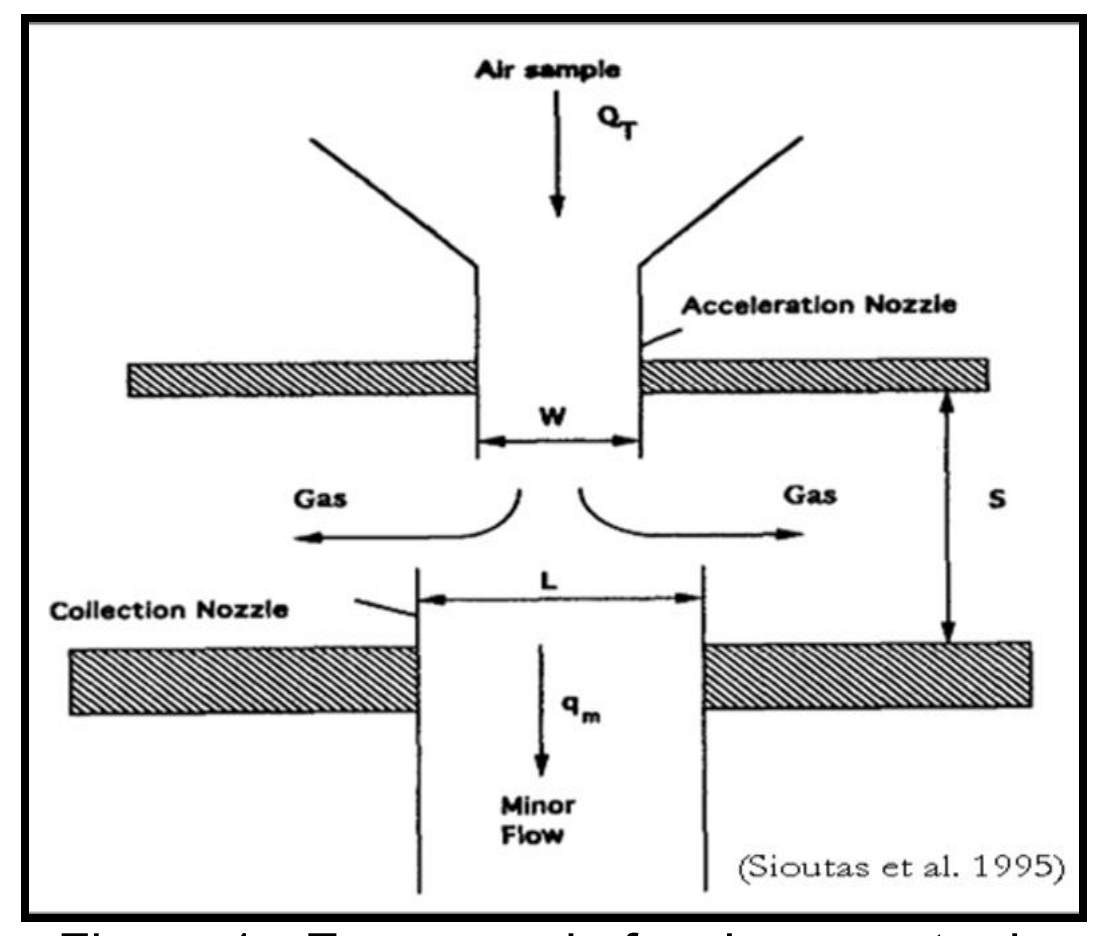

Figura 4 - Esquema de funcionamento do impactador virtual. Cada impactador virtual consiste em um acelerador de vazão que dirige o fluxo de ar na direção de uma passagem estreita e previamente calibrada, enquanto um vácuo de alta intensidade é aplicado perpendicularmente ao fluxo. Dessa maneira uma porção gasosa do fluxo, praticamente sem inércia, e parte das partículas ultrafinas de baixa densidade, são removidas enquanto o material particulado fino inalável passa pelo equipamento, porém acompanhado de uma pequena fração do volume original do ar captado (SIOUTAS et al., 1995, 1997).

Os três conjuntos de impactadores virtuais em série formam 0 concentrador de partículas, cuja vazão inicial de ar atmosférico captada, de 5.000 L/min, 
é reduzida à aproximadamente $40 \mathrm{~L} / \mathrm{min}$. Todo este processo ocorre em fração de segundos, sem qualquer contato do ar com peças móveis, de maneira que não há tempo para alterações das características físicas e da composição química do material particulado (figura 5A). O ar, então carregando uma concentração determinada de partículas finas, alimenta uma câmara onde os animais são expostos (animais poluídos e veículos). Ao mesmo tempo e sob as mesmas condições de pressão, fluxo, temperatura e umidade relativa, outra câmara disposta paralelamente é alimentada com ar filtrado para exposição do grupo controle (animais controle, figura 5B). Já os ratos naives permaneceram em gaiolas de polipropileno por todo o período do experimento. Estas gaiolas ficaram alocadas na sala onde se localiza as câmaras de exposição e controle. Em ambas as câmaras e gaiolas os animais circularam livremente e respiraram naturalmente até o momento da eutanasia.

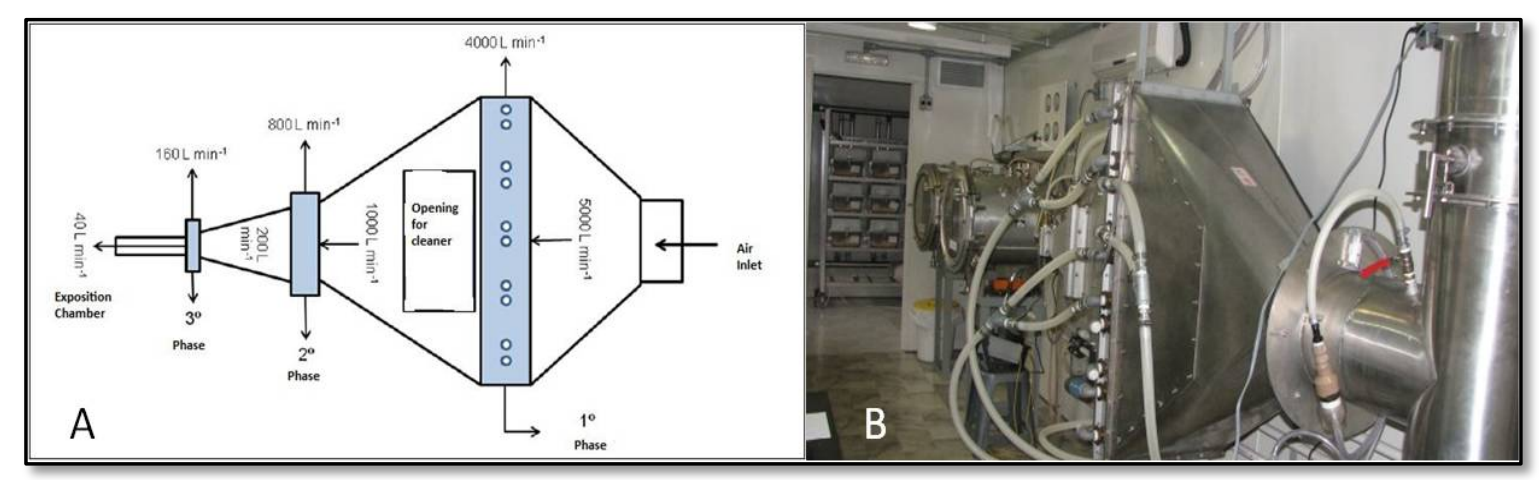

Figura 5 - A - Esquema de funcionamento do Concentrador de Partículas Finas Ambientais de Harvard (CPFAH). A - Esquema de funcionamento: Os três conjuntos de impactadores virtuais estão dispostos em série formando o concentrador de partículas. A vazão inicial de ar captado é de $5.000 \mathrm{~L} / \mathrm{min}$ e a final, dirigida para a câmara de poluição é reduzida à aproximadamente $40 \mathrm{~L} / \mathrm{min}$. B - Vista lateral do CPFAH e das câmaras de ar poluído e filtrado.

\subsection{Condições de exposição}

Durante os experimentos, os animais foram expostos por diferentes tempos ao material particulado fino $\left(\mathrm{MP}_{2,5}\right)$. A quantidade do poluente era diretamente proporcional ao tempo de exposição, sendo que a concentração média variou ao longo dos dias dos experimentos, 666,6 $\pm 94,3 \mu \mathrm{g} \mathrm{MP}_{2,5} / \mathrm{m}^{3}$. A hora de eutanásia dos animais sempre foi a mesma, ou seja, no meio da fase de escuro, ZT18. Durante a noite, os animais foram submetidos às doses agudas de material particulado fino por períodos de uma hora, (início da exposição ZT 17); duas horas (início da exposição ZT 16) e seis horas (início 
da exposição (ZT 12) antes da meia noite (ZT 18) que é o horário do pico de melatonina noturna (figura 6).

Durante o dia, os mesmos foram expostos por uma hora (início da exposição ZT 10) e seis horas (início da exposição ZT 5) até às 17:00 horas (ZT 11), uma hora antes do apagar das luzes. Após a conclusão do tempo de exposição os animais foram eutanasiados (ZT 11) por decapitação tendo seus sangues e os pulmões coletados para este estudo (figura 7).

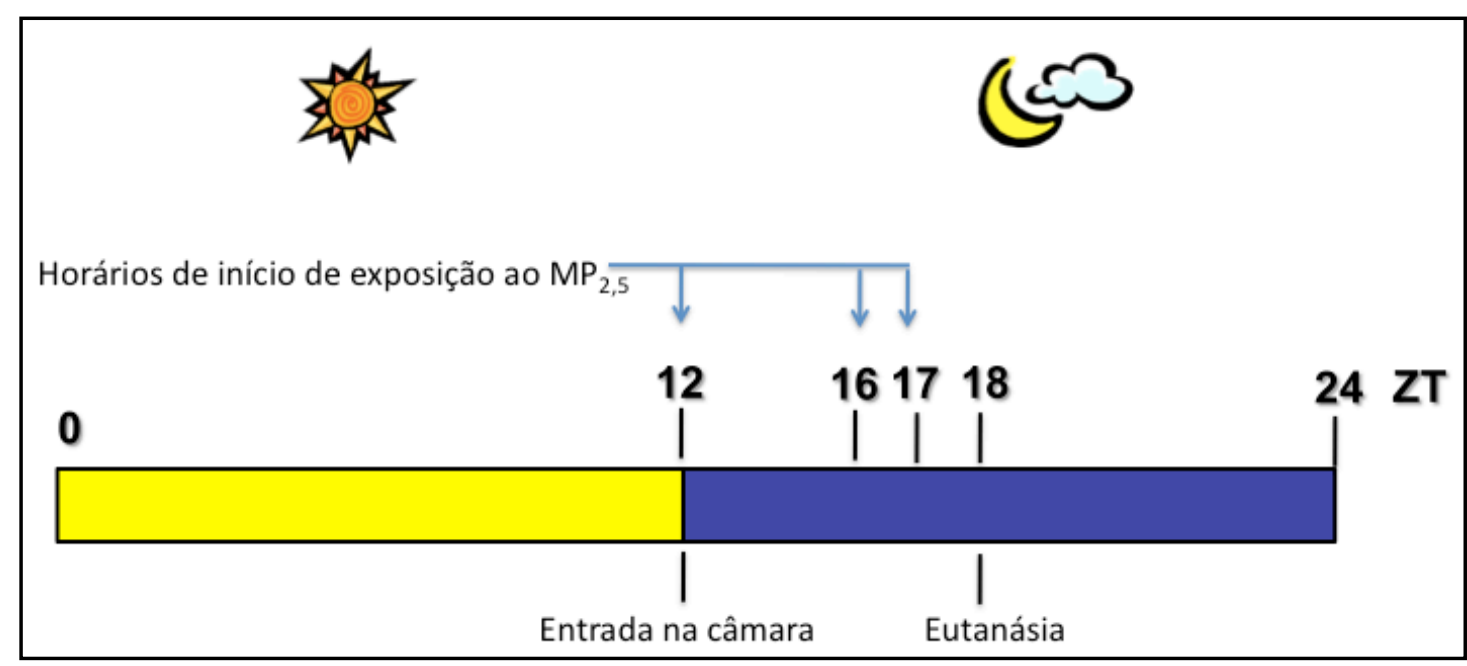

Figura 6 - Protocolo experimental noite. Ratos machos foram divididos em 3 grupos: naive, controle (1,2 e 6 h), poluído (1,2 e 6h) e veículo (6h). O grupo naive não recebeu tratamento, animais controle, poluído e veículo entram nas câmaras de exposição, o primeiro recebeu ar limpo e o segundo e o terceiro inalaram o material particulado proveniente do ar da atmosfera local. Todos os animais entram na câmara no mesmo horário (ZT12) e foram sacrificados no ZT 18. Diferentes tempos de exposição foram realizados, 1 , 2 e $6 \mathrm{~h}$ antes do ZT 18. Para cada tempo de exposição à poluição tem-se um grupo controle referente ao horário. Zeitgeber time - ZT zero corresponde ao momento do ascender das luzes 06:00 horas.

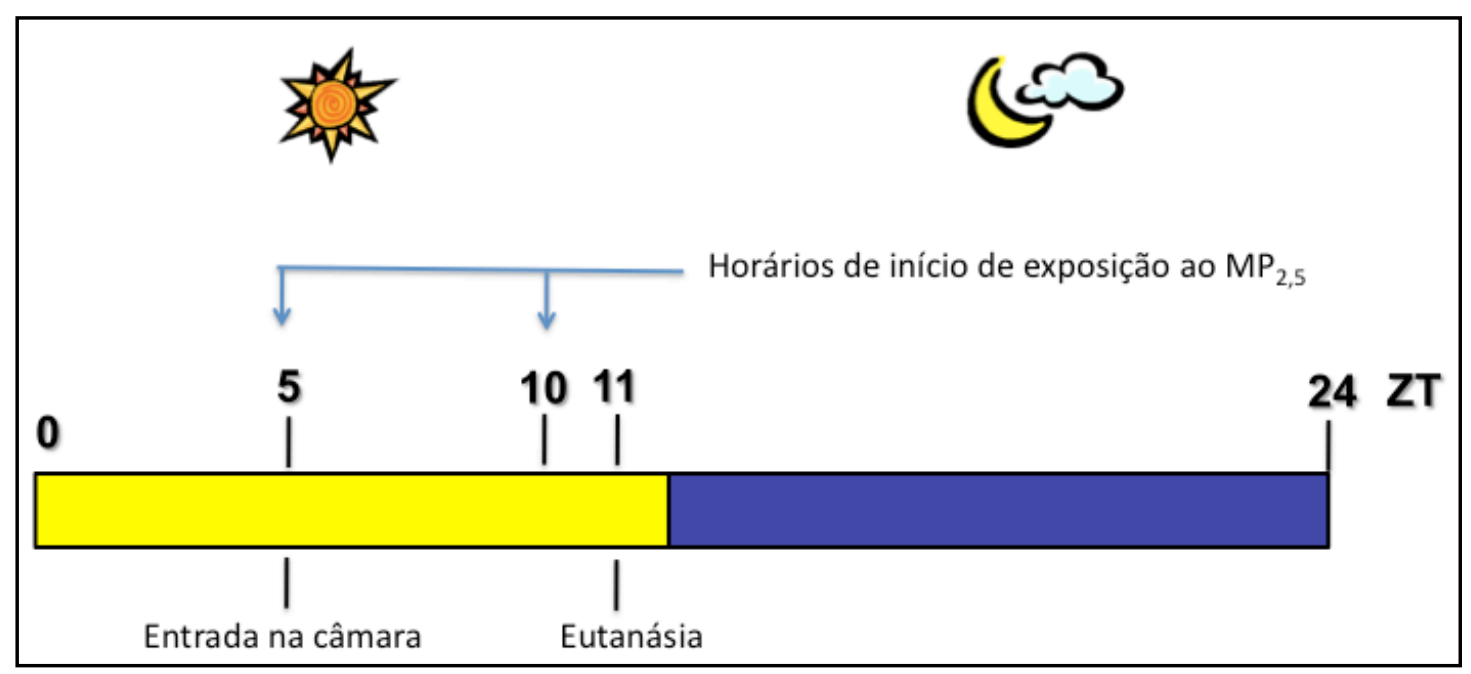

Figura 7 - Protocolo experimental dia. Ratos machos foram divididos em 3 grupos: naive, controle (1 e $6 \mathrm{~h})$ e poluído (1 e $6 \mathrm{~h})$. O grupo naive não recebeu tratamento, animais controle e poluído entram nas câmaras de exposição, o primeiro recebeu ar limpo e o segundo inalou o material particulado proveniente do ar da atmosfera local. Todos os animais entram na câmara no mesmo horário (ZT5) e foram 
sacrificados no ZT 11. Diferentes tempos de exposição foram realizados, 1 e $6 \mathrm{~h}$ antes do ZT 11. Para cada tempo de exposição à poluição tem-se um grupo controle referente ao horário. Zeitgeber time - ZT zero corresponde ao momento do ascender das luzes 06:00 horas.

\subsection{Caracterização do material particuado fino $\left(\mathrm{MP}_{2,5}\right)$}

O material particulado fino aos quais os animais presentes na câmara poluída foram expostos também foram amostrados em filtros de policarbonato (Millipore $®$, com $37 \mathrm{~mm}$ de diâmetro, e 0,8 $\mu \mathrm{m}$ de porosidade) por um período de 60 minutos sob uma vazão de $5 \mathrm{~L} / \mathrm{h}$ e posteriormente analisadas quanto a presença de alumínio (Al), bromo $(\mathrm{Br})$, cálcio $(\mathrm{Ca})$, cloro $(\mathrm{Cl})$, cromo $(\mathrm{Cr})$, cobre $(\mathrm{Cu})$, ferro $(\mathrm{Fe})$, potássio $(\mathrm{K})$, magnésio $(\mathrm{Mg})$, manganês $(\mathrm{Mn})$, níquel $(\mathrm{Ni})$, fósforo $(\mathrm{P})$, chumbo(Pb), enxofre $(\mathrm{S})$, selenio $(\mathrm{Se})$, silício $(\mathrm{Si})$, titânio(Ti), vanádio( $\mathrm{V})$ e zinco $(\mathrm{Zn}$ ) além do carbono elementar (Black Carbon $-\mathrm{BC}$ ) e endotoxinas.

\subsubsection{Espectrometria de fluorescência de raios-X por dispersão de energia (EDXRF)}

A metodologia da espectrometria de fluorescência de raios-X por dispersão de energia (EDXRF) foi utilizada na caracterização elementar do material particulado fino. A espectrometria de fluorescência de raios- $X$ consiste na medida das intensidades do mesmo emitido pelos elementos químicos da amostra. Esta técnica tem sido amplamente utilizada na análise de amostras de plantas e materiais particulados (CHU et al. 2003; RICHARDSON et al., 1995; STEPHENS; CALDER, 2004) e também foi a técnica utilizada neste estudo. Estas medidas foram realizadas em parceria com o Instituto de Astronomia, Geofísica e Ciências Atmosféricas da Universidade de São Paulo (IAG-USP), conforme Yamasoe (1994).

\subsubsection{Refletância}

A técnica de refletância consiste na incidência de luz de uma lâmpada de Tungstênio no filtro amostrado, que reflete uma intensidade inversamente proporcional à quantidade de carbono elementar (BC) presente (YAMASOE,1994). Como as partículas de $B C$ são boas absorvedoras de luz, quanto maior a sua presença, menor a intensidade 
de luz refletida pelo filtro e menor a detectada pelo fotosensor. Estas medidas também foram realizadas em parceria com o Instituto de Astronomia, Geofísica e Ciências Atmosféricas da Universidade de São Paulo (IAG-USP), conforme Yamasoe (1994).

\subsubsection{Ensaio cromogênico}

A fim de verificar a qualidade biológica do material particulado, foi realizado um ensaio espectrofotométrico para endotoxinas adotando um kit comercial (Chromogenic LAL Endotoxin Assay Kit - cat. L00350 - GenScript; NJ, USA ) e seguiu-se as instruções do fabricante.

\subsection{Composição do material particuado fino $\left(\mathrm{MP}_{2,5}\right)$}

A análise elementar do material particulado fino constatou a presença de alumínio $(\mathrm{Al})$, bromo $(\mathrm{Br})$, cálcio $(\mathrm{Ca})$, cloro $(\mathrm{Cl})$, cromo $(\mathrm{Cr})$, cobre $(\mathrm{Cu})$, ferro $(\mathrm{Fe})$, potássio $(\mathrm{K})$, magnésio $(\mathrm{Mg})$, manganêsv $(\mathrm{Mn})$, níquel $(\mathrm{Ni})$, fósforo $(\mathrm{P})$, chumbov $(\mathrm{Pb})$, enxofre (S), selenio (Se), silício (Si), titânio (Ti), vanádio $(\mathrm{V})$ e zinco $(\mathrm{Zn})$ além do carbono elementar (Black Carbon-BC). O material particulado inalado pelos animais presentes na câmara poluída foi composto por poluentes resultantes da ressuspensão de elementos presentes no solo e principalmente pela queima de combustíveis veiculares fósseis, com grande participação do elemento carbono, mais conhecido como o black carbon. Já a quantificação de endotoxina ficou em 0,975 EU/mg de material particulado fino. Portanto, dos compostos quantificados estes foram inalados pelos animais, oriundos da emissão veicular além de fontes não antropogênicas. 


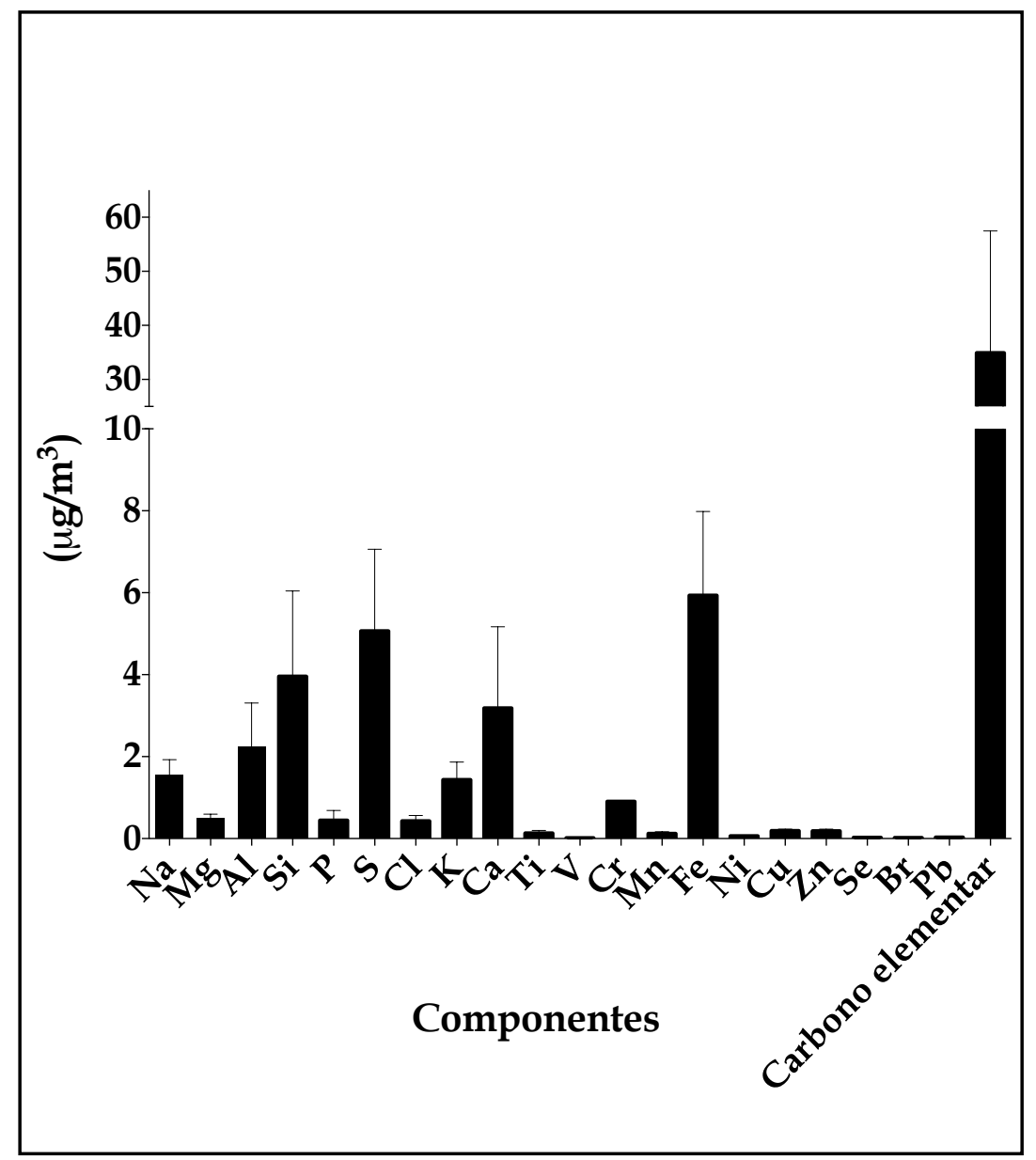

Figura 8 - Caracterização elementar do material particulado fino $\left(\mathrm{MP}_{2,5}\right)$. Valores obtidos a partir da amostragem de 19 filtros. Concentrações de $\mathrm{Na}, \mathrm{Mg}, \mathrm{Al}, \mathrm{Si}, \mathrm{O}, \mathrm{S}, \mathrm{Cl}, \mathrm{K}, \mathrm{Ca}, \mathrm{Ti}, \mathrm{V}, \mathrm{Cr}, \mathrm{Mn}, \mathrm{Fe}, \mathrm{Ni}, \mathrm{Cu}, \mathrm{Zn}$, $\mathrm{Se}, \mathrm{Br}, \mathrm{Pb}$ e carbono elementar (Black carbon) $\left(\mu \mathrm{g} / \mathrm{m}^{3}\right)$.

\subsection{ELISA}

Tanto as concentrações da melatonina plasmática quanto pulmonar e as de cortocosterona foram determinadas pela técnica de ELISA (Enzyme-linked immunosorbent assay), utilizando-se kits comerciais (melatonina - cat RE54021; corticosterona - cat RE52211, IBL Internacional, Hamburg, DE), de acordo com as instruções do fabricante.

\subsection{Ensaio de eletromobilidade em gel (EMSA / gel shift)}

O conteúdo nuclear de NF-кB foi analizado em pulmões de ratos submetidos à poluição e controle em tempos variados. Após os tratamentos, os pulmões foram 
processadas para extração de proteínas nucleares, sendo homogeneizados e incubados em tampão de lise celular (HEPES $10 \mathrm{mM}, \mathrm{KCl} 10 \mathrm{mM}$, EDTA $0.1 \mathrm{mM} \mathrm{pH} \mathrm{8,0,} \mathrm{glicerol}$ 10\%, NP40 0.1\%, DTT $1 \mathrm{mM}$ e PMSF $0.1 \mathrm{mM} ; 15 \mathrm{~min}, 4^{\circ} \mathrm{C}$ ). Após centrifugação (12000 $\mathrm{x}$ g; $1 \mathrm{~min} ; 4^{\circ} \mathrm{C}$ ), o sobrenadante foi descartado e o precipitado foi ressuspendido em 50 $\mu$ l do mesmo tampão de lise, sendo então submetido a nova centrifugação (12000 x g; 1 $\min ; 4^{\circ} \mathrm{C}$ ). Em seguida, o precipitado foi ressuspendido e incubado em $100 \mu \mathrm{l}$ de tampão de extração nuclear (HEPES 10 mM, KCl 0,5 M, EDTA 1 mM pH 8,0; glicerol 10\%, DTT $1 \mathrm{mM}$ e PMSF 0,1 mM; $15 \mathrm{~min}, 4^{\circ} \mathrm{C}$, sob agitação). Após centrifugação (20000 x g; 5 min; $4{ }^{\circ} \mathrm{C}$ ), o sobrenadante contendo o extrato proteico nuclear foi coletado $\mathrm{e}$ armazenado a - $80{ }^{\circ} \mathrm{C}$ até seu uso no ensaio de gel-shift. O conteúdo de proteína foi quantificado pelo espectrofotômetro Nanodrop ND-1000 a 280 nm (Nanodrop, Wilmington, DE, EUA). Cerca de $6 \mu \mathrm{g}$ de proteína nuclear de cada amostra foram incubados em tampão de ensaio (Tris- $\mathrm{HCl} 10 \mathrm{mM} \mathrm{pH} \mathrm{7,5,} \mathrm{MgCl2} 1$ mM, NaCl 50 mM, DTT $0.5 \mathrm{mM}$, EDTA $0.5 \mathrm{mM} \mathrm{pH} 8,0,4 \%$ glicerol, $1 \mu \mathrm{g}$ de poli-dldC) com sonda de oligonucleotídeo dupla fita de sequência consenso a NF-кB (5'AGTTGAGGGGACTTTCCCAGGC-3'), previamente marcada com fósforo radioativo $\left[\gamma^{32}\right.$ P]-ATP (de 25000 a 40000 c.p.m.) pela atividade da enzima T4 quinase. O complexo DNA-proteína foi analisado por eletroforese (a $150 \mathrm{~V}, 1 \mathrm{~h} 30 \mathrm{~min}$ ) em gel nãodesnaturante de poliacrilamida 6\% (acrilamida:bisacrilamida, 37.5:1) em tampão Trisborato/EDTA (TBE 0,25 x). Após a eletroforese o gel foi seco a vácuo (Gel Dryer Vacuum System - Fisher Biotech, Wembley, Austrália), exposto ao filme XAR-5 (Kodak - Rochester, NY, EUA) por $48 \mathrm{~h}$ a $-80^{\circ} \mathrm{C}$. O filme foi então revelado por imersão em solução reveladora (Kodak; $5 \mathrm{~min}$ ) e fixadora (Kodak; $10 \mathrm{~min}$ ) e os complexos de proteína-DNA foram quantificados densitometricamente utilizando o programa ImageJ (Image Processing and Analysis in Java, www.imagej.nih.gov).

\subsection{Ensaio de eletromobilidade em gel (EMSA /super-shift)}

As subunidades de NF-kB presentes em extratos nucleares dos pulmões foram identificadas através do ensaio de EMSA, descrita no item anterior 3.9 com a inclusão de uma etapa. Neste ensaio foram adcionados aos extratos protéicos, $2 \mu \mathrm{g} / \mathrm{mL}$ de anticorpos específicos para cada subunidade de NF-kB (RelA, p50, p52, c-Rel, RelB e 
Bcl3) por 45 minutos a temperatura ambiente antes da incubaçãoo dos extratos com a sonda consenso para NF- $\mathrm{KB}-{ }^{32} \mathrm{P}$. As etapas seguintes também seguiram o protocolo descrito anteriormente.

\subsection{Coloração imunohistoquímica}

Os pulmões foram envolvidos em solução de paraformoldeído 4\% /PBS por vinte e quatro horas. Após este período a solução foi trocada por álcool etílico $70 \%$ e armazenada a $4{ }^{\circ} \mathrm{C}$ até o uso. Na preparação das lâminas, os tecidos foram lavados em gradientes de concentração de álcool etílico (96\% e 100\%) por três vezes em cada e por um período de trinta minutos. A lavagem continuou em solução de xilol $(50 \%, 70 \%$ e $100 \%)$ por quinze minutos cada. Os tecidos foram então inseridos em parafina líquida, esfriados, cortados em Micrótomo em secções de $5 \mu \mathrm{m}$ e fixados em lâminas.

Para a reação de imunohistoquímica, os cortes foram desparafinados, hidratados e submetidos a uma solução de peróxido de hidrogênio $3 \%$ por 20 minutos com o objetivo de inibir a ação de peroxidase endógena. Os cortes foram incubados em solução de glicina, seguido de solução de bloqueio (3\% albumina e 0,01\% saponina em PBS) por 1 hora. Após o bloqueio de reação não inespecífica foi utilizado o Kit avidina/biotina(cat SP-200,Vector Laboratórios; CA,EUA) para também bloquear sítios de biotina. A seguir, foram lavados em PBS. Os cortes foram, então incubados com o anticorpo primário (anti-PECAM-1 (CD31) - anticorpo policlonal de cabra sc-1506, Santa Cruz Biotecnologia; CA, EUA; anti-ICAM-1 (CD54) - anticorpo policlonal de camundongo sc-8439, Santa Cruz Biotecnologia; CA, EUA; anti-iNOS - anticorpo policlonal de coelho cb-3523, Cambridge, UK; nas concentrações de 1:200, 1:100, 1:50, respectivamente) overnight a $4^{\circ} \mathrm{C}$ em câmara úmida. Os cortes foram novamente lavados em PBS e em seguida em solução de bloqueio e incubados com anticorpo secundário biotilinado (VECTASTAIN $^{\circledR}$ Elite $_{\circledast}$ ABC System- Vector Laboratórios; CA, USA), por uma hora à temperatura ambiente. A atividade da peroxidase foi revelada usando o cromógeno 3,3 Diaminobenzidina (DAB, Sigma Química Co.; MO, EUA). As lâminas foram lavadas abundantemente em água corrente e contra-coradas com hematoxilina de Harris (Merck; Darmsadt, Alemanha). Depois, foram lavadas mais uma vez em água corrente, desidratadas e montadas com resina Permount (Fisher Científica; NJ, USA) para visualização ao microscópio óptico. As expressões das moléculas de adesão bem como 
da enzima foram quantificadas utilizando o programa ImageJ (Image Processing and Analysis in Java, www.imagej.nih.gov).

\subsection{Coloração hematoxilina e eosina (HE)}

Os pulmões foram envolvidos em solução de paraformoldeído 4\% /PBS por vinte e quatro horas. Após este período a solução foi trocada por álcool etílico (Merck, Darmstadt, Alemanha) $70 \%$ e armazenada a $4{ }^{\circ} \mathrm{C}$ até o uso. Na preparação das lâminas, os tecidos foram lavados em gradientes de concentração de álcool etílico (96\% e 100\%) por três vezes em cada e por um período de trinta minutos. A lavagem continuou em solução de xilol (Merck, Darmstadt, Alemanha) (50\%, 70\% e 100\%) por quinze minutos cada. Os tecidos foram então inseridos em parafina líquida, esfriados, cortados em Micrótomo em secções de $5 \mu \mathrm{m}$ e fixados em lâminas.

Inicialmente, a desparafinização da lâmina silanizada (Knittel Glaser, Bielefeld, Alemanha) contendo o tecido foi feita em estufa (60 ${ }^{\circ} \mathrm{C}, 15$ minutos) e em solução de xilol $100 \%$ por dez minutos. A hidratação da mesma se deu a partir de uma bateria de soluções alcoólicas (Merck, Darmstadt, Alemanha) em concentrações graduais decrescentes $(100 \%, 95 \%)$ e água. Depois a lâmina foi corada com hematoxilina de Carazzi (Merck, Darmstadt, Alemanha) por 5 minutos e lavada com água corrente. Corada novamente com eosina (Merck, Darmstadt, Alemanha) por sete minutos e lavada em água corrente. Finalmente, desidratada em soluções alcoólicas graduais crescentes (70\%, 95\% e 100\%). Posteriormente, a lâmina recebeu uma lamínula a qual foi colada com Entellan (Merck, Darmstadt, Alemanha).

\subsection{Extração de RNA}

O RNA total foi extraído dos pulmões, para análise dos RNAm para as enzimas da AA-NAT, ASMT, SOD, CAT e GPx utilizando-se o reagente Trizol, conforme instruções do fabricante. Resumidamente, os pulmões foram homogeneizadas em Trizol e o RNA foi isolado pela adição de clorofórmio, seguida de centrifugação (12000 x g; 15 $\min ; 4^{\circ} \mathrm{C}$ ). O RNA foi precipitado com isopropranol, submetido à centrifugação (12000 $\mathrm{x}$ g; $10 \mathrm{~min} ; 4^{\circ} \mathrm{C}$ ) e, após remoção do sobrenadante, foi lavado duas vezes com etanol 
$75 \%$ seguido de centrifugação ( $\left.7500 \times \mathrm{g} ; 5 \mathrm{~min} ; 4^{\circ} \mathrm{C}\right)$. O etanol foi removido e o RNA foi solubilizado em água de injeção estéril (Beker, Brasil). A determinação da quantidade de RNA foi feita no espectrofotômetro Nanodrop ND-1000, e o extrato do RNA obtido foi tratado com DNase I de acordo com as instruções do fabricante, para remoção de possível contaminação com DNA.

\subsection{Análise da expressão gênica por RT-PCR em tempo real}

A técnica de reação em cadeia da polimerase por transcriptase reversa (RT-PCR) em tempo real foi realizada para análise da expressão gênica das enzimas AA-NAT, ASMT, SOD, CAT e GPx bem como do gene da enzima gliceraldeído-3-fosfato desidrogenase (GAPDH), cuja expressão foi utilizada para normalização dos dados. Após a extração, 0,5 a $1 \mu \mathrm{g}$ de RNA total de cada amostra foi utilizado para a síntese de cDNA (DNA complementar) em reação catalisada pela enzima transcriptase reversa Superscript III (200U, Invitrogen), em tampão específico contendo primers randômicos (50 ng) e dNTPs (10 mM). A reação foi realizada em termociclador (Eppendorf, Hamburog, Alemanha), nas condições indicadas pelo fabricante da enzima. Posteriormente, o PCR em tempo real foi realizado incubando-se $1 \mu \mathrm{L}$ de cDNA com primers específicos para cada gene de interesse (tabela 1), nas concentrações de 200 nM para os primers senso e anti-senso de AA-NAT, CAT e GADPH e de $400 \mathrm{nM}$ para ASMT, SOD e GPX, em solução do reagente SYBR Green, utilizando-se o termociclador iCycler (BioRad). Os resultados foram calculados pelo método $\Delta \Delta \mathrm{Ct}$ (delta-delta cycle threshold), no qual Ct refere-se ao número de ciclos necessários para a detecção do amplicon; o primeiro delta é a diferença entre o Ct do gene de interesse e o Ct do gene normalizador (no caso, o Gapdh), e o segundo delta refere-se à diferença entre os deltaCt da amostra experimental e da média das amostras controle. Assim, através da fórmula $2^{-{ }_{\Lambda \Lambda} \mathrm{Ct}}$, os valores obtidos indicam a magnitude da alteração na expressão gênica do grupo tratado com relação ao grupo controle (fold-change). Ao final de todas as reações foi realizada a curva de dissociação (melting curve) para verificar a especificidade da reação. 
Tabela 1 - Sequência dos primers utilizados para análise da expressão gênica das enzimas AA-NAT, ASMT, SOD, CAT e GPX.

\begin{tabular}{|c|c|c|}
\hline Gene & Sentido do primer & Sequência \\
\hline \multirow[t]{2}{*}{ AA-NAT } & Senso & 5' - AGCGCGAAGCCTTTATCTCA - 3' \\
\hline & Antisenso & 5' - AAGTGCCGGATCTCATCCAA - 3' \\
\hline \multirow[t]{2}{*}{ ASMT } & Senso & 5' - AGCGCCTGCTGTTCATGAG - 3' \\
\hline & Antisenso & 5' - GGAAGCGTGAGAGGTCAAAGG - 3' \\
\hline \multirow[t]{2}{*}{ SOD } & Senso & 5' - AAGCGGTGAACCAGTTGTGG- 3' \\
\hline & Antisenso & 5’ - AAAATGAGGTCCTGCAGTTGGT- 3’ \\
\hline \multirow[t]{2}{*}{ CAT } & Senso & 5' -GCAGATACCTGTGAACTGTC - 3' \\
\hline & Antisenso & $5^{\prime}$ - ATAGAATGTCCGCACCTGAG- 3' \\
\hline \multirow[t]{2}{*}{ GPx } & Senso & 5' - GCAATCAGTTCGGACATCAGG - 3' \\
\hline & Antisenso & $5^{\prime}$ - CTCACCATTCACCTCGCACT - 3' \\
\hline \multirow[t]{2}{*}{ GADPH } & Senso & $5^{\prime}$ - TTCTTGTGCAGTGCCAGCC - $3^{\prime}$ \\
\hline & Antisenso & $5^{\prime}$ - GTAACCAGGCGTCCGATACG - 3' \\
\hline
\end{tabular}

\subsection{TBARS}

A concentração de substâncias reativas ao ácido tiobarbitúrico (TBARS) foi utilizado na quantificação do estresse oxidativo nos pulmões por colorimetria. Foram adicionados $250 \mu \mathrm{L}$ de solução de ácido tiocloroacético (TCA 10\%) aos $500 \mu \mathrm{L}$ do sobrenadante do tecido pulmonar ( descrito no item 3.4) homogeneizado e centrifugado (18.000 x g, $15 \mathrm{~min}, 15^{\circ} \mathrm{C}$ ). Posteriormente, $500 \mu \mathrm{l}$ do sobrenadante foram transferidos para um criotubo e adcionados $500 \mu \mathrm{l}$ de ácido tiobarbitúrico (TBA 1\% em 0,05 N de $\mathrm{NaOH})$, mantidos em banho maria $\left(100^{\circ} \mathrm{C}\right)$ por 10 minutos, sendo após resfriados em banho de gelo $\left(0^{\circ} \mathrm{C}\right)$. O TBARS foi então quantificado usando um especrofotômetro (UV-vis Spectrophotometer Ultrospec 3300 Pro; Biochrom Ltd., Cambridge, UK) a um comprimento de onda de $532 \mathrm{~nm}$. Os resultados foram comparados com uma curva padrão de solução de malondialdeído (MDA), produto resultante da peroxidação lipídica e que reage com o ácido tiobarbitúrico formando uma solução de coloração rosa. $A$ peroxidação lipídica foi representada por pM de MDA / mg de tecido pulmonar (Nichi et al., 2006).Todos os reagentes químicos usados aqui foram da Sigma-Aldrich (St. Louis, MO, USA). 


\subsection{Atividade enzimática}

As atividades da SOD, CAT e GPx foram obtidas por espectrofotometria (especrofotômetro UV-vis Spectrophotometer Ultrospec 3300 Pro; Biochrom Ltd., Cambridge, UK) a partir do ensaio de cinética enzimática também descrito anteriormente por Nichi et al. (2006).

\subsubsection{Superóxido desmutase (SOD; E.C.1.15.1.1)}

Este ensaio consistiu em misturar $10 \mu \mathrm{l}$ do sobrenadante do tecido pulmonar (descrito no item 3.4) com $835 \mu \mathrm{l}$ de solução contendo o citocromo $\mathrm{C}(1 \mathrm{mM})$, xantina (50 $\mathrm{mM}$ ) e $155 \mu \mathrm{l}$ de xantina oxidase diluída em tampão de fosfato de sódio/EDTA (50 mM e $100 \mathrm{mM}$, respectivamente, $\mathrm{pH}$ 7,8). A concentração e xantina oxidase foi calculada para gerar uma concentração ótima de superóxido com a consequente redução do citocromo C a uma taxa de 0,025 unidades de absorbância por minuto a um comprimento de onda de $550 \mathrm{~nm}$. A base para este cálculo é que 1 unidade da atividade da SOD corresponde a $50 \%$ deste valor. Portanto, a atividade da SOD na amostra diminui a taxa de redução do citocromo $\mathrm{C}$ quando comparada com o branco, verificando-se portanto, a competição entre a SOD e o citocromo $C$. Todos os reagentes químicos foram da Sigma-Aldrich (St. Louis, MO, USA).

\subsubsection{Catalase (CAT; E.C.1.11.1.6)}

Adicionou-se a $20 \mu \mathrm{l}$ do sobrenadante do tecido pulmonar (descrito no item 3.4), $110 \mu \mathrm{l}$ de solução tampão Tris-HCl /EDTA pH 8,0 (1 M e 5 mM, respectivamente) além de $450 \mu \mathrm{l}$ de $\mathrm{H}_{2} \mathrm{O}_{2}(9 \mathrm{mM})$. A reação aconteceu a $30^{\circ} \mathrm{C}$ por 8 minutos, sendo que a atividade enzimática foi medida usando um espctrofotômetro (UV-vis Spectrophotometer Ultrospec 3300 Pro; Biochrom Ltd., Cambridge, UK) a um comprimento de onda de 230 nm. A absorbância foi medida a cada 5 segundos e a curva de consumação do $\mathrm{H}_{2} \mathrm{O}_{2}$ foi comparada com o branco. Todos os reagentes químicos foram da Sigma-Aldrich (St. Louis, MO, USA). 
3.16.3 Glutationa peroxidase (GPx; E.C.1.11.1.9)

Em $50 \mu$ do sobrenadante do tecido pulmonar (descrito no item 3.4), adicionou-se $500 \mu \mathrm{l}$ de NADPH $(0,12 \mathrm{mM}), 50 \mu \mathrm{l}$ de GSH $(1 \mathrm{mM}), 10 \mu \mathrm{l}$ de GSSGr $(0,25 \mathrm{U} / \mathrm{mL}), 10 \mu \mathrm{l}$ de azida sódica $(0,25 \mathrm{mM})$ e com 330 ul de tampão fosfato de sódio/EDTA (143 mM e 6,3 mM, pH 7,5). A reação foi iniciada pela adição de $50 \mu \mathrm{l}$ de terc-butilhidroperóxido (tBHP 1,2 mM). O consumo do NADPH foi detectado usando um espctrofotômetro (UVvis Spectrophotometer Ultrospec 3300 Pro; Biochrom Ltd., Cambridge, UK) a um comprimento de onda de $340 \mathrm{~nm}$ por 10 minutos a $37^{\circ} \mathrm{C}$. A absorbância foi medida a cada 5 segundos. Todos os reagentes químicos foram da Sigma-Aldrich (St. Louis, MO, USA).

\subsection{MIA (Multiplex immunoassays)}

A detecção das citocinas foi realizada através do ensaio MIA (Multiplex immunoassays) utilizando-se kits comerciais (MILLIPLEX MAP Merck Millipore Rat Cytokine/Chemokine Magnetic Bead Panel, RECYTMAG-65), de acordo com as instruções do fabricante.

\subsection{Análise estatística dos resultados}

Os dados estão apresentados como média \pm erro padrão da média (e.p.m.) obtidos a partir de experimentos independentes. A comparação entre médias foi feita através do teste $t$ de student e de três ou mais médias através de análise de variância seguida do pós-teste de Newman-Keuls . A probabilidade de $5 \%$ foi considerada como diferença significativa entre os grupos. Toda a análise estatística foi feita por meio do software GraphPad Prism® versão 6.00 (Trial) (GraphPad Software@). 
Resultados 


\section{RESULTADOS}

\subsection{Caracterização da resposta inflamatória após exposição aguda in vivo ao material particulado fino $\left(\mathrm{MP}_{2,5}\right)$}

\subsubsection{Geração do estresse oxidativo pelo material particulado fino $\left(\mathrm{MP}_{2,5}\right)$}

O material particulado fino apresenta características físicas, químicas e biológicas e a sua composição é um fator determinante na sua capacidade de gerar respostas celulares. Com base numa revisão de trabalhos in vitro, um mecanismo hipotético para os malefícios gerado pelo material particualado fino é a sua capacidade de gerar um estresse oxidativo, por esta razão, verificamos se a exposição aguda in vivo ao poluente seria capaz de gerar tal resposta.

O estresse oxidativo no tecido pulmonar foi estimado a partir da peroxidação lipídica, quantificando-se a formação de um lípide oxidado, o malondialdeído (MDA). O material particulado fino provoca um aumento progressivo do estresse oxidativo pulmonar. Na primeira hora de exposição ao material particulado não foi observada diferença significativa em relação ao grupo exposto ao ar filtrado, já em duas horas a peroxidação lipídica aumentou em 83,5\% e em seis horas, em 278,6\% (figura 9).

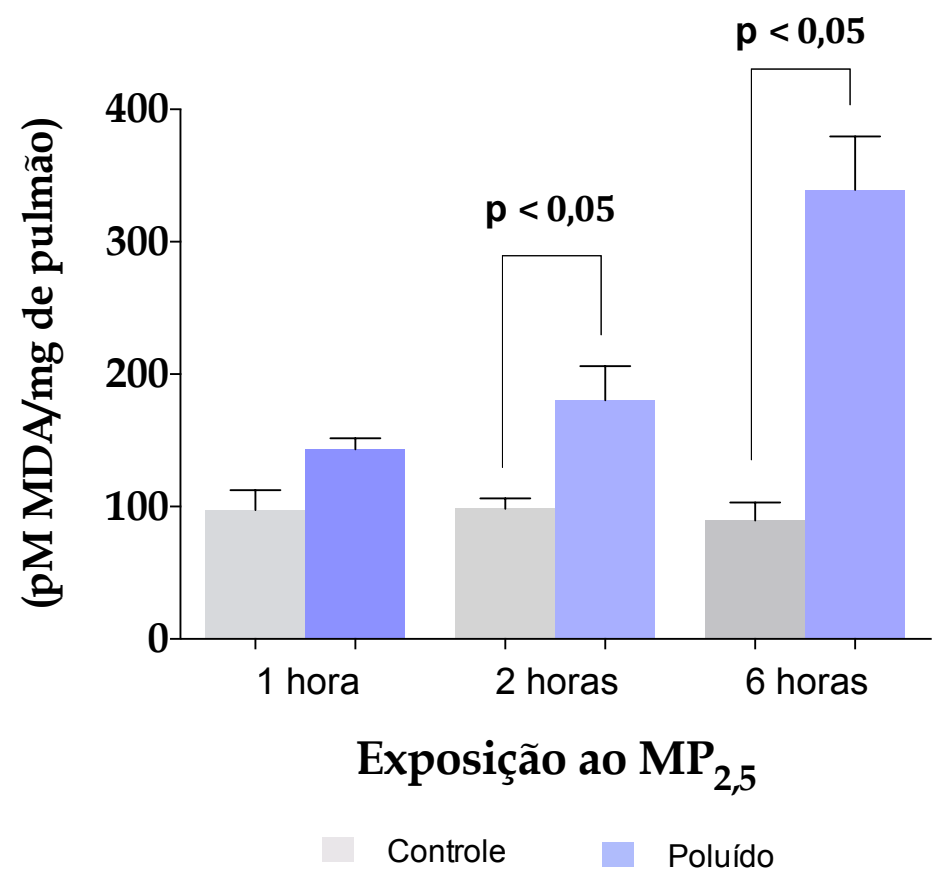

Figura 9 - Geração do estresse oxidativo pelo material particulado fino $\left(\mathrm{MP}_{2,5}\right)$ a partir da quantificação da peroxidação lipídica. A peroxidação lipídica pulmonar dos grupos foram determinados pelo ensaio do TBARS (pM MDA/mg de tecido pulmonar). Os dados expressos como a 
média \pm SEM, $n=5-12$ animais por grupo de três experimentos diferentes. Significativamente diferente $(p<0,05)$ vs grupo controle.

\subsubsection{Inflamação pulmonar pelo material particulado fino $\left(\mathrm{MP}_{2,5}\right)$}

Nesta etapa avaliamos histologicamente a capacidade da inalação ao material particulado fino em instalar no pulmão um quadro inflamatório. Os parênquimas pulmonares dos animais poluídos apresentam visivelmente características inflamatórias como a redução do lúmen do bronquíolo, espessamento da musculatura lisa que o envolve, bem como a migração de células polimorfonucleares (PMN) e mononucelares $(\mathrm{MN})$ do vaso para a vias aéreas (figura 10).
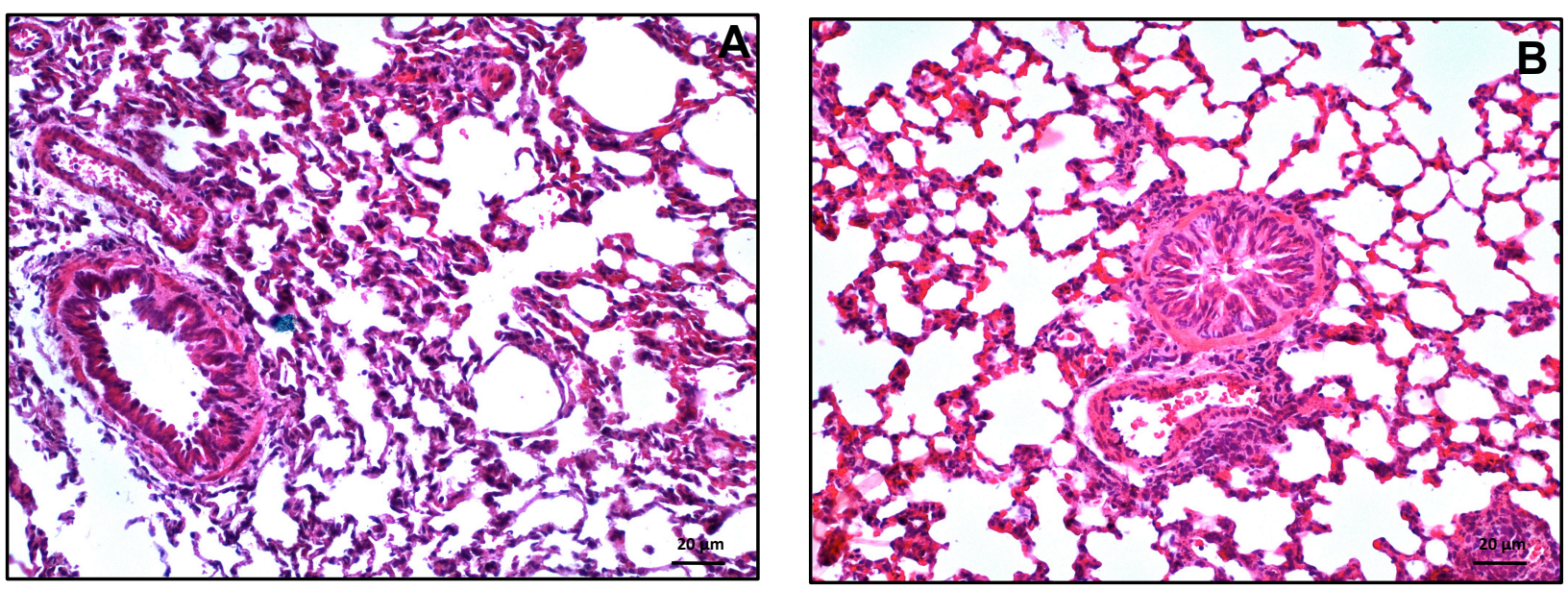

Figura 10 - Geração do processo inflamatório pelo material particulado fino $\left(\mathrm{MP}_{2,5}\right)$ no parênquima pulmonar, coloração por HE. A - Parênquimas pulmonares de animais controles (aumento $20 \mathrm{x}$ ). B - Parênquimas pulmonares de animais expostos ao material particulado fino $\left(\mathrm{MP}_{2,5}\right)$ (aumento $20 \mathrm{x}$ ). $\_20 \mu \mathrm{m}$

\subsubsection{Ativação do fator de transcrição NF-kB pelo material particulado fino $\left(\mathrm{MP}_{2,5}\right)$ no pulmão}

O fator de transcrição NF-kB é responsável pela transcrição gênica de elementos envolvidos no processo inflamatório. Dessa forma, avaliamos a capacidade do material particulado fino, exposto agudamente, em ativar a via do fator de transcrição NF-kB em pulmões. Através dos ensaios de gel-shift detectamos que o material particulado fino ativa a via do $\mathrm{NF}-\mathrm{kB}$, induzindo a translocação nuclear de suas subunidades em uma hora de exposição. A medida que o tempo de 
exposição ao material particulado fino aumenta, estes tempos apresentam o mesmo efeito máximo quanto ao conteúdo nuclear de NF-кB (figura 11), sugerindo que a exposição ao material particulado apresenta uma rápida e intermitente atividade deste fator de transcrição. Em todos os tempos foi verificada a formação de dois complexos DNA-proteína (C1 e C2).

A

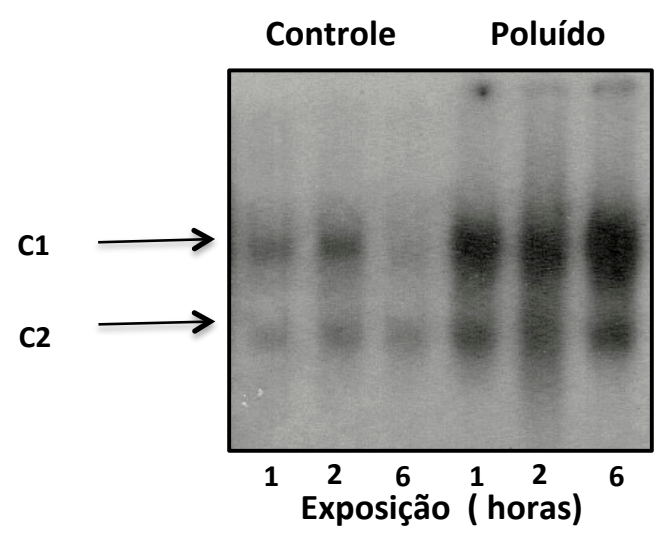

B
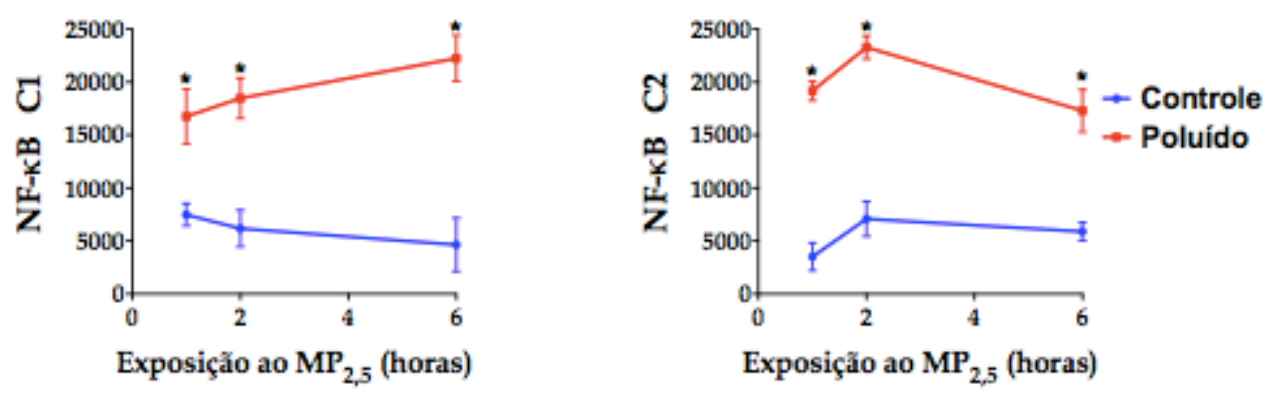

Figura 11 - Efeito do material particulado fino $\left(\mathrm{MP}_{2,5}\right)$ sobre a translocação nuclear do fator NFKB. A - Para cada tempo de exposição ao material particulado está representado à esquerda a autorradiografia obtida em extratos nucleares por EMSA, utilizando oligonucleotídeo para NF-KB marcado com radioisótopo ${ }^{32} \mathrm{P}$, evidenciando a formação de dois complexos proteína-DNA (NF-KB C1 e C2). B - Quantificação densitométrica dos complexos C1 e C2 das autoradiografias obtidas no ensaio de EMSA. Os dados estão representados pela média \pm e.m.p., $\mathrm{N}=2$ géis, 5 pulmões para cada grupo e tempo de exposição por gel. ${ }^{*}$ Significativamente diferente $p<0,05$ vs grupo controle.

A caracterização das subunidades envolvidas na ativação de NF-кB induzida pelo material particulado fino foi realizada através da técnica de super-shift, na qual anticorpos específicos de cada subunidade foram incubados com os extratos proteicos nucleares. Os anticorpos para p50, RelA são eficazes em retardar a migração dos complexos de NF-kB-DNA, diminuindo a intensidade das bandas observadas na ausência de anticorpos (figura 12), comprovando, portanto que o 
material particlado fino ativa a formação de dímeros compostos por p50 e RelA. Este perfil de resposta indica que os complexos contém as proteínas aos quais os anticorpos se ligaram. Esse resultado foi observado em ambos os grupos, controle e exposto ao material particulado fino, sendo que no grupo tratado os níveis de NF-кB nuclear estão nitidamente aumentados.

Devido à posição das bandas que sofreram deslocamento em relação às amostras sem anticorpo (figura 12), é possível concluir que a primeira banda observada no gel compreende na verdade dois complexos muito próximos entre si (C1a e C1b), correspondentes aos dímeros p50-p50 e p50-RelA, respectivamente. Isso torna-se evidente ao utilizarmos simultaneamente os anticorpos contra p50 e RelA, o que acarreta em remoção total dos complexos $\mathrm{C} 1 \mathrm{a}$ e $\mathrm{C} 1 \mathrm{~b}$. O segundo complexo observado (C2) foi considerado não-específico (N.E.) devido ao fato de não ser alterado na presença de nenhum anticorpo.

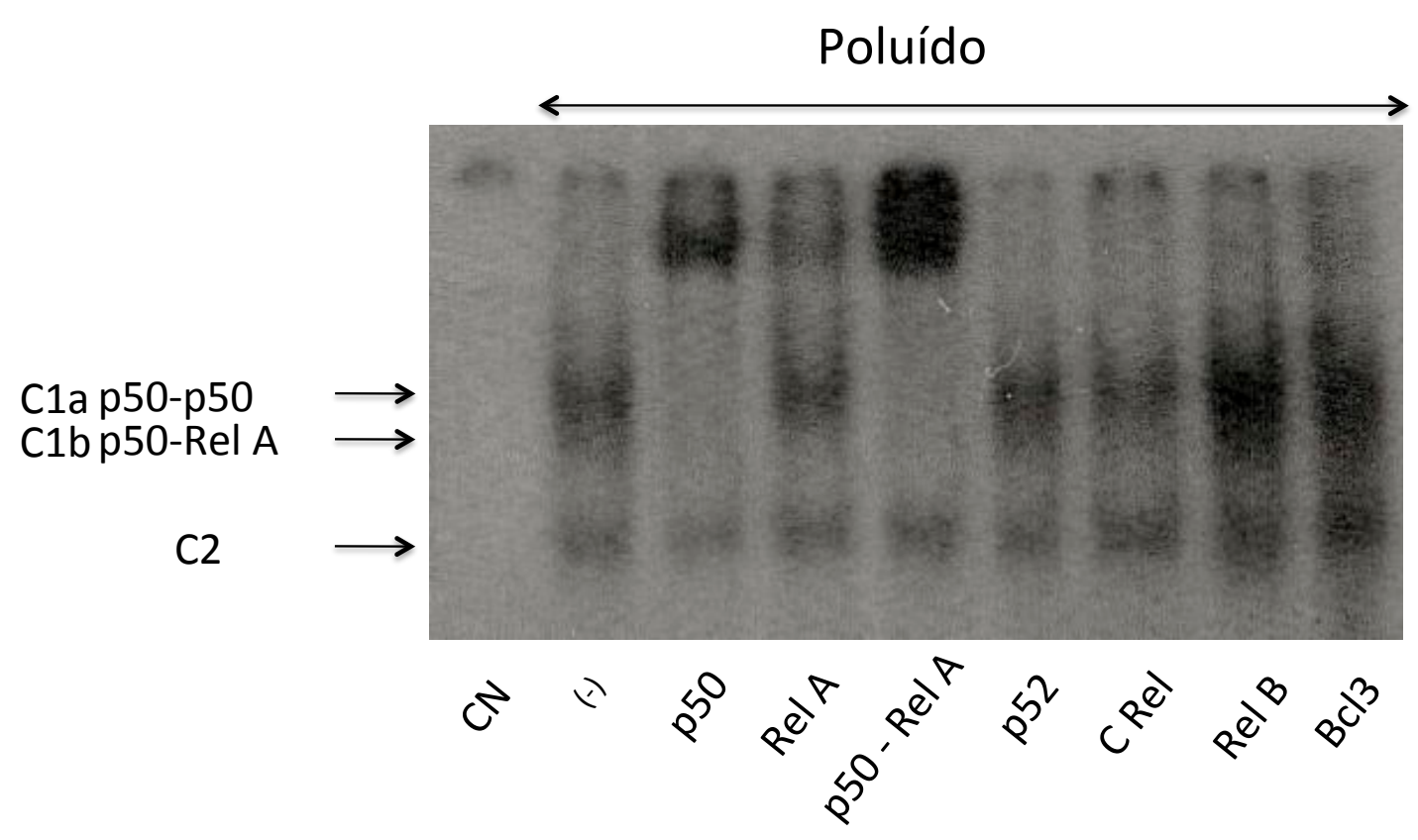

Figura 12. Efeito do material particulado fino $\left(\mathrm{MP}_{2,5}\right)$ sobre a translocação nuclear de subunidades do fator NF-кB. Autoradiografia representativa do ensaio de supershift para cada subunidade (p50, RelA, p52, cRel, RelB e Bcl 3) em pumões de animais poluídos. (-) indica ausência de anticorpo; $\mathrm{CN}=$ controle negativo (ausência de extrato proteico); $\mathrm{C} 1 \mathrm{a}, \mathrm{C} 1 \mathrm{~b}$ e $\mathrm{C} 2$ = complexos observados. Cada ponto foi obtido a partir de um homogenato de 6 pulmões. 
4.1.4 Produção de proteínas controladas pelo NF-אB no pulmão após exposição ao $\mathrm{MP}_{2,5}$

A ativação do NF-кB por moléculas pró-inflamatórias clássicas, como o LPS e a citocina TNF- $\alpha$, induzem a transcrição de diversos genes, particularmente aqueles envolvidos com a resposta imune inata e inflamatória. Vários mediadores da resposta inflamatória, como citocinas, moléculas de adesão, a enzima iNOS, a ciclooxigenase 2 (COX2), e a própria proteína inibitória IkB produzida como um

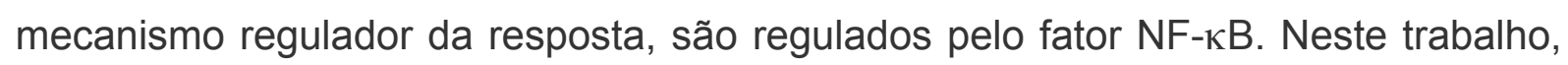
escolhemos avaliar a expressão das moléculas de adesão e da iNOS em células

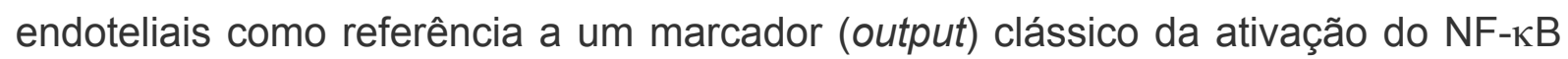
na resposta inflamatória. Atestamos, portanto que os pulmões apresentam expressões basais e constitutivas de moléculas de adesão (PECAM-1 e ICAM-1) e da enzima sintase de óxido nítrico induzida (iNOS) em veias pulmonares e que a exposição ao material particulado fino induz a um aumento significativo de $71,09 \%$, $181,46 \%$ e $68,91 \%$ respectivamente, na expressão destes marcadores quando comparados com seus controles (figura 13).

A

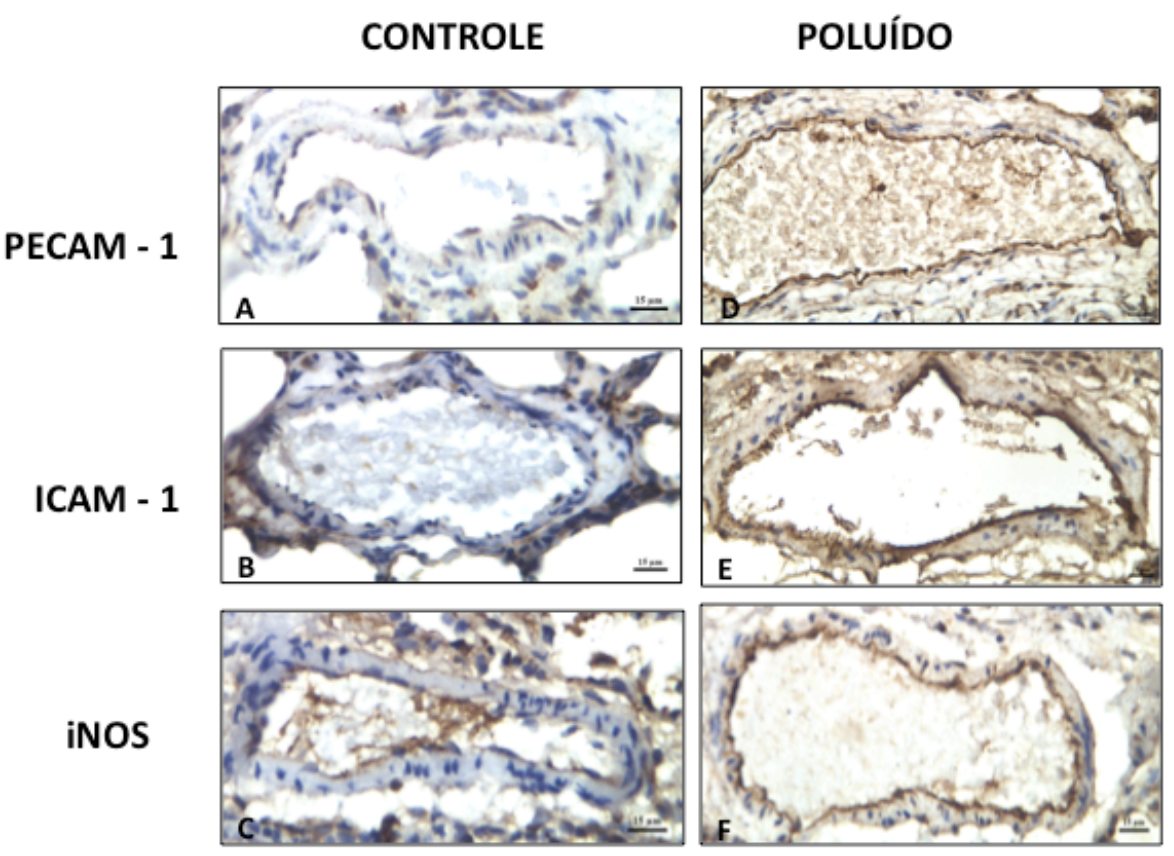




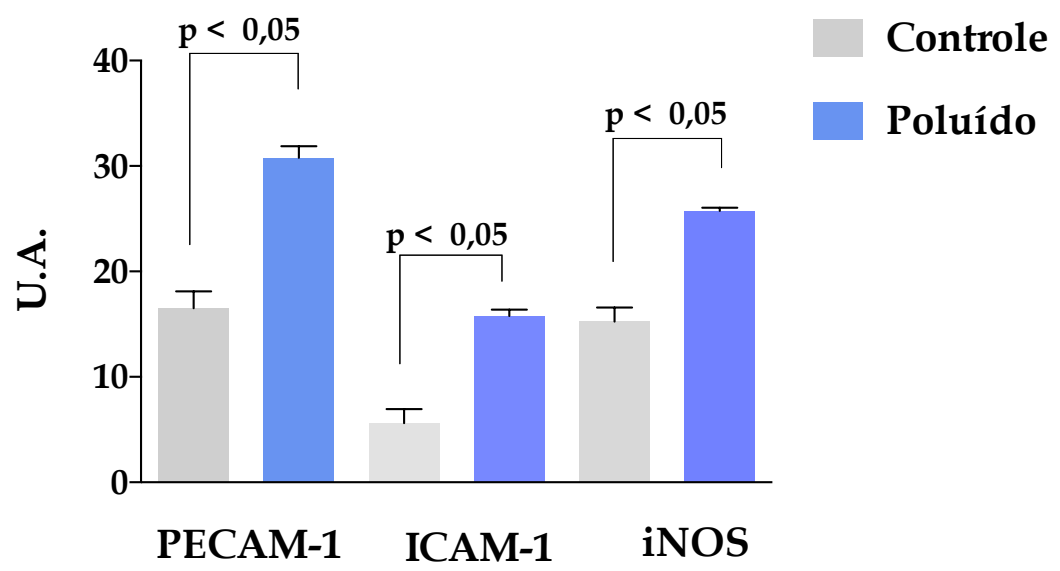

Figura 13 - Efeito do material particulado fino $\left(\mathrm{MP}_{2,5}\right)$ sobre a expressão de moléculas de adesão PECAM-1, ICAM-1 e da enzima iNOS em veias pulmonares. A - As figuras A, B e C representam imagens do ensaio imunohistoquímico do grupo controle para PECAM-1, ICAM-1 e iNOS, respectivamente. As figuras $D, E$ e $F$ representam imagens do ensaio imunohistoquímico do grupo poluído para PECAM-1, ICAM-1 e iNOS, respectivamente. Barra de escala - $20 \mu \mathrm{m}$. B Quantificação das expressões das moléculas de adesão PECAM-1, ICAM-1 e da enzima iNOS em veias pulmonares através do programa Image $\mathrm{J}$ em grupos controle e poluído. Os dados estão representados pela média \pm e.m.p., $n=5$ pulmões para cada grupo experimental .Significativamente diferente $p<0,05$ vs grupo controle.

\subsubsection{Material particulado fino $\left(\mathrm{MP}_{2,5}\right)$ e os níveis plasmáticos de citocinas}

Comprovamos até o momento que a exposição aguda ao material particulado fino gera uma resposta inflamatória pulmonar local. Para atestar se esta mesma exposição geraria uma resposta inflamatória sistêmica, analisamos a presença de diferentes citocinas plasmáticas através do ensaio MIA (Multiplex Immunoassay) (figura 14).

As concentrações plasmáticas do TNF $-\alpha$ e da IL-6 apresentaram um aumento significativo em meia, segunda e sexta hora de exposição quando comparadas com seus respectivos controles. A citocina IL-12 também mostrou um aumento a medida que o tempo de exposição ao material particulado fino acresceu, porém com diferenças relevantes apenas a partir da segunda e sexta hora. As concentrações plasmáticas das citocinas IFN- $\gamma$, IL -1a e IL-4 apresentaram um aumento considerável e transitório, ou seja, em trinta minutos de exposição as diferenças entre os grupos tratados e controles foram expressivas e que deixaram de ser observadas quando os animais foram mantidos por duas e seis horas. As IL$1 \beta$, IL-2 e a MCP-1 não foram alterados pela poluição do ar. Vale ressaltar que em 
nosso modelo não observamos diferenças nas concentrações de citocinas entre os grupos naives e controles.
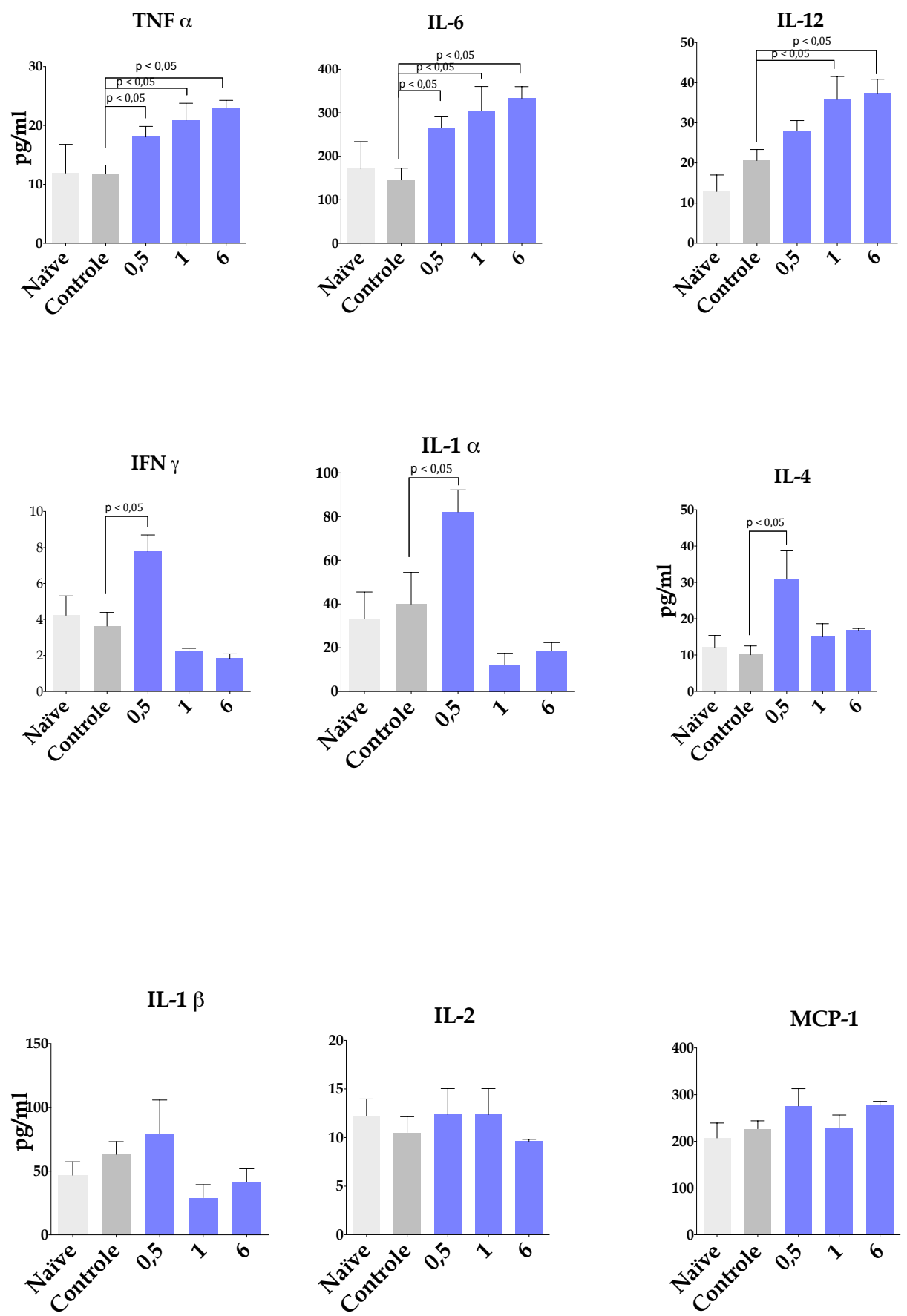

\section{Tempo (horas)}

\section{Exposição ao $\mathrm{MP}_{2,5}$ \\ Controle

$$
\text { Poluído }
$$

Figura 14 - Efeito do material particulado fino $\left(\mathrm{MP}_{2,5}\right)$ sobre os níveis de citocinas inflamatórias. Concentração plasmática de citocinas em ratos expostos por $0,5,1 \mathrm{~h}$ e $6 \mathrm{~h}$ (barras azuis) ou não à poluição, grupo naive (barra branca) e controle (barra cinza). Níveis de TNF- $\alpha$, IL-1 $\beta$, IL-1 $\alpha$, INF- $\gamma$, IL6, IL-2, IL-4, MCP-1 e IL-12 (pg/mL). Os dados estão expressos como média \pm e.p.m; $n=4-8$ animais. Significativamente diferente $p<0.05$ vs. controle. 


\subsection{Efeito do material particulado fino $\left(\mathrm{MP}_{2,5}\right)$ sobre o conteúdo plasmático e pulmonar de melatonina após exposição aguda in vivo}

\subsubsection{Efeito do material particulado fino $\left(\mathrm{MP}_{2,5}\right)$ sobre a produção de corticosterona e} melatonina após exposição aguda in vivo

Como as câmaras de exposição ao material particulado fino, (animais poluídos) e ao ar filtrado (animais controle) poderiam gerar condições de estresse, foram dosadas as concentrações plasmáticas de corticosterona e melatonina destes animais bem como dos naives, uma vez que a partir de dados literários é sabido existir uma interação entre a glândula adrenal e a glândula pineal (NERISERNERI; BARTOLI, 1957; VAUGHAN; REITER, 1971).

Foi verificado que tanto os animais expostos ao material particulado fino quanto os exposto ao ar filtrado apresentam um aumento transiente das concentrações plasmáticas de corticosterona e melatonina. O pico de corticosterona ocorre aos 15 minutos de exposição e o de melatonina aos 30 minutos de exposição. Em seguida, os valores plasmáticos de melatonina dos animais controles retornam aos níveis basais, que são semelhantes aos observados nos animais mantidos nas estantes convencionais. Já os valores plasmáticos de melatonina apresentaram uma importante diferença entre os animais expostos ao ar filtrado ou ar poluído. No primeiro caso, acompanharam os valores plasmáticos.

Conforme os resultados descritos na figura 15, observamos que aos 30 minutos dentro da câmara, tantos os animais expostos ao ar filtrado $(337,20 \pm 55,63$ $\mathrm{ng} / \mathrm{mL}$ ) quanto ao poluído (611,80 $\pm 51,78 \mathrm{ng} / \mathrm{mL})$ apresentaram um aumento significativo na concentração da corticosterona quando comparados ao naive ( $108,70 \pm 63,35 \mathrm{ng} / \mathrm{mL}$ - animais que permaneceram fora das câmaras de exposição), além de apresentarem uma diferença significativa entre eles neste mesmo tempo, como se o material particulado fino estivesse potenciando em $80 \%$ a concentração da corticosterona circulante, o hormônio do estresse. Nos demais tempos não há diferenças entre os grupos.

Quando avaliamos os resultados na concentração plasmática de melatonina, observamos que em uma hora de exposição há um aumento na concentração do grupo controle $(153,80 \pm 19,74 \mathrm{pg} / \mathrm{mL})$ e poluído $(173,10 \pm 13,34 \mathrm{pg} / \mathrm{mL})$ em 42,0\% e $50,1 \%$, respectivamente, quando comparados com eles mesmos no tempo de meia hora e ao grupo naive $(68,1 \%$ e $89,1 \%$, respectivamente). Em duas horas de 
processo a concentração plasmática dos dois grupos caem $(92,71 \pm 5,27 \mathrm{pg} / \mathrm{mL}$ e $106,80 \pm 5,67 \mathrm{pg} / \mathrm{mL}$ ), apresentando ainda diferenças entre si. Na quarta e sexta hora de exposição, a concentração plasmática de melatonina do grupo poluído $(70,70 \pm 3,73 \mathrm{pg} / \mathrm{mL})$ apresenta uma redução na ordem de 40,0\% quando comparados aos respectivos controles, enquanto que o grupo controle $(106,50 \pm$ $6,45 \mathrm{pg} / \mathrm{mL})$ atinge os mesmos níveis do naive $(105,9 \pm 6,99 \mathrm{pg} / \mathrm{mL})$.

Quando comparamos os gráficos das concentrações plasmáticas de corticosterona e melatonina, detectamos que aos 30 minutos o acréscimo nos níveis de corticosterona nos grupos controle e poluído, modula o aumento da melatonina que ocorre aos trinta minutos depois, isto é no tempo de uma hora, corroborando desta forma com os dados que atestam uma correlação entre a glândula pineal e a adrenal. 

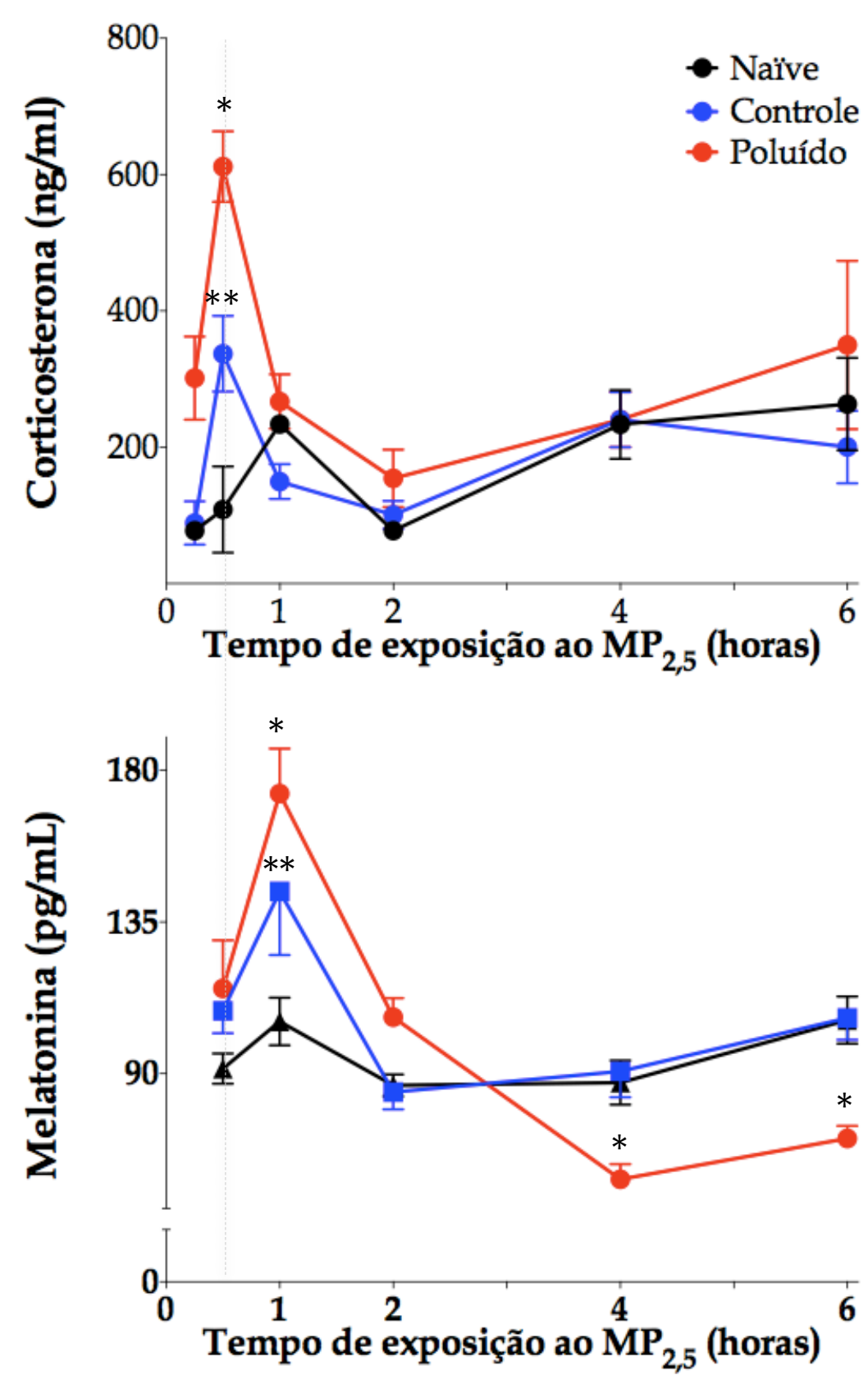

Figura 15 - Efeito do material particulado fino $\left(\mathrm{MP}_{2,5}\right)$ sobre a produção de corticosterona e melatonina. Concentração plasmática de corticosterona e melatonina em ratos expostos por $0,5,1 \mathrm{~h}$ e 6h (círculo vermelho) ou não à poluição ( círculo azul), grupo naive (círculo preto). Os dados estão expressos como média \pm e.p.m; $n=10-19$ animais. * Significativamente diferente $p<0.05$ poluído vs. naive. ${ }^{* *}$ Significativamente diferente $p<0.05$ controle vs. naive.

4.2.2 Efeito do material particulado fino $\left(\mathrm{MP}_{2,5}\right)$ sobre a produção de melatonina pela pineal e pelo pulmão após exposição aguda in vivo

A partir de dados da literatura sugerindo que o material particulado poderia gerar um resposta inflamatória e somado aos nossos resultados até então obtidos, tínhamos, uma série de indícios que poderiam atestar a hipótese de que em 
condições de ativação do sistema imunológico pelo material particulado fino, o mecanismo clássico de regulação da glândula pineal pela informação fótica ambiental deixaria de ser predominante e possibilitaria que a melatonina fosse produzida em concentrações e em locais condizentes com as necessidades do organismo.

Analisamos portanto, as concentrações plasmáticas e pulmonares de melatonina de animais, naive, controle e expostos ao material particulado. A concentração média de melatonina plasmática noturna encontrada nos animais do grupo controle foi de $(115,90 \pm 8,25 \mathrm{pg} / \mathrm{mL})$ enquanto que a diurna de $(38,56 \pm 3,57$ $\mathrm{pg} / \mathrm{mL}$ ). Observamos que não havia variação significativa nas concentrações de melatonina entre os animais controles e naives tanto no plasma quanto no pulmão quer seja dia quanto noite (figura 16).

As concentrações de melatonina plasmáticas noturnas dos animais expostos ao material particulado em três tempos distintos (1, 2 e 6 horas) apresentaram reduções significativas apenas nos animais expostos no maior tempo de exposição, passando de $(115,90 \pm 8,25 \mathrm{pg} / \mathrm{mL})$ para $(70,70 \pm 3,73 \mathrm{pg} / \mathrm{mL})$, mostrando uma diminuição na produção da melatonina pela pineal de forma transiente e dependente do tempo de exposição (figura $16 \mathrm{~B}$ ). Enquanto que nos pulmões destes mesmos animais ocorreu um acréscimo de 203,60 pg/g ( aumento de 55,0\%), ou seja, de ( $369,80 \pm 31,66 \mathrm{pg} / \mathrm{g})$, animais controle, para $(573,40 \pm 65,17 \mathrm{pg} / \mathrm{g})$, animais poluídos, indicando uma produção extra pineal de melatonina, evidenciando assim a ativação de eixo imune-pineal (figura $16 \mathrm{D}$ ). Estes dados sugerem fortemente uma alternância entre as fontes produtoras de melatonina.

A fim de comprovarmos a capacidade de produção de melatonina pelo pulmão, expusemos os animais a dois tempos distintos (1 e 6 horas) durante o dia (fase claro), onde é sabido haver uma concentração baixa de melatonina plasmática, uma vez que a produção desta indolamina pela pineal é inibida pela luz (SAKAi et al., 2001). Não foi detectada alteração da concentração de melatonina no pulmão após 1 hora de exposição quando comparado com o grupo controle, mas a exposição por 6 horas levou a uma aumento de 77,7\% (figura 16C). 


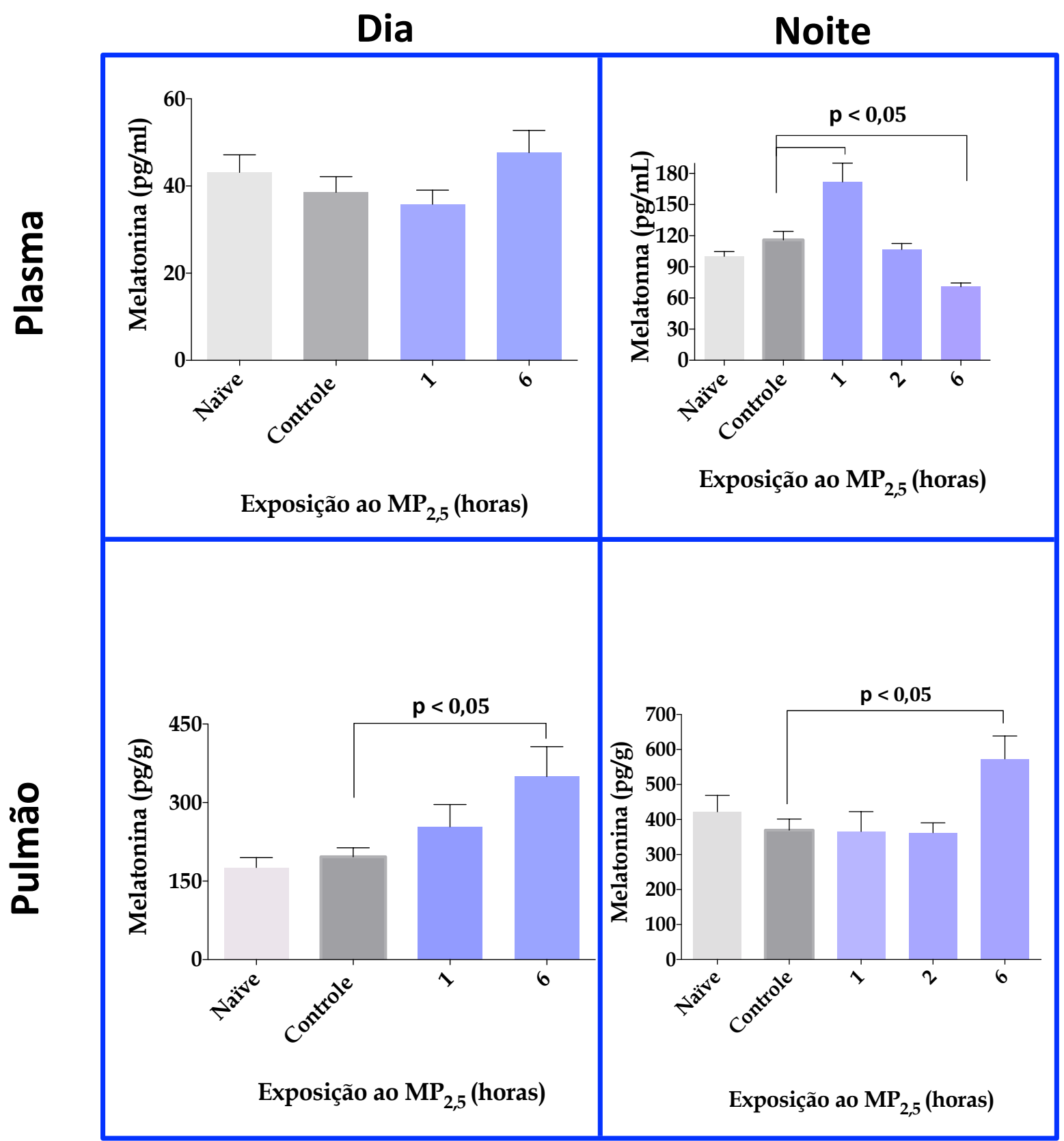

Figura 16 - $O$ Efeito do material particulado fino $\left(\mathrm{MP}_{2,5}\right)$ sobre a produção da melatonina pela glândula pineal e pulmonar. A - Efeito do material particulado sobre a concentração plasmática de melatonina diurna. B - Efeito do material particulado sobre a concentração plasmática de melatonina noturna. C - Efeito do material particulado sobre a concentração pulmonar diurna de melatonina. D Efeito do material particulado sobre a concentração pulmonar noturna de melatonina. Em todos os gráficos as concentrações plasmáticas e pulmonares de melatonina dos grupos foram determinadas por ELISA $(\mathrm{pg} / \mathrm{ml})$ e $(\mathrm{pg} / \mathrm{g})$. Os dados expressos como a média $\pm \mathrm{SEM}, \mathrm{n}=10-19$ animais por grupo de pelo menos dois experimentos diferentes. Significativamente diferente $p<0,05$ vs grupo controle.

As informações apresentadas pela figura 16 contribuem para a consolidação do conceito do eixo imune-pineal, onde para haver a instalação do quadro inflamatório em resposta a exposição ao material particulado, a concentração 
plasmática de melatonina noturna é reduzida e produzida localmente pelas células imunocompetentes.

Um dado que merece atenção são as quantidades de melatonina presentes nos pulmões dos animais naives e controles tanto dia quanto noite, sendo seu conteúdo (175,9 a 422,1 - pg/g) (figura 16 C e D) compatíveis com os valores encontrados em alguns órgãos do trato gastrointestinal (BUBENIK et al., 1997), sugerindo que a presença constante da melatonina neste órgão apresenta um caráter de proteção, uma vez o pulmão faz a interface do meio externo com o interno do organismo.

\subsection{Ativação do sistema antioxidante pulmonar após exposição aguda in vivo ao material particulado fino $\left(\mathbf{M P}_{2,5}\right)$}

Devido aos efeitos regulatórios da melatonina sobre o sistema de defesa desempenhado na segunda etapa da ativação do eixo imune-pineal, onde a indolamina é produzida localmente, partimos para verificar a expressão gênica no pulmão das enzimas chaves na biossíntese da melatonina, a arilalquilamina-Nacetiltransferase (AA-NAT) e a acetilserotonina metiltransferase (ASMT), de forma a se confirmar que se trata de uma produção pulmonar e não do acúmulo da melatonina proveniente do plasma. Avaliamos ainda a expressão gênica da superóxido dismutase (SOD), da catalase (CAT) e da glutationa peroxidase (GPx) sendo estas três últimas resultantes da capacidade desta indolamina em induzir a expressão de enzimas antioxidantes. (ANTOLIN et al.1996; BARLOW-WALDEN et al.,1995; LIU; NG, 2000). É significativo lembrar que uma das respostas celulares iniciais ao estresse oxidativo é a ativação das enzimas antioxidantes. Os níveis do RNA mensageiro das enzimas AA-NAT e ASMT duplicaram e triplicaram, respectivamente, em relação ao controle após a exposição de seis horas ao material particulado, indicando haver uma demanda na biossíntese de melatonina, concluindo desta forma que o material particulado modula apenas a transcrição gênica destas enzimas (figura 18). 

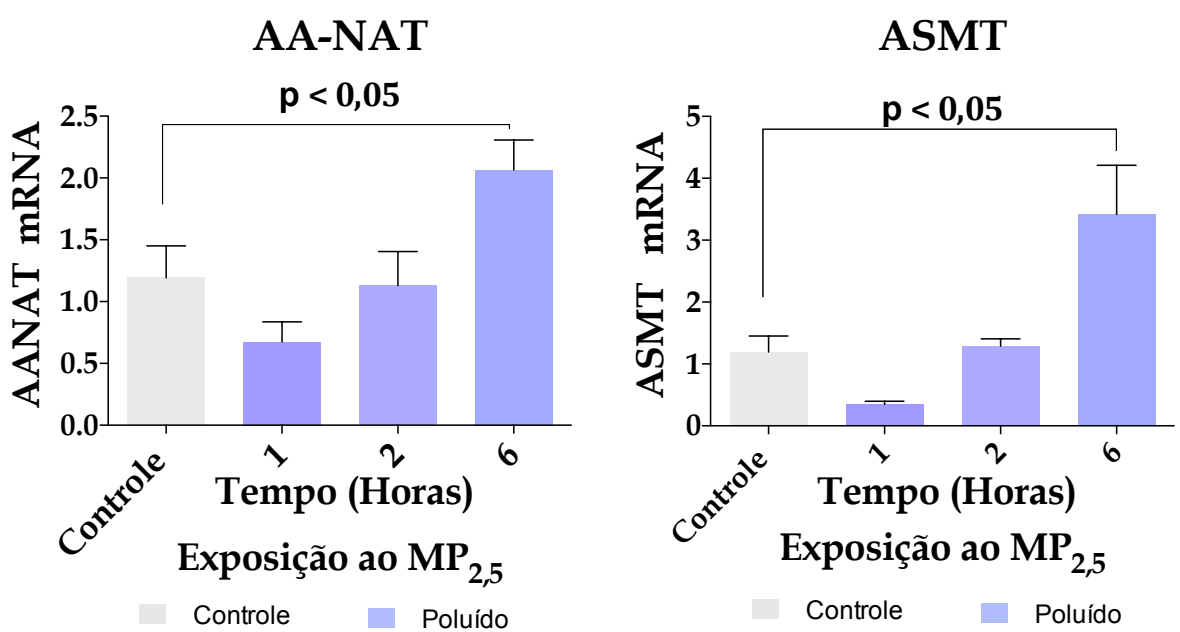

Figura 17 - Efeito da exposição ao material particulado fino (MP 2.5 ) na transcrição do RNAm das enzimas AA-NAT eASMT. As concentrações do RNAm da AA-NAT e ASMTnos pulmões de ratos expostos ao MP 2,5 e controle foram determinados por RT-PCR em tempo real. Os valores foram normalizados em relação aos pulmões dos ratos controle não expostos à poluição. Os dados estão expressos como a média \pm e.m.p., $n=6-7$ animais.Significativamente diferente $(p<0,05)$ vs grupo controle.

A modulação da transcrição gênica para as enzimas antioxidantes, SOD, CAT e GPx também é dependente da concentração do material particulado fino, apresentando diferença significativa apenas no de maior tempo, onde os seus valores duplicam em todas as enzimas (figura 19).
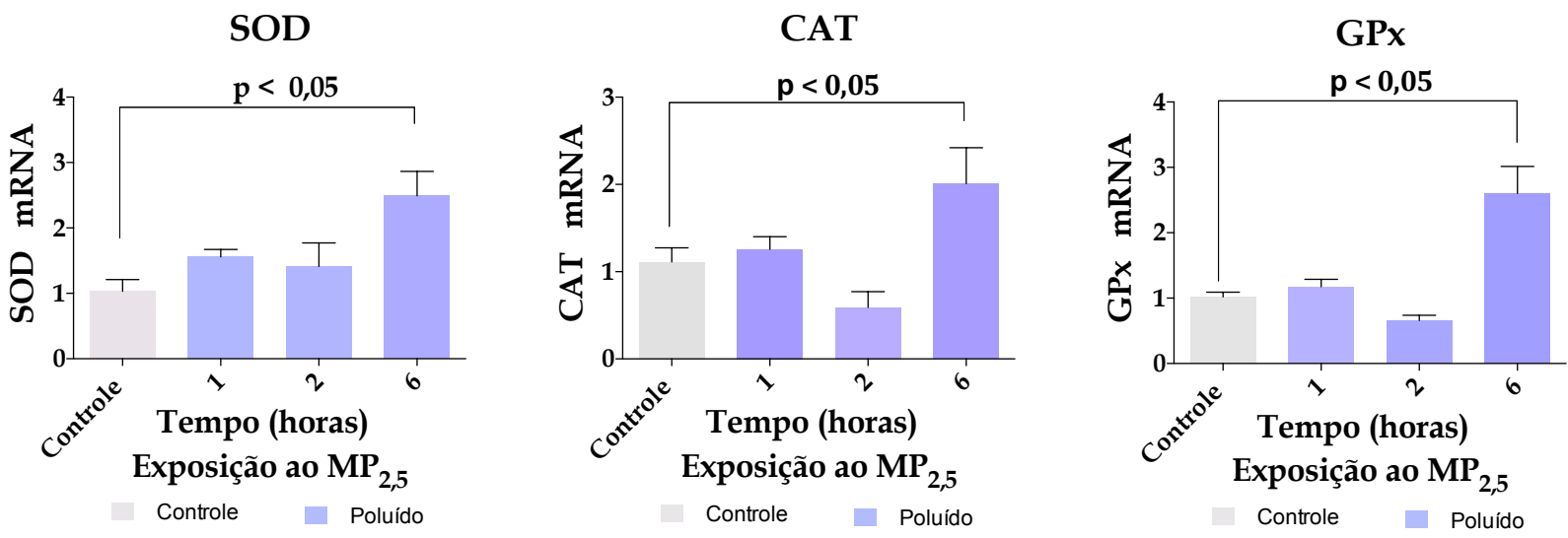

Figura 18 - Efeito da exposição ao material particulado fino (MP 2.5 ) na transcrição do RNAm das enzimas antioxidantes SOD, CAT e GPx. As concentrações do RNAm das enzimas antioxidantes dos pulmões de ratos expostos ao MP ${ }_{2,5}$ e controle foram determinados por RT-PCR em tempo real. Os valores foram normalizados em relação aos pulmões dos ratos controle não expostos à poluição. Os dados estão expressos como a média \pm e.m.p., $n=4-7$ animais. Significativamente diferente $(p<0,05)$ vs grupo controle. 
Em seguida, examinamos o efeito do material particulado nas atividades das enzimas antioxidantes, pois além da sua expressão gênica estar aumentada, seria importante mensurar se a sua capacidade de catalisar também estaria alterada. Os resultados indicaram que a enzima superóxido desmutase (SOD) que faz a conversão do superóxido em peróxido de hidrogênio (Figura 20 A), que é o substrato para as demais, tem a sua atividade aumentada em 3,23 vezes na primeira hora da exposição, nas demais ela retorna aos níveis do controle. Enquanto que as enzimas catalase (CAT) e glutationa peroxidase (GPx) tem um aumento de 1,51 e 2,25 vezes respectivamentes na sua atividade a medida que aumenta o tempo de exposição ao particulado, como se o peróxido de hidrogênio gerado no primeiro momento tivesse que ser consumido pelas enzimas que fazem a conversão desta molécula em água e oxigênio, como a CAT e a GPx (figura 20 B).

\section{A}

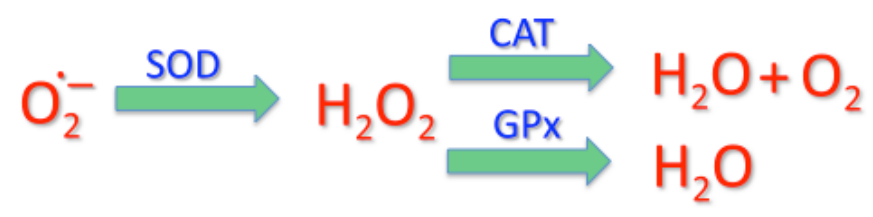

B
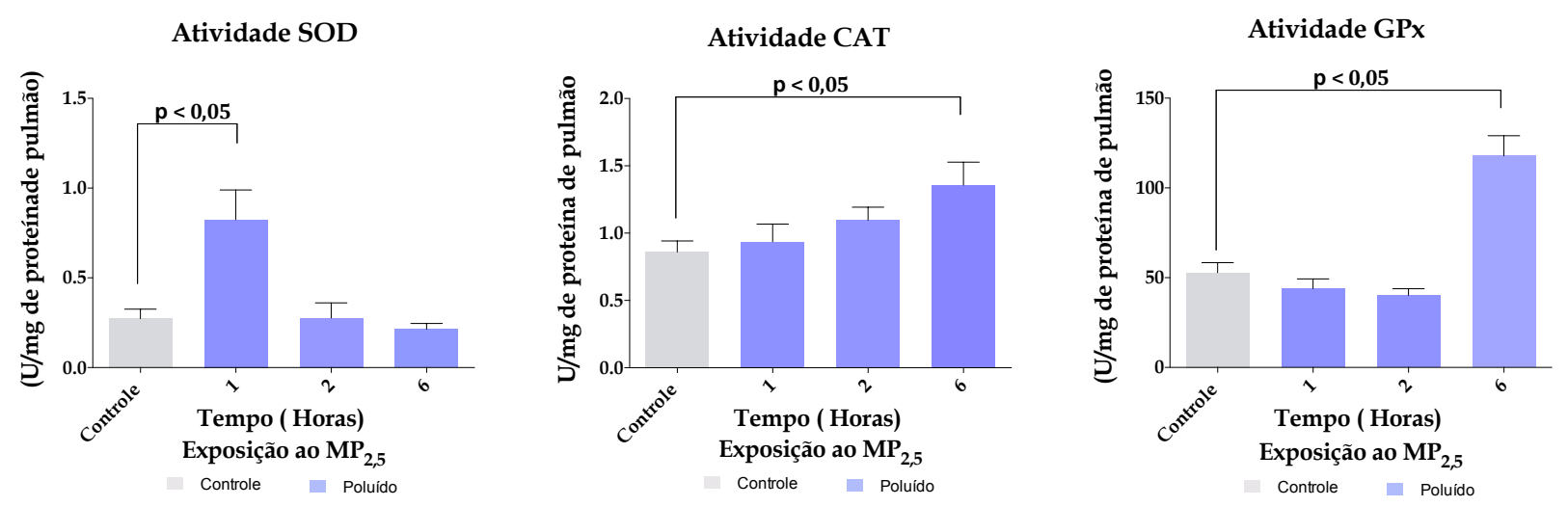

Figura 19 - Efeito da exposição ao material particulado fino (MP ${ }_{2,5}$ ) na atividade das enzimas antioxidantes SOD, CAT e GPx. A - Esquema das reações catalíticas das enzimas antioxidantes. B - Os gráficosdas atividades enzimáticas foram determinadas por espectrofotometria. Os dados estão 
expressos como a média \pm e.m.p., $n=6-10$ animais. Significativamente diferente $(p<0,05)$ vs grupo controle.

\subsection{Melatonina produzida no pulmão ativa receptores próprios para regular as enzimas oxidantes}

Conforme mencionado no item 1.2.2., a melatonina apresenta propriedades antioxidantes, sendo supostamente esta a razão pela qual ela passa a ser produzida localmente na área da injúria. Além desta molécula reagir diretamente com espécies reativas de oxigênio e nitrogênio, os metabólitos gerados pela sua oxidação pelos radicais livres, também apresentam tais propriedades. Inúmeros estudos documentam a relação entre as enzimas antioxidantes e a melatonina sugerindo ainda que esta indolamina atua de forma indireta, via receptor na modulação das mesmas (MAYO et al., 2002; PABLOS et al., 1997).

Portanto, para verificarmos qual o efeito desta indolamina produzida localmente nas enzimas antioxidantes, bloqueamos os receptores de melatonina $\mathrm{MT}_{1}$ e $\mathrm{MT}_{2}$, presentes nos pulmões (Ishii et al., 2009) com seu antagonista luzindol (administrado via i.p. nas doses - 1, 3, 10 e $100 \mu \mathrm{g} / \mathrm{Kg}$ ). Tanto a enzima SOD quanto a CAT tiveram suas expressões gênicas reduzidas em $72,3 \%$ e $84,5 \%$, respectivamente com $100 \mu \mathrm{g} / \mathrm{kg}$ de luzindol, após exposição ao material particulado fino, enquanto que nenhum efeito foi observado sobre a transcrição do gene da GPx (figura 21). Este dado in vivo contribui com o postulado de que a melatonina é um potente modulador do estado redox celular, uma vez que comprovadamente aje modulando as enzimas superóxido dismutase e catalase pulmonar. 

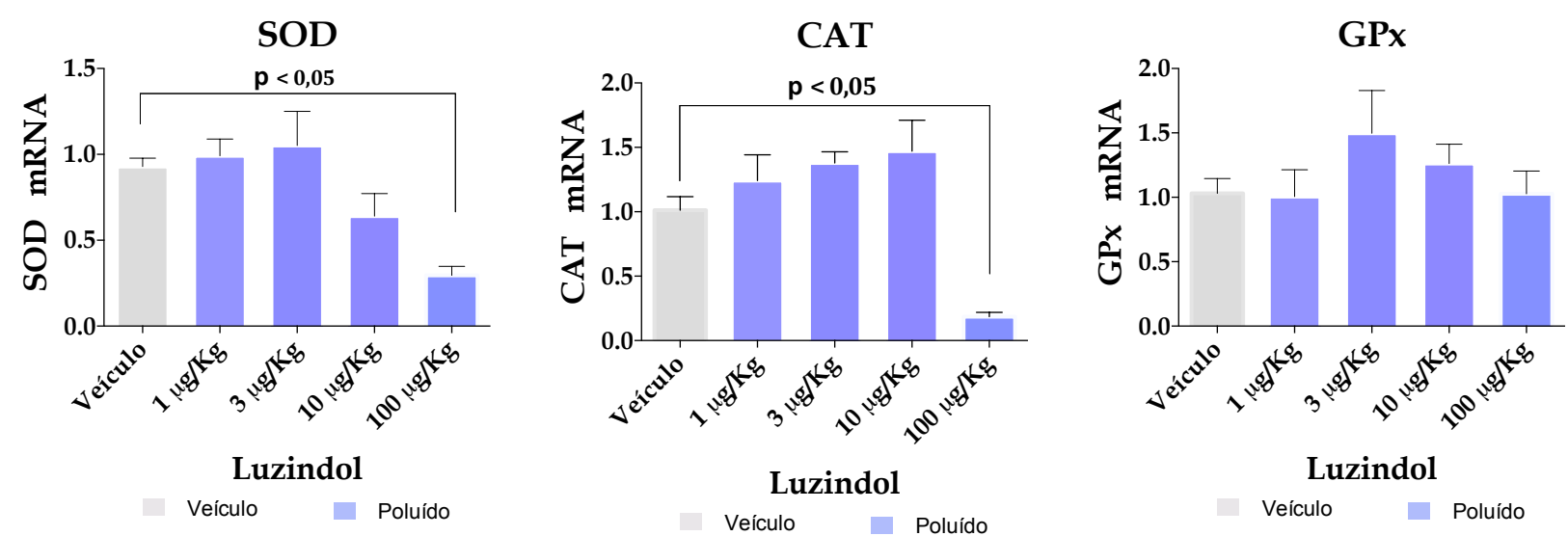

Figura 20 - Efeito da melatonina na expressão gênica das enzimas antioxidantes SOD, CAT e GPx presentes no pulmão após exposição ao material particulado fino ( $M P{ }_{2,5}$ ). As concentrações do RNAm das enzimas antioxidantes dos pulmões de ratos expostos ao MP ${ }_{2,5}$ e controle foram determinados por RT-PCR em tempo real. O bloqueio dos receptores $M_{1} T_{1}$ e $M T_{2}$, formam feitos via i.p. com o antagonsita, luzindol nas concentrações 1, 3, 10 e $100 \mu \mathrm{g} / \mathrm{kg}$. Os valores foram normalizados em relação aos pulmões dos ratos veículos, também expostos à poluição. Os dados estão expressos como a média \pm e.m.p., $n=5-6$ animais. Significativamente diferente $(p<0,05)$ vs grupo veículo.

\subsection{Efeito do luzindol após exposição aguda in vivo ao material particulado fino $\left(\mathrm{MP}_{2,5}\right)$ sobre o estresse oxidativo, sobre a produção de melatonina pela pineal e pelo pulmão}

As enzimas antioxidante provém um importante mecanismo de defesa contra os danos causados por radicais livres por transformá-los em espécies menos reativas ou sub produtos não tóxicos. Para validar a razão pela qual a melatonina é produzida localmente no pulmão em condição de injúria, utilizamos novamente o antagonista luzindol, administrado via i.p., nas doses - 1, 3, 10 e 100 mg/kg.

Verificamos que com a concentração de $100 \mu \mathrm{g} / \mathrm{kg}$, ou seja, onde os receptores $M_{1}$ e $M T_{2}$ estão completamente bloqueados, registramos uma aumento significativo do estresse oxidativo pulmonar de 1.371,00 \pm 97,59 pM MDA /mg de pulmão, enquanto que os pulmões dos animais veículos apresentaram $348,70 \pm$ 22,19 pM MDA /mg de pulmão (figura 22 A). Tal resultado se explica uma vez que o veículo não teve os seus receptores melatoninérgicos bloqueados, portanto a melatonina não foi impedida de se ligar e consequente modular as enzimas SOD e CAT. Valores semelhantes foram apresentados pelas demais doses, já que estas não são capazes de bloquear os receptores $\mathrm{MT}_{1}$ e $\mathrm{MT}_{2}$. 
Pela ativação do eixo-imune pineal, após a exposição noturna de seis horas ao material particulado fino, onde a melatonina plasmática foi reduzida e a pulmonar aumentada (Figura 22B e 22C, respectivamente), constatamos que mesmo com a indolamina acrescida do pulmão frente ao estimulo do poluente, esta fica impedida de regular as enzimas SOD e CAT e desta forma reduzir a peroxidação lipídica.
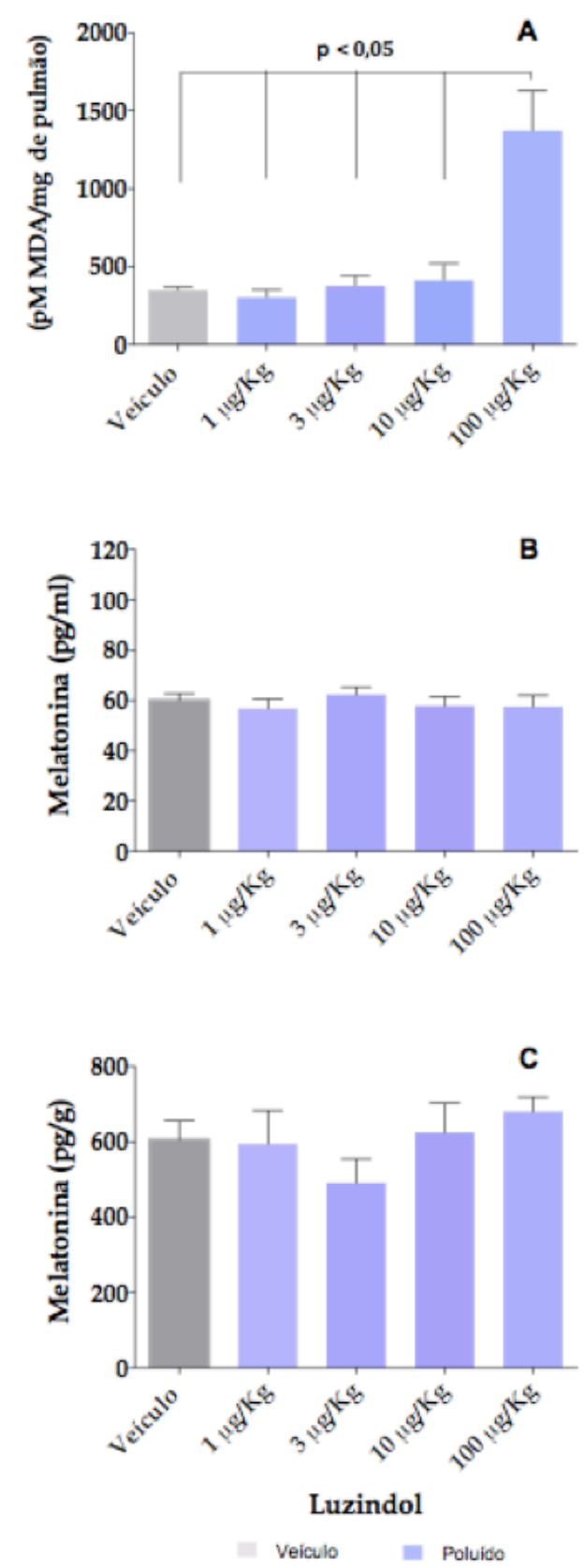

Figura 21 - Efeito do luzindol após exposição aguda in vivo ao material particulado fino $\left(\mathrm{MP}_{2,5}\right)$ sobre : A - O estresse oxidativo. B - A produção noturna de melatonina pela pineal. C Aprodução noturna de melatonina pelo pulmão. Os estresses oxidativos foram determinados por TBARS, e as concentrações plasmáticas e pulmonares de melatonina foram determinadas por ELISA 
$(\mathrm{pg} / \mathrm{ml})$ e $(\mathrm{pg} / \mathrm{g})$. Os dados expressos como a média \pm SEM, $\mathrm{n}=5-7$ animais por grupo. Significativamente diferente $p<0,05$ vs grupo veículo.

\subsection{Efeito do material particulado fino $\left(\mathrm{MP}_{2,5}\right)$ a curto, médio e longo prazo sobre o estresse oxidativo, sobre a produção de melatonina pela pineal e pelo pulmão após exposição aguda in vivo}

Com a evidenciação da instalação do eixo imune-pineal em modelo de exposição aguda à poluição atmosférica urbana da cidade de São Paulo, gostaríamos de investigar se os níveis de melatonina plasmática e pulmonar seriam restabelecidos com a retirada do fator inflamatório ou seja, estimaríamos o tempo para o restabelecimento da regularidade da síntese hormonal de melatonina pela glândula pineal e pelos pulmões após o término da exposição.

Ao final da exposição ao material particulado fino (tempo 0) detectou-se um aumento na geração do estresse oxidativo, passando de $274,70 \pm 38,49$ pM MDA/mg de pulmão (animais controle) para 557,60 \pm 44,84 pM MDA/mg de pulmão (animais poluídos) e ainda 24 horas após o término da exposição, a diferença significativa entre os animais controles e poluídos ainda persistia, fato não mais observado em 72 horas. Portanto, mesmo com a interrupção do estímulo, ou seja da do término exposição à poluição atmosférica, esta ainda gerava danos teciduais.

Respondendo a esta injúria, no tempo 0 , a concentração plasmática de melatonina era de $77,62 \pm 8,07 \mathrm{pg} / \mathrm{ml}$ ( 46,4\% inferior a seu controle) (23B) enquanto que a pulmonar, $834,20 \pm 45,56 \mathrm{pg} / \mathrm{g}$ de pulmão ( $57,6 \%$ superior ao seu controle) (23C), caracterizando a instalação do eixo-imune pineal, porém em apenas 24 horas depois do término da exposição ao poluente estes índices se igualaram aos seus respectivos controles, ou seja, animais não poluídos. Apesar da média da melatonina pulmonar se manter alta $(901,00 \pm 166,91 \mathrm{pg} / \mathrm{g})$ após 24 horas ela não é significativamente diferente do seu controle. 

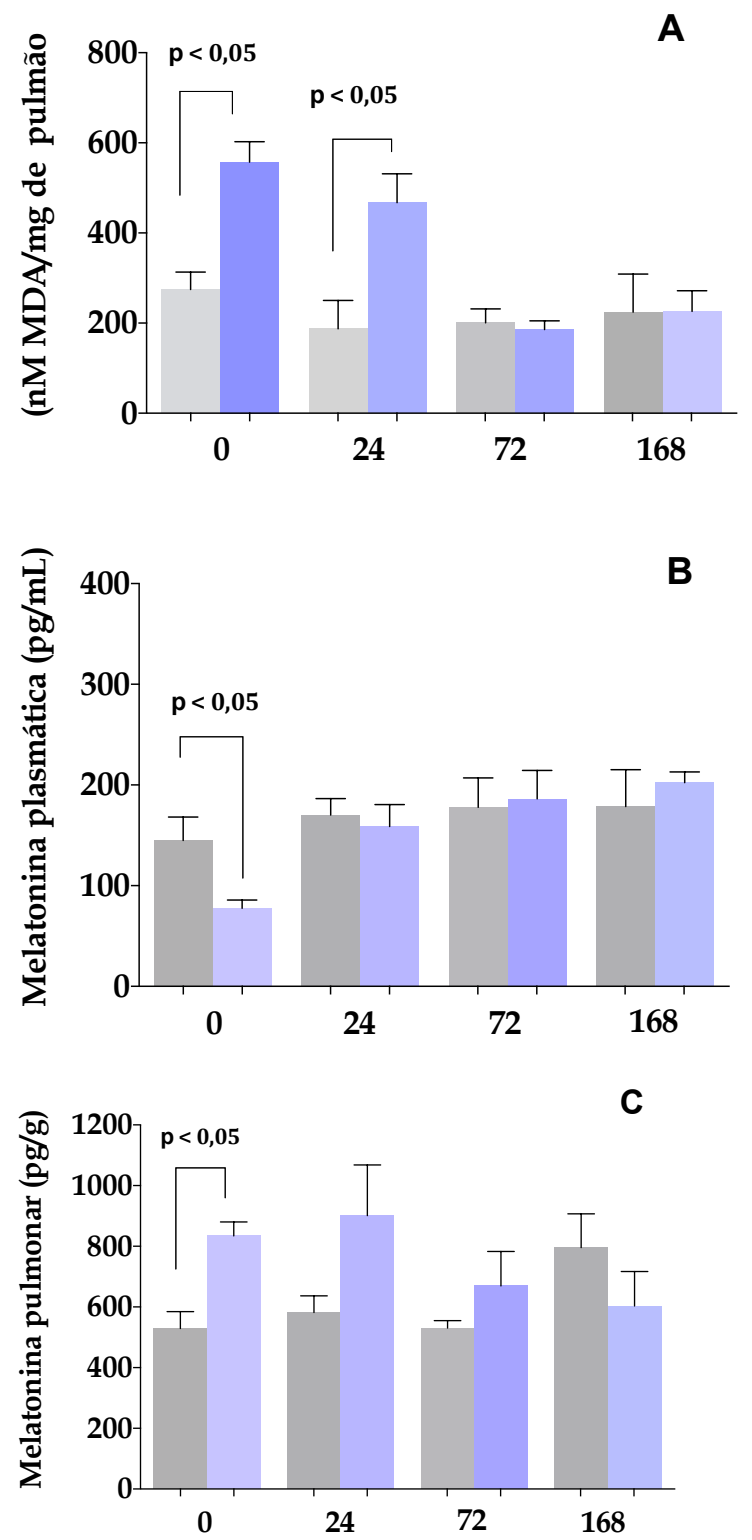

Tempo após o término de exposição ao $\mathrm{MP}_{2,5}$ (horas)

- Controle Poluído

Figura 22 - Efeito do material particulado fino $\left(\mathrm{MP}_{2,5}\right)$ após exposição aguda in vivo, em curto, médio e longo prazo, sobre : A - O estresse oxidativo. B - Aprodução noturna de melatonina pela pineal. C - Aprodução noturna de melatonina pelo pulmão. Os estresses oxidativos foram determinados por TBARS, eas concentrações plasmáticas e pulmonares de melatonina foram determinadas por ELISA (pg/ml) e (pg/g). Os dados expressos como a média $\pm \mathrm{SEM}, \mathrm{n}=3-5$ animais por grupo. Significativamente diferente $p<0,05$ vs grupo controle. 
Discussão 


\section{DISCUSSÃO}

Neste trabalho, demonstramos que a poluição atmosféricas de São Paulo altera o sistema melatonérgico, gera uma resposta inflamatória local e sistêmica o que resulta na supressão da produção noturna de melatonina (endócrina) e leva a um aumento da sua produção local pelo pulmão (autócrina/parácrina), caracterizando assim o eixo imunepineal. A partir deste estudo foi possível verificar que existe uma concentração basal desta indolamina nos pulmões dos ratos naives e controles independente da hora do dia, com caráter de proteção, tal fato é devido ao órgão fazer uma interface entre o meio externo e interno, tendo contato com uma grande variedade de contaminantes e elementos distintos que estimulam o sistema de defesa. Este estudo ainda abre novas perspectivas com relação ao uso terapêutico da melatonina, uma vez que esta indolamina endógena modulou positivamente, as enzimas antioxidantes através da ligação de alta afinidade com seus receptores de membrana acoplados a proteína $\mathrm{G}$, $\mathrm{MT}_{1}$ e $\mathrm{MT}_{2}$.

O modelo experimental adotado pelo presente estudo é diferenciado, uma vez que até a presente data, mais de $90 \%$ dos artigos referentes à poluição utilizam cultura de células e poluentes extraídos do ambiente, recuperados e até mesmo artificiais. Dificilmente, dispomos de estudos que abordam a exposição in vivo ao material particulado fino proveniente de um ambiente urbano como a cidade de São Paulo, lar de 22 milhões de habitantes. Os experimentos existentes in vivo e publicados trazem protocolos, onde se realizam previamente uma instilação nasal ou intratraqueal no animal ou ainda uma inalação forçada descaracterizando desta forma o mecanismo natural da respiração e do contato real do organismo com a poluição do ar e seus componentes, onde os animais respiram livremente a poluição.

Várias são as dificuldades adicionais para extrapolar resultados obtidos in vitro para uma condição in vivo. Os diversos tipos celulares usados como modelo não mimetizam a interação existente nos tecidos vivos, além disso, partículas recuperadas do meio ambiente ou artificiais não representam a complexidade do meio atmosférico. Portanto, uma singularidade do modelo experimental adotado por esta tese foi a possibilidade em retratar in vivo de forma fidedigna, a interação do material particulado e do ar filtrado com o organismo além da inalteração das características dos poluentes. É importante registrar que ainda fez parte integral do modelo experimental um controle 
(naive) que não entrava na câmara de inalação, visto que esta condição poderia ser estressante para o animal.

Comparando os animais expostos ao ar filtrado com os mantidos na mesma sala, porém fora da câmara de exposição (naive) observou-se um aumento da concentração plasmática de corticosterona (30 minutos) seguido de um aumento significativo da concentração de melatonina (1 hora). Este mesmo perfil temporal foi seguido pelos animais expostos ao ar poluído. Os dados sugerem que o ambiente da câmara de exposição gera uma ativação do eixo HPA (hipotálamo-pituitária-adrenal), promovendo o aumento de corticosterona. Este dado fortalece os dados da literatura que comprovam a existência da relação entre as glândulas adrenal e pineal (FERNANDES et al., 2009; LOPES et al., 2001). Essa relação foi demonstrada em situações de inflamação crônica (LOPES et al., 2001) e o efeito potenciador de corticosterona sobre a pineal foi verificado in vitro e in vivo (FERNANDES et al., 2009; FERREIRA et al., 2005).

Considerando que o efeito de corticosterona na presença de uma alta estimulação catecolaminérgica, observada em situações de grande estresse, leva a uma redução da síntese de melatonina (FERNANDES et al., 2016), nossos dados sugerem que a câmara de exposição é uma situação de estresse moderado semelhante à observada com uma leve contensão do animal (COUTO-MORAES et al., 2009). Portanto, o modelo utilizado nesta tese demonstra que uma ativação inicial do eixo HPA resulta num aumento da concentração de melatonina plasmática que retorna a níveis basais apenas nos animais expostos ao ar filtrado. Após 2 horas de exposição ao ar poluído foi observada uma redução significativa da concentração plasmática de melatonina, indicando que este é um fenômeno independente da resposta de estresse. Neste contexto fomos avaliar a possibilidade da poluição também desencadear o eixo imune-pineal.

A região metropolitana de São Paulo possui, atualmente, mais de duas mil grandes indústrias e uma frota superior a sete milhões de veículos, dos quais $6,5 \%$ são de veículos pesados, movido a diesel, e 93,5\% são veículos leves. A poluição do ar na cidade de São Paulo, assim como na maioria dos grandes centros urbanos, é uma mistura complexa de compostos de toxidade variável e em sua maioria são originados pelo tráfego de veículos automotores (CETESB, 2014).

Tais dados vão ao encontro da caracterização do material particulado fino utilizados em nossos experimentos, onde comprovamos uma presença maciça de 
poluentes como os metais presentes nos combustíveis veiculares além de produtos oriundos da sua combustão (compostos orgânicos) e ainda endotoxinas.

Embora o mecanismo que relacione o material particulado aos efeitos nocivos à saúde sejam ainda pouco compreendidos e explorados, evidências comprovam que muito das consequências deletérias podem advir do estresse oxidativo iniciado por componentes químicos presentes no material particulado e que geram espécies reativas de oxigênio e nitrogênio nas células afetadas, levando a um desequilíbrio redox desencadeando uma cascata de eventos associados à inflamação e morte celular (GHIO et al., 2012). De acordo com os elementos químicos encontrados neste trabalho, estes são passíveis de desencadear tais reações, como o ferro, por exemplo, que é o catalisador da reação de Fenton conhecida por gerar o radical hidroxil, um dos mais reativos, a partir de peróxido de hidrogênio. O material particulado fino utilizado em nosso projeto e sua composição foi capaz de gerar um estresse oxidativo pulmonar. Pudemos comprovar esta suposição a partir da quantificação do malondialdeído (MDA), produto resultante da peroxidação lipídica.

Vários autores também chegaram a esta conclusão, como Madden et al. (1999), (1) após a instilação traqueal em ratos de vanádio $(\mathrm{V})$, níquel (Ni) e ferro (Fe), bem como (2) a inalação de metais pesados em pulmões de camundongos por Kadiska et al. (1997), ou (3) a exposição aos compostos orgânicos nos pulmões de roedores de Rhoden et al. (2004, 2005), e ainda (4) a instilação intratraqueal em ratos do produto da exaustão do diesel (DEP) e posterior coleta do lavado brônquio-alveolar (ARIMOTO et al., 2005), onde todos foram capazes de observar a geração de espécies reativas oxigênio. Os mesmos resultados foram encontrados no trato respiratório quando o poluente utilizado foi o carbono elementar (LI et al., 2004, MUDWAY et al., 2004, ZHAO et al., 2009). Uma outra informação é a presença do estresse oxidativo em pulmão de humanos após exposição a poluição atmosférica (CALDERON-GARCIDUENS et al., 1999, CHUANG et al., 2007, REN et al., 2010, ROMANO et al,. 2000, WEI et al., 2009).

A comprovação da presença de endotoxinas no material particulado fino utilizado neste trabalho, ou seja de um PAMP, retrata um notório agente desencadeador de processos inflamatórios das vias aéreas (BECKER et al.,1996, 2003; DONG et al., 1996. LONG et al., 2001). Por esta razão, vários artigos atestam que o material particulado sinaliza principalmente através de receptores TLR4 e TLR2 (BECKER et al., 2002; LUCAS; MAES, 2013). Alguns artigos demonstram que o efeito pro-oxidativo e/ou 
inflamatório do material particulado de diferentes origens é perdido quando há um bloqueio desses dois receptores (BECKER et al., 2005).

Em resumo, os componentes orgânicos, como hidrocarbonetos policíclicos aromáticos ou inorgânicos, como os metais pesados presentes no material particulado fino presentes na poluição atmosférica urbana de São Paulo exercem seus efeitos imunoestimulatórios e tóxicos através da geração de espécies reativas de oxigênio e nitrogênio, enquanto que a sua composição biológica induz respostas inflamatórias envolvendo receptores para padrões moleculares associados aos patógenos, portanto, ambas as fontes desencadeiam um estresse oxidativo e uma resposta inflamatória no tecido pulmonar.

Neste projeto, foi observado que a ativação da via do NF-kB no pulmão pelo material particulado fino leva a um aumento no conteúdo nuclear dos dímeros p50-p50 e p50- RelA. Sabe-se pela literatura que as subunidades de NF-кB RelA, Rel B e cRel possuem o domínio de transativação (TAD), o que as permite atuar como ativadores da transcrição gênica, promovendo a expressão dos genes-alvos quando ligados aos sítios КB presentes nas sequências promotoras. Já as subunidades p50 e p52, por não possuírem o TAD, podem atuar de duas formas distintas: como repressoras da transcrição gênica, quando estão sob a forma de homodímeros; ou ativadoras da transcrição, quando formam heterodímero com uma das subunidades que apresentam TAD (GHOSH; HAYDEN, 2008).

Pelo exposto acima, os dímeros de NF-кB (p50-p50 e p50-RelA), que são ativados pelo material particulado fino no pulmão provavelmente devem atuar sobre genes-alvos distintos. O aumento em p50-RelA relaciona-se com a indução da transcrição gênica de outros alvos, como o gene da citocina TNF- $\alpha$ e da enzima iNOS pulmonar (O'NEILL; KALTSCHMIDT, 2007) ambas detectadas e registradas neste projeto ou ainda das enzimas antioxidantes SOD, CAT e GPX conforme relatado por ZHOU et al. (2001) em células musculares esqueléticas de camundongos sob o estresse oxidativo.

A translocação nuclear do NF-אB pela ativação dos receptores TLRs pelo material particulado é bem documentada, com a maioria dos estudos envolvendo linhagens celulares epiteliais pulmonares in vitro. Alguns trabalhos demonstram que a ativação do $\mathrm{NF}-\kappa \mathrm{B}$ pelo material particulado é dependente da produção de espécies reativas de 
oxigênio (CHURG et al., 2005; DAGHER et al., 2007; GLOIRE et al., 2006; ISHII et al., 2004; KENNEDY et al., 1998, KIM et al., 2005; QUAY et al., 1998; SHUKLA et al., 2000).

Ainda neste trabalho, a ativação do NF-אB pulmonar pelo material particulado fino ainda que com pouco tempo de exposição, comprova que este poluente está agindo de maneira comum aos outros sinalizadores da resposta imunidade inata, gerando os componentes da resposta inflamatória, como as moléculas de adesão (PECAM-1 e ICAM-1) e a enzima sintase de óxido nítrico induzida (iNOS), além de citocinas próinflamatórias como TNF- $\alpha$, IL-1 $\alpha$ e $\beta$, IL-6, e enzimas antioxidantes SOD, CAT e GPx.

Os estudos com material particulado, que consideram as respostas de exposições agudas à poluição, obtidos após 2, 6 e 20 horas (VAN BERLO et al., 2010), em um dia (NEMMAR et al., 2005), com 15 dias (CAMPBELL et al., 2005) e em um mês (GERLOFS-NIJLAND et al., 2010; VAN EEDEN et al., 2001) revelam que a ativação do $\mathrm{NF}-\kappa \mathrm{B}$, leva a indução de citocinas pró-inflamatórias no plasma, tais como TNF- $\alpha$ e IL$1 \beta$, GM-CSF, a expressão da iNOS e COX2.

Histologicamente, também comprovamos a inflamação local pulmonar com características peculiares de uma resposta aguda e inata à poluição atmosférica urbana após exposição in vivo, com a migração de fagócitos mononucelares e polimorfonucleares para os brônquios, redução do lúmen deste órgão bem como do espessamento da musculatura lisa.

O material particulado além de induzir a resposta imune inata, pode ainda ultrapassar as barreiras de proteção pulmonar e até mesmo a hematoencefálica e gerar além de respostas locais, respostas sistêmicas através de efeitos diretos (BLOCK; CALDERÓN-GARCIDUENAS, 2009). Estudos com partículas (5 e 100 nm) de carbono e prata marcadas radioativamente demonstraram que essas são translocadas para a circulação e detectadas já em 5 minutos após inalação ou instilação (NEMMAR et al., 2001; TAKENAKA et al., 2001). Além disso, tem sido demonstrado que as nanopartículas inaladas podem chegar ao cérebro (ELDER et al., 2006; OBERDORSTER et al., 2004), possivelmente através do epitélio nasal olfativo translocando ao longo do nervo olfatório ou diretamente por deposição sobre os espaços alveolares cruzando a barreira epitelial do pulmão e a barreira hematoencefálica (OBERDORSTER et al., 2004, PETERS et al., 2006), portanto o material particulado pode gerar uma inflamação local e/ou sistêmica.

Inalação ou instilação de partículas de poluição estimulam a produção de mediadores inflamatórios tanto por leucócitos obtidos de um lavado brônquio-alveolar 
quanto de células epiteliais do trato respiratório. A mesma atividade pode ser obtida por modelos de linhagens de células imunocompetentes expostas a estas partículas. (BECKER et al., 2003; FUJIl et al., 2001; LI et al., 2002; OSORNIO-VARGAS et al., 2003; VAN EEDEN et al., 2001).

Nesta tese utilizando o modelo de inalação observamos a presença de citocinas no plasma o que indica uma reação pró-inflamatória de origem pulmonar. Esta variação foi específica para cada grupo de citocinas, algumas apresentaram variações transientes, enquanto outras, o efeito foi duradouro. Entre as transientes destacamos o

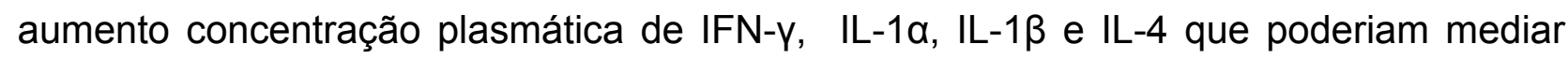
migração leucócitária, ativação dos macrófagos e modulação de resposta linfocítica (BECKER et al., 2002, 2003 e 2005, MIYATA; VAN EEDEN, 2011). A concentração IL-6 e TNF- a no plasma mantiveram-se elevada a partir da primeira avaliação (30 min.). Vale ressaltar que o aumento de IL-6 é considerado um biomarcador de resposta inflamatória resultante da exposição à poluição atmosférica (Brook et al., 2010). Neste trabalho, apenas com meia hora de exposição ao material particulado fino, a concentração plasmática do TNF- $\alpha$ apresentou um aumento significativo e este acréscimo foi acompanhado por todo tempo da exposição. O aumento de TNF no plasma tem sido sugerido como um desencadeador do eixo imune-pineal e portanto coincide com diminuição da concentração de melatonina plasmática no período noturno. A glândula pineal está aparelhada para reconhecer esta citocina já que na membrana dos pinealócitos foram detectados receptores para TNF do subtipoTNFR1 (CARVALHOSOUSA et al., 2011). A estimulação destes receptores produz a translocação nuclear de $N F-\kappa B$, inibição da transcrição do gene que codifica a AA-NAT e, portanto a síntese de melatonina (FERNANDES et al., 2006). Interessante observar que outros fatores que

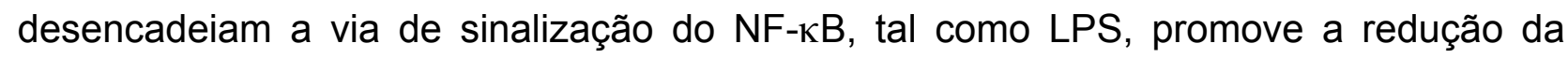
síntese de melatonina (CARVALHO-SOUSA et al., 2011; DA SILVEIRA CRUZMACHADO et al., 2010, TAMURA et al., 2010). Esta redução, inclusive, é mediada pela produção de TNF pela microglia residente na glândula pineal (DA SILVEIRA CRUZMACHADO et al., 2012). Vale a pena registrar que o material particulado aumenta a atividade do NF-кB na pineal e a inibição da transcrição do gene que codifica a AA-NAT sendo este um fator relevante para a supressão da síntese de melatonina (CARVALHOSOUSA, 2015). No mesmo trabalho foi demonstrado in vitro que o DEP leva a produção de TNF pela pineal. 
Em humanos foi observado uma correlação altamente significante entre a concentração plasmática noturna de TNF e de melatonina em condições de inflamação abiótica (DE OLIVERIA TATSCH-DIAS et al., 2013; PONTES et al., 2006, 2007). Mulheres que desenvolveram inflamações não infecciosas como mastite ou inflamações pós-cirúrgicas apresentaram altos níveis circulantes de TNF e a abolição do ritmo diário de melatonina. A restauração da ritmicidade diária de melatonina coincidiu com concentrações não detectáveis de TNF no plasma. Além disso, em casos de sepses que é sempre acompanhada de altos níveis de TNF circulante, ocorre a supressão do ritmo diário de melatonina (MUNDIGLER et al., 2002).

Estes dados justificam a redução da concentração plasmática noturna de melatonina advinda da pineal após a exposição aguda de seis horas ao poluente atmosférico obtidas no nosso estudo. Tal decréscimo possivelmente, foi em decorrência da detecção pela pineal do TNF- $\alpha$ produzido pelo pulmão e que migrou para corrente sanguínea, por nós detectado no plasma, ou do poluente que migrou para a circulação e estimulou células imunocompetentes circulantes a produzir esta citocina, ou ainda da identificação do material particulado pela glândula a partir da ativação da microglia e produção local de TNF- $\alpha$. As três possibilidades não se excluem e podem ser sinérgicas. Desta forma, a inibição ou diminuição da via biosintética da melatonina é considerada necessária ao processo de montagem da resposta inflamatória no modelo de inflamação pulmonar induzido por poluição atmosférica, uma vez que o aumento dos seus níveis plasmáticos noturnos de melatonina poderiam levar a uma redução do rolamento e adesão de leucócitos à camada endotelial e migração para os tecidos alvos (MARKUS et al., 2007).

A ativação do eixo imune-pineal também foi registrada neste projeto, uma vez que o aumento na exposição noturna dos animais ao material particulado fino leva a uma redução de $39,0 \%$ na produção da melatonina pela pineal. Sendo que o inverso ocorre nos pulmões, onde o aumento na exposição leva a uma acréscimo de 55,0\% desta indolamina. Esta produção pulmonar acontece mesmo na fase de claro, onde sabidamente, a glândula pineal não produz melatonina, sugerindo fortemente, que o conteúdo de melatonina detectado no pulmão advém de uma produção local. Nesse contexto o material particulado fino surge como um novo fator de injúria capaz de ativar o eixo imune-pineal. A melatonina é uma molécula ímpar que apresenta respostas específicas em inúmeras situações fisiológicas. A redução na síntese da melatonina pela 
pineal é requerida para o engatilhamento do processo da resposta inflamatória, e a sua produção em células de defesa se mostra altamente relevante na resolução da resposta.

Uma outra informação significante é uma concentração de melatonina basal presente nos pulmões dos ratos naives e controles independente da hora do dia com níveis compatíveis aos encontrados nos órgãos do trato gastrointestinal de mamíferos por BUBENIK et al.(1997). Esta produção extra pineal de melatonina no pulmão deve-se possivelmente ao estímulo de células imunocompetentes, como os macrófagos alveolares, essenciais para a remoção de partículas e patógenos inalados presentes nas vias aéreas (HIRAIWA; VAN EEEDEN, 2013; HUSSELL; BELL, 2014). Macrófagos alveolares de ratos ou da linhagem RAW 264.7 expostos a DEP produzem melatonina e esta induz um aumento de viabilidade celular e aumento da capacidade fagocítica (CARVALHO-SOUSA, 2015). As células enterocromafins presentes no trato gastrointestinal que são aparelhadas para a síntese de melatonina (RAIKHIJNN; KVENTNOY, 1976) também estão presentes nos epitélios pulmonares, podendo também contribuir nesta produção. Como o pulmão é a porta de entrada de poluentes, a partir do qual uma resposta sistêmica é deflagrada, nada mais adequado que a presença da melatonina neste órgão como agente regulador de resposta de defesa.

O aumento de evidências nos últimos dez anos tem demonstrado que o macrófago alveolar desempenha um papel chave na resposta inflamatória pulmonar local e sistêmica induzida pelo material particulado. No pulmão, o macrófago alveolar contribui para a magnitude e a natureza da resposta inflamatória através da interação com outras células pulmonares como as células epiteliais brônquicas e dendríticas unindo esforços para processar e limpar o material particulado do pulmão. Este macrófago também produz mediadores que estão associados à resposta inflamatória sistêmica induzida pela exposição ao poluente sendo que estudos recentes fundamentam a hipótese de que estes mediadores sistêmicos translocam do tecido pulmonar para a circulação (HIRAIWA ; VAN EEDEN, 2013). Os macrófagos alveolares produzem uma variedade de mediadores pró inflamatórios incluindo mediadores de resposta aguda como as interleucinas, IL-1 $\beta$ e IL-6 bem como mediadores secundários como o IL-8 e fator de crescimento de colônias de granulócitos-macrófagos (GM-CSF) (HOGG; VAN EEDEN, 2009; VAN EEDEN et al., 2001). Curiosamente, a produção de mediadores anti-inflamatórios como a IL-10 foi suprimida (VAN EEDEN; HOGG, 2002; YIN et al., 2004), sugerindo que a resposta inflamatória do macrófago alveolar é direcionada para um perfil pró-inflamatório. 
E ainda, estudos prévios indicam o macrófago alveolar como a célula chave responsável pela a geração da resposta inflamatória sistêmica associada com a exposição à poluição atmosférica. (HIRAIWA; VAN EEDEN, 2013; REFSNES et al. 2006; SAWYER et al. 2010; VAN EEDEN et al., 2005, 2001).

Confrontando os dados literários levantados e os valores por nós obtidos, podemos supor que os macrófagos alveolares são os condutores da resposta próinflamatória no pulmão após a inalação do material particulado fino em modelo in vivo por nós adotado, sendo estes responsáveis pelo aumento de citocinas pró-inflamatórias TNF- $\alpha$, IL-1 $\beta$, IL-1 $\alpha$, INF- $\gamma$, IL-6, IL-2 e IL-4 detectadas no plasma.

Outros dados do laboratório mostraram ainda que a síntese de melatonina local no cerebelo, é responsável por impedir a morte neuronal induzida pelo LPS (FRANCO; MARKUS, 2014, PINATO et al., 2015). Por esta razão, a capacidade do LPS em induzir a morte foi menos pronunciada no cerebelo do que no córtex e hipocampo, locais que não sintetizam melatonina. Os efeitos citoprotetores da melatonina são mediados por ativação de receptores de alta afinidade, porque o bloqueio dos mesmos aumenta a morte de células no cerebelo.

Todos estes dados exemplificam o efeito citoprotetor desta indolamina sendo uma justificativa para a sua produção local pulmonar após à exposição ao material particulado fino por nós detectado.

Sabendo que o material particulado fino tem alto potencial pró-inflamatório e oxidativo, a melatonina poderia atuar se ligando às espécies reativas de oxigênio (POEGGELER et al., 1996), e/ou modulando enzimas antioxidantes (HARDELAND, 2009; TAN et al., 2002) e também regulando o processo de fagocitose dessas partículas poluidoras (CARVALHO-SOUSA, 2015; MUXEL et al., 2012). Essas ações nos sugere que a melatonina está envolvida na eliminação de partículas do pulmão e redução dos danos oxidativo gerados.

Em sistemas químicos isolados foi demonstrado que além da molécula da melatonina, os seus metabólitos reagem com radicais livres de forma direta ( HARDELAND et al., 2003, 2006; POEGGELER et al., 2002; SILVA et al. 2006).

No entanto, a eficiência da melatonina em reduzir o estresse oxidativo não depende apenas da sua aptidão em doar elétrons, mas principalmente da sua capacidade de interagir em baixas concentrações através dos receptores $M_{1} T_{1}$ e $M_{2}$ aumentando a expressão e a atividade de enzimas envolvidas na detoxificação (MAYO et al., 2002) 
A melatonina atua em enzimas antioxidantes como a superóxido dismutase (SOD) e glutationa peroxidase (GPx), glutationa redutase (GR), catalase (CAT) e glicose 6 fosfato desidrogenase (G6PD), aumentando as suas atividades. Já a 5 e 12 lipoxigenase (5 e 12-LO) tem suas atividades reduzidas (LIU; NG, 2000). A atividade da enzima glutationa peroxidase também é aumentada na presença de melatonina exógena, como observado em cérebros de ratos (BARLOW-WALDEN et al., 1995). A atividade da superóxido dismutase pulmonar e cortical apresentam um ritmo circadiano que é sincrônico à produção de melatonina pela glândula pineal, sendo a atividade da enzima maior na presença de melatonina, sugerindo uma potencialização pela indolamina (ALBARRAN et al., 2001).

Devido as suas propriedades citoprotetoras, a demanda da produção da melatonina no local de injúria visa a rápida resolução do quadro, tentando diminuir os danos e protegendo a integridade celular, por esta razão após a exposição ao material particulado, as expressões gênicas pulmonar das enzimas da AA-NAT e ASMT, as quais participam da biossíntese da melatonina, duplicou e triplicou, respectivamente. Registramos também um aumento na expressão do RNAm das enzimas antioxidantes SOD, CAT e GPx dependente da concentração do material particulado fino, tendo os seus valores dobrados.

As relações entre a melatonina e as enzimas antioxidantes são bastante significativas, segundo Mayo et al. (2002) a melatonina exógena após o tratamento de ratos com a neurotoxina, 6-hidroxidopamina, impediu a depressão da expressão gênica neuronal de GPx e SOD. Igualmente, outros observaram que a melatonina aumenta a expressão gênica das enzimas antioxidantes mesmo a partir de suas condições basais ou após sua inibição por agentes neurotóxicos (ATOLIN, 2002; KOTLER et al., 1998). Ortega-Jimenez-et al. (2009), trataram os animais durante um mês com melatonina na água de beber e registraram o aumento dos mRNAs das enzimas SOD e CAT no hipotálamo dos ratos quando comparadas com os controles.

No nosso trabalho, as atividades destas enzimas também estão alteradas tendo a SOD a sua capacidade de catalisar aumentada na primeira hora de exposição e reduzida nas demais, enquanto que as das CAT e GPx aumentam gradativamente, a medida que o tempo de exposição progride. Estes dados nos remetem às funções de cada uma, ou seja, no primeiro momento a SOD converte o radical livre, superóxido, em peróxido de hidrogênio e as demais enzimas, CAT e GPx o convertem em água e oxigênio. Justificando desta forma, as atividades estarem alteradas em tempos distintos, 
uma vez que a demanda está diferenciada. Os trabalhos de Barlow-Walden et al., (1995) e de Kotler et al., (1998) mostram que as atividades e a expressões gênicas das enzimas antioxidantes no córtex do cérebro de ratos se elevaram após a administração periférica de melatonina.

A melatonina influencia tanto os níveis de RNAm destas enzimas quanto suas atividades quer seja em condições fisiológicas ou sob o estresse oxidativo (RODRIGUEZ et al., 2004). Artigos mostraram que o as atividades das CAT e GPx são extintas quando as galinhas são mantidas sob a luz constante que impede o aumento fisiológico da melatonina (PABLOS et al., 1997). Já o aumento da atividade da GPx em cérebro de ratos (BARLOW-WALDEN et al., 1995) e de galinha (PABLOS et al., 1995) pela administração exógena da melatonina é maior à noite, fase em que esta indolamina está circulando. Tanto em doses únicas quanto diárias a melatonina tem efeito positivo nas atividades das enzimas antioxidantes de rins, fígado e cérebro de ratos conforme apresentado por Liu e Ng, (2000) e Ozturk et al., (2000). Observou-se ainda um efeito pré-natal, onde o aumento da atividade das enzimas GPX e SOD no cérebro dos fetos de ratas prenhes se deu após a administração da melatonina (OKATANI et al., 2000).

Porém, nenhum dos trabalhos anteriormente descritos correlacionando as enzimas antioxidantes e a melatonina abordam o mecanismo de ação pelo qual a indolamina modula estas enzimas. Em nosso estudo atestamos que a melatonina endógena atua em seus receptores acoplados à proteína G (GPCRs), também conhecidos como receptores transmembranares, $\mathrm{MT}_{1}$ e $\mathrm{MT}_{2}$. Estes receptores são de alta afinidade e modularam a transcrição gênica das enzimas antioxidantes SOD e CAT após exposição ao material particulado fino. Após o bloqueio dos mesmos com o antagonista não seletivo, luzindol, registramos uma redução de mais de $70,0 \%$ na transcrição gênica das enzimas antioxidantes e um acréscimo de 392,0\% do estresse oxidativo pulmonar, entendendo que a impossibilidade da ação da melatonina nos seus respectivos receptores de membrana impede a ação das enzimas antioxidantes SOD e CAT. Comprovamos assim, a ação gênica da melatonina via receptor e caracterizamos um alvo farmacológico que atuaria na capacidade do pulmão de se proteger contra os danos gerados pela poluição atmosférica. Portanto, a melatonina pode agir em um sistema de altíssima afinidade que é a interação com os receptores acoplados a proteína G, MT1 e MT2, sendo alvos viáveis no tratamento de enfermidades como a doença pulmonar obstrutiva crônica (DPOC) (DE MATOS CAVALCANTE et al., 2012) e como adjuvante em tratamentos antineoplásicos pulmonares (SHOKRZADEH et al., 2015) 
Um outro fato observado em nosso trabalho foi o período de vinte e quatro horas para o reestabelecimento dos níveis plasmáticos e pulmonares de melatonina após a interrupção da exposição ao material particulado fino. Coincidentemente, este dados somam-se aos obtidos por de Oliveira Tatsch-Dias et al., (2012), onde também foi registrado este mesmo tempo para a restauração dos níveis normais de melatonina plasmática em humanos que sofreram histerectomia. Este pode ser o período de tempo adequado de espera antes de se administrar a melatonina a fim de se evitar a interferência com a montagem da resposta inflamatória inata.

Os resultados obtidos neste trabalho in vivo e resumidos nas figuras 24 e 25 indicam que a exposição aguda à poluição atmosférica gera um estresse oxidativo pulmonar, deflagra uma resposta inflamatória a partir da ativação da via de sinalização do NF-KB, do aumento das moléculas de adesão PECAM e ICAM e da sintase de óxido nítrico induzida (iNOS), bem como de citocinas inflamatórias (TNF- $\alpha$, IL-1 $1 \beta$, IL -1a, IFNY, IL-4 e IL-6). A medida que o tempo de exposição à poluição progride, a concentração plasmática noturna da melatonina se reduz enquanto que a pulmonar aumenta, esta alternância transiente entre a produção central de melatonina, pela pineal, para a produção periférica, por células imunocompetentes formam a base experimental que fundamentam a existência do eixo imune-pineal.

A fim de limitar a inflamação e prevenir danos colaterais a tecido saudáveis, 0 pulmão orquestra formação de mediadores especializados em resolver processos deletérios. Tanto as enzimas AA-NAT e ASMT envolvidas na biossíntese da melatonina, quanto as enzimas antioxidantes SOD, CAT e GPx tem suas expressões gênicas no pulmão duplicadas dependente do tempo de exposição à poluição. Houve também um aumento nas atividades das mesmas, sendo transiente na SOD e crescente nas demais. A melatonina coordena ações citoprotetoras no tecido pulmonar através da sinalização via receptores, uma vez que a peroxidação lipídica local é aumentada quanto estes receptores $\mathrm{MT}_{1}$ e $\mathrm{MT}_{2}$ são bloqueados e as enzimas SOD e CAT impedidas de atuarem.

Por todos os argumentos descritos anteriormente, a produção da melatonina em órgãos que fazem a interface do meio externo com o interno, como pele, trato gastrointestinal (TGI) são a partir de literatura sabidamente produtores desta indolamina independente da hora do dia, portanto, o pulmão passa a fazer parte deste grupo.

Avaliando em conjunto os dados, avalizamos que a melatonina produzida pelo pulmão em resposta ao poluente tem o objetivo de reduzir os danos oxidativos gerados, diminuir a resposta pró-inflamatória e consequentemente redução do dano tecidual. 
Estes efeitos são mediados a partir da interação desta indolamina com receptores acoplados a proteína $\mathrm{G}, \mathrm{MT}_{1}$ e $\mathrm{MT}_{2}$, alvos farmacológicos na atenuação dos efeitos deletérios gerados no pulmão.

Os pesquisadores preveem que nos próximos anos o número de mortes prematuras causadas pela poluição atmosférica será superior às mortes causadas por malária e por falta de saneamento básico. Existem evidencias científicas que correlacionam esta poluição com doenças respiratórias, cardiovasculares e vários tipos de câncer. Raaschou-Nielsin et al., (2013) unificaram dados de mais de 300.000 indivíduos em 9 países e concluíram que o risco de câncer de pulmão no grupo exposto à poluição aumentou em $50 \%$ para cada $10 \mu \mathrm{g} / \mathrm{m}^{3}$ de material fino inalado, retratando desta forma, a poluição do ar como um grave problema epidemiológico mundial. Rodrigues et al., (2015) estimaram que em 14 anos, a poluição atmosférica matará 256 mil pessoas no estado de São Paulo, sendo que neste período haverá 1 milhão de internações hospitalares e um gasto público em saúde de mais de 1,5 bilhões de reais.

Devido à escassez de recursos que mitiguem a poluição atmosférica dos grandes centros urbanos e de leis mais rígidas no controle da emissão de agentes poluentes, se faz necessário o desenvolvimento e a investigação de elementos que possam conter e/ou reverter os efeitos celulares deletérios causados pela poluição do ar, desta maneira, devido as suas propriedades, comprovadas nesta tese, a melatonina e seus análogos seriam uma fortes candidatos a este desafio. 


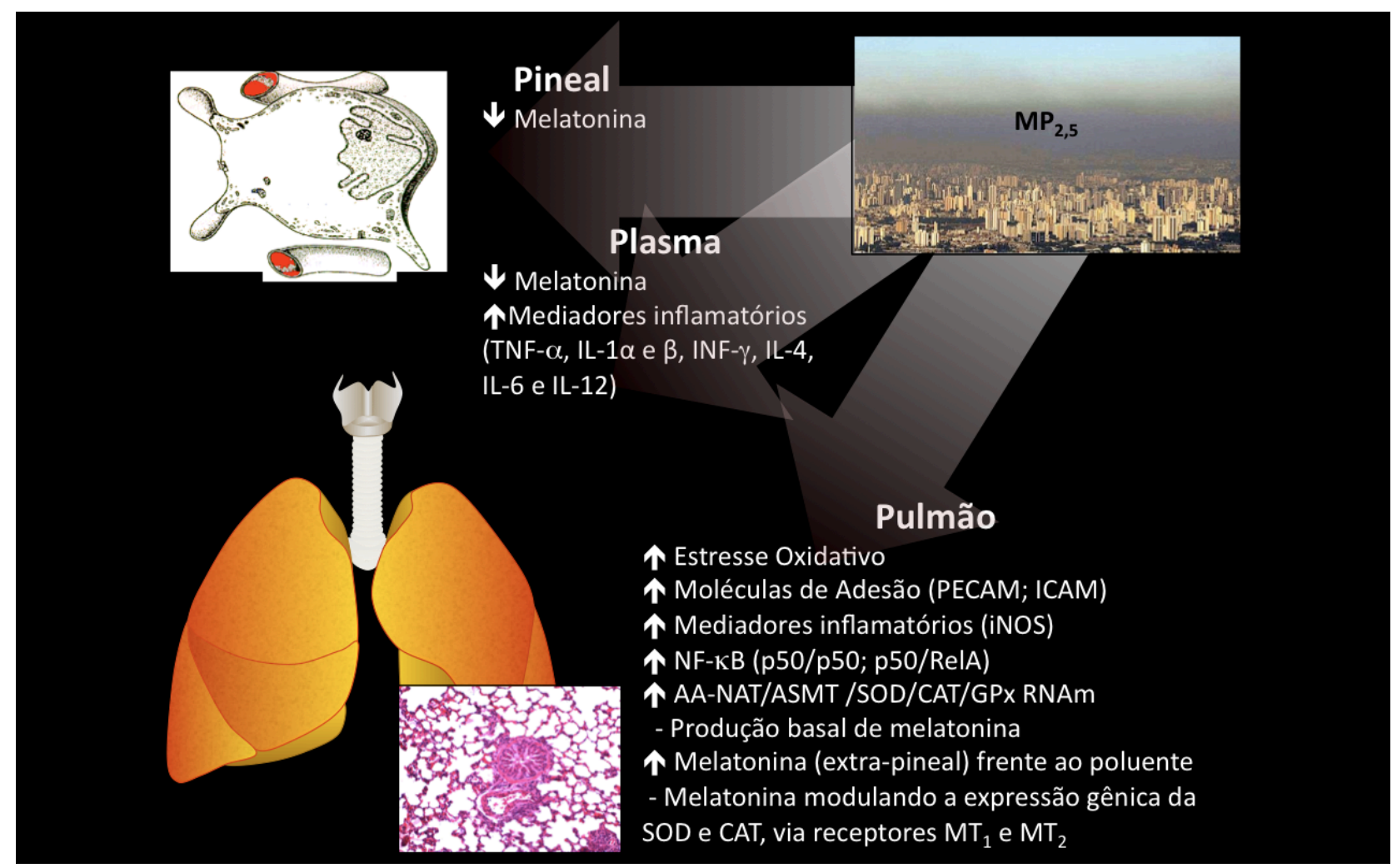

Figura 23 - Resumo ilustrativo dos efeitos desencadeados pelo material particulado fino $\left(\mathrm{MP}_{2,5}\right)$ sobre o pulmão e pineal em modelo in vivo de exposição aguda. Pineal - redução na produção de melatonina; Plasma - redução na concentração de melatonina, aumento de mediadores inflamatórios (TNF- $\alpha$, IL-1 $\beta, I L-1 \alpha$, IFN- $\gamma$, IL-4, IL-6 e IL-12); Pulmão - aumento do estresse oxidativo, ativação do NF$\kappa \mathrm{B}$ (p50/p50 e p50/RelA), aumento de moléculas de adesão (PECAM-1 e ICAM-1) e da sintase de óxido nítrico induzida (iNOS), aumento do mRNA das enzimas AA-NAT, ASMT, SOD, CAT e GPx, produção da melatonina basal, produção extra pineal frente ao estímulo do $\mathrm{MP}_{2,5}$ e melatonina modulando a expressão gênica da SOD, CAT via receptores $\mathrm{MT}_{1}$ e $\mathrm{MT}_{2}$. 


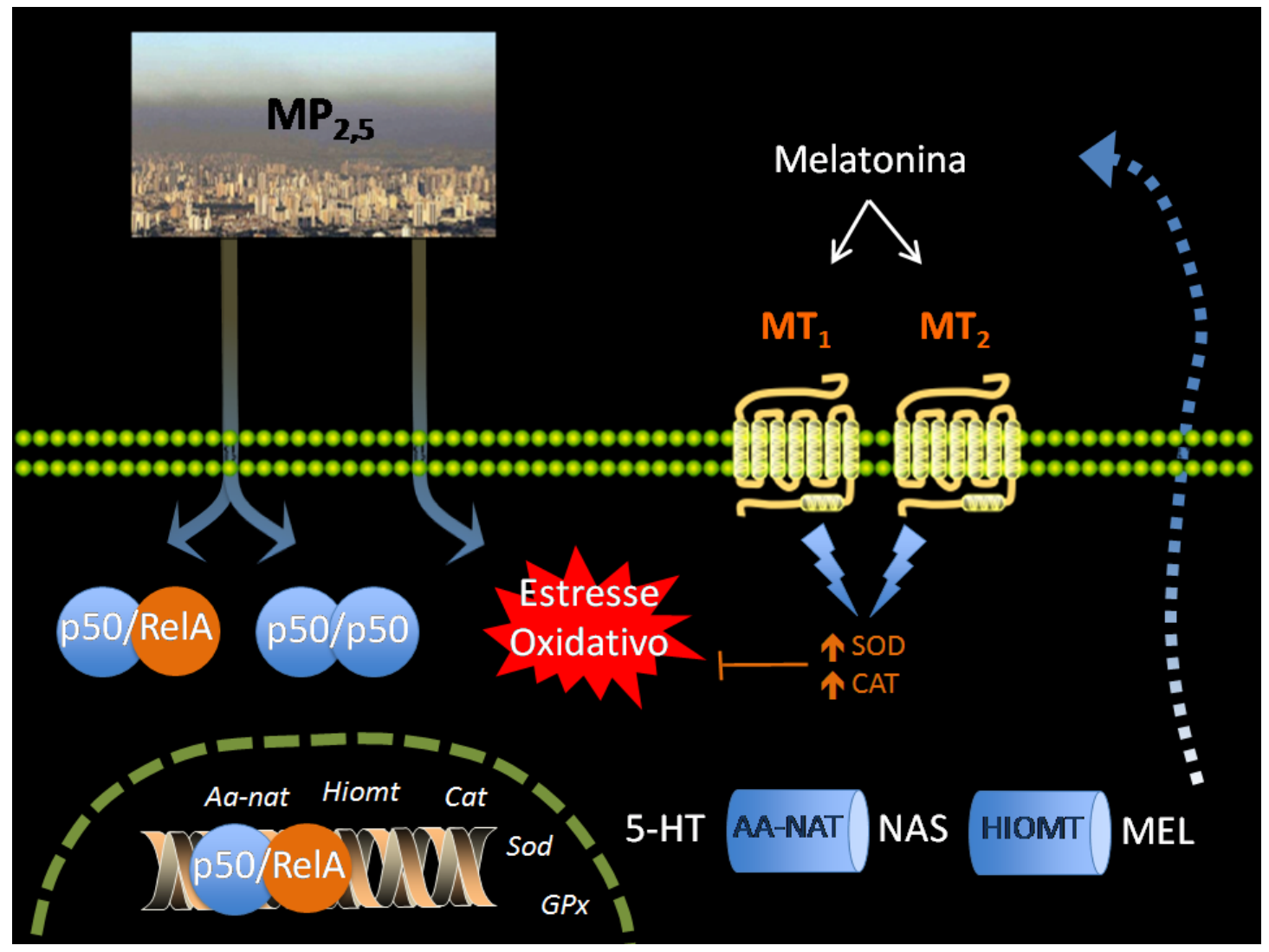

Figura 24 - Esquema ilustrativo do efeito do material particulado fino $\left(\mathrm{MP}_{2,5}\right)$ sobre o pulmão em modelo in vivo de exposição aguda. A poluição atmosférica gera um estresse oxidativo pulmonar,

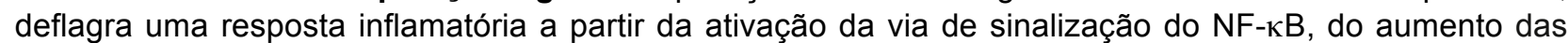
moléculas de adesão PECAM-1 e ICAM-1 e da sintase de óxido nítrico induzida (iNOS), bem como de

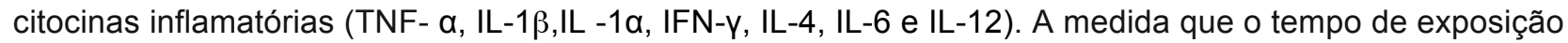
à poluição progride, a concentração plasmática noturna da melatonina se reduz enquanto que a pulmonar aumenta. Tanto as enzimas AA-NAT e ASMT envolvidas na biossíntese da melatonina, quanto as enzimas antioxidantes SOD, CAT e GPx tem suas expressões gênicas no pulmão duplicadas. O envolvimento da melatonina produzida localmente na resolução do processo inflamatório foi atestado através do bloqueio dos receptores de $\mathrm{MT}_{1}$ e $\mathrm{MT}_{2}$ por luzindol, o antagonista, concluindo desta forma que a expressão gênica das enzimas antioxidantes SOD e CAT são moduladas por esta indolamina. 
Conclusões 


\section{CONCLUSÕES}

Após a exposição aguda in vivo ao material particulado fino $\left(\mathrm{MP}_{2,5}\right)$, o presente trabalho possibilitou as seguintes conclusões:

- A presença de elementos provenientes da combustão de combustíveis veiculares fósseis e endotoxinas no material particulado;

- A geração do estresse oxidativo pulmonar dependente do tempo de exposição ao material particulado;

- A ativação do fator de transcrição NF-кB em pulmões de ratos mesmo expostos a um curto período de tempo à poluição, revelando um aumento no conteúdo nuclear do homodímero p50 /p50 e do heterodímero p 50 / Rel A;

- O aumento da expressão basal constitutiva de moléculas de adesão (PECAM1 e ICAM-1) e da enzima sintase de óxido nítrico induzida (iNOS) em veias pulmonares reguladas pelo NF-KB;

- A migração de células fagocíticas MN e PMN para os bronquíolos, aumento do lúmen e espessamento da musculatura lisa bronquiolar;

- A presença plasmática de citocinas pró e anti-inflamatórias (TNF- $\alpha, \mathrm{IL}-1 \beta$, IL1a, INF- $\gamma$, IL-6, IL-2, IL-4, MCP-1 e IL-12);

- A potenciação da corticosterona gerada inicialmente pela câmara poluída na síntese de melatonina pela pineal;

- A redução de 39,0\% na concentração de melatonina plasmática noturna em animais expostos agudamente por 6 horas ao material particulado fino e aumento de $55,0 \%$ nos níveis desta indolamina nos pulmões sob as mesmas condições, caracterizando uma produção extra pineal. Tanto a redução da concentração plasmática quanto ao aumento pulmonar são dependentes do tempo em que o animal ficou exposto à poluição;

- Inalterações dos valores da melatonina plasmática diurna dos animais expostos a diferentes tempos de exposição ao material particulado fino e um acréscimo de $77,0 \%$ na concentração pulmonar de animais expostos também diurnamente e por 6 horas, a partir de uma produção local no referido órgão, tal acréscimo também é dependente do tempo de exposição; 
- A presença da melatonina nos pulmões dos ratos naive e controle independente da hora do dia, com níveis compatíveis à alguns órgãos do trato gastrointestinal;

- Duplicação nas transcrições gênicas das enzimas da biossíntese da melatonina, a AA-NAT e a ASMT após contato com a poluição, sendo também moduladas pelo tempo de exposição ao material particulado fino;

- Duplicação nas transcrições gênicas das enzimas antioxidantes SOD, CAT e GPx também dependentes do tempo de exposição ao material particulado fino;

- $\quad$ Aumento das atividades enzimáticas da SOD, CAT e GPx;

- A transcrição dos genes das enzimas antioxidantes SOD e CAT são dependentes da interação da melatonina com seus receptores, $\mathrm{MT}_{1}$ e $\mathrm{MT}_{2}$, fato não observado com a enzima GPx;

- A normalidade quanto aos níveis da melatonina plasmática e pulmonar é reestabelecida em 24 horas após o término da exposição aguda in vivo ao material particulado fino.

Tais dados não só contribuem para um melhor entendimento a respeito da resposta pulmonar frente à poluição atmosférica de São Paulo como também abrem novas perspectivas com relação ao uso terapêutico da melatonina. A caracterização dos receptores acoplados a proteína $\mathrm{G}, \mathrm{MT}_{1}$ e $\mathrm{MT}_{2}$, como alvos farmacológicos para aumentar a capacidade de defesa pulmonar frente aos contaminantes atmosféricos a partir do aumento da transcrição gênica das enzimas antioxidantes SOD e CAT são a descoberta mais promissora deste trabalho. Trabalhos futuros serão necessários uma vez que precisamos definir o subtipo do receptor de melatonina atuante nesta transcrição, uma vez que utilizamos um antagonista não seletivo, o luzindol. 
Referências 


\section{REFERÊNCIAS*}

ACUÑA-CASTROVIEJO, D. et al. Melatonin-mitochondria interplay in health and disease. Curr. Top Med. Chem., v. 11, p. 221-240, 2011.

ALBARRAN, M. T. et al. Endogenous rhythms of melatonin, total antioxidant status and superoxide dismutase activity in several tissues of chick and their inhibition by light. J. Pineal Res., v. 30, p. 227-233, 2001.

ALLEGRA, M. et al. The chemistry of melatonin's interaction with reactive species. J. Pineal Res., v. 1, p. 1-10, 2003.

AL- KAZWINI, A. T. et al. One-electron oxidation of methoxylates and hydroxylated indoles by azide 1 . Characterization of primary indolic radicals. J. Phys. Chem., v. 94, p. 6666-6670, 1990.

ANDERSON, J. O. et al. Clearing the air: a review of the effects of particulate matter airpollution on human health. J. Med. Toxicol., v. 8, n. 2, p. 166-175, 2012.

ANTOLIN, I. et al. Protective effect of melatonin in a chronic experimental model of Parkinson's disease. Brain Res., v. 943, p. 163-173, 2002.

ANTOLIN, I. et al. Neurohormonemelatonin prevents cell damage: effect on gene expression for antioxidant enzymes. FASEB J., v. 10, p. 882-890,1996.

ARENDT, J. Melatonin and the mammalian pineal gland. London: Chapman \& Hall, 1995. $331 \mathrm{p}$.

ARIMOTO, T. at al. Synergistic production of lung free radicals by diesel exhaust particles and endotoxin. Am. J. Respir. Crit. Care Med.,v. 171, p. 379-387,2005.

ARIS, R. M. at al. Ozone-induced airway inflammation in human subjects as determined by airways lavage and biopsy. Am. Rev. Respir. Dis., v. 148, n. 5, p. 1363-1372, 1993.

AXELROD, J. The pineal gland: a neurochemical transducer. Science, v. 184, n.144, p. 1341-1348, 1974.

BAEUERLE, P. A.; BALTIMORE, D. NF-кB: Ten Years After. Cell, v. 87, p. 13-20, 1996.

\footnotetext{
* De acordo com:

ASSOCIAÇÃO BRASILEIRA DE NORMAS TÉCNICAS. NBR 6023: informação e documentação: referências: elaboração. Rio de Janeiro, 2002.
} 
BALER R. et al. The rat arylalkylamine $\mathrm{N}$-acetyltransferase gene promoter: cAMP activation via a cAMP-responsive element-CCAAT complex. J. Biol. Chem., v. 272, p. $6979-6985,1997$.

BARLOW-WALDEN, L. R. et al. Melatonin stimulates glutathione peroxidase activity. Neurochem. Int., v. 26, n. 5, p. 497-502, 1995.

BECKER, S. et al. Regulation of cytokine production in human alveolar macrophages and airway epithelial cells in response to ambient air pollution particles: further mechanistic studies. Toxicol. Appl. Pharm., v. 207, n. 2, p. 269-275, 2005.

BECKER, S. et al. Response of human alveolar macrophages to ultrafine, fine, and coarse urban air pollution particles. Exp. Lung. Res., v. 29, p. 29-44, 2003.

BECKER, S. et al. Involvement of microbial components and toll-like receptors 2 and 4 in cytokine responses to air pollution particles. Am. J. Respir. Cell Mol. Biol., v. 27, p. 611-618, 2002.

BECKER, S. et al. Stimulation of human and rat alveolar macrophages by urban air particles: effect on oxidant radical generation and cytokine production. Toxicol. Appl. Pharmacol., v. 141, p. 637-648, 1996.

BELL, M. L.; DAVIS, D. L. Reassessment of the lethal London fog of 1952 : novel indicators of the acute and chronic consequences of acute exposure to air pollution. Environ. Helath. Perspect., v. 109, n. 3, p. 389-394, 2001.

BELL, M. L. et al. A retrospective assessment of mortality from the London smog episode of 1952: the role of influenza and pollution. Environ. Health. Perspect., v.112, n. 1, p. 6-8, 2004.

BENÍTEZ-KING, G. Melatoninas a cytoskeletal modulator : implications of cell physiology and disease. J. Pineal Res., v. 40, n. 1, p. 1-9, 2006.

BENÍTEZ-KING, G.; ANTÓN-TAY, F. Calmodulin mediates melatonin cytoskeletal effects. Experientia, v. 49, p. 635-641, 1993.

BERGAMASCHI, L. et al. Comparison between the accumulation capacity of four lichen species transplanted to a urban site. Environ. Pollut., v.148, n. 2, p. 468-476, 2007.

BIANCHI, M. E. DAMPs, PAMPs and alarmins: all we need to know about danger. J. Leukoc. Biol., v. 81, p. 1-5, 2007.

BLANCHARD, B. et al. Nitrosation of melatonin by nitric oxide and peroxynitrite. J. Pineal Res., v. 29, p. 184-192, 2000.

BLOCK, K. I. et al. Impact of antioxidant supplementation on chemotherapeutic toxicity : a systematic review of the evidence of randomized controlled trials. Int. J. Cancer, v. 123, p. 1227-1239, 2008. 
BLASK, D. E. et al. Melatonin-deplet blood from premenopausal women exposed to light at night stimulates growth of human breast cancer xenografts nude rats. Cancer Res., v. 65, n. 23, p. 11174-11184, 2005.

BLOCK, M. L.; CALDERÓN-GARCIDUENAS, L. Air pollution : mechanisms of neuroinflammation and CNS disease. Trends Neurosci., v. 32, n. 9, p. 506-516, 2009.

BOUTHILLIER, L. at al. Acute effects of inhaled urban particles and ozone: lung morphology, macrophage activity, and plasma endothelin-1. Am. J. Pathol., v. 153, n. 6, p. 1873-84, 1998.

BROOK, R. D. et al. Air pollution and cardiovascular disease-a statement for healthcare professionals fromthe expert panel on pop- ulation and prevention science of the American Heart Association.Circulation, v. 109, p. 2655-2671, 2004.

BRYDON, L. et al. Dual signalingof human Mel1a melatonin receptors via Gi2, Gi3 and Gq/11 proteins. Mol. Endocrinol, v. 13, p. 2025-2038, 1999.

BRZEZINSKI, A. Melatonin in humans. N.Engl. J.Med., v. 336, n. 3, p. 186-195, 1997.

BÜBENIK, G. A. et al. Pinealectomy reduces melatonin levels in the serum but not in the gastrointestinal tract of the rat. Biol. Signals., v. 6, p. 40-44, 1997.

CALDERON-GARCIDUENAS, L. et al. 8-hydroxy-2'-deoxyguanosine, a major mutagenic oxidative DNA lesion, and DNA strand breaks in nasal respiratory epithelium of children exposed to urban pollution. Environ. Health Perspect., v. 107, p. 469-474, 1999.

CARRILLO-VICO, A. et al. Melatonin : buffering the immune system.Int. J. Mol. Sci, v. 14, n. 4 , p. 8638-8683, 2013.

CARRILLO-VICO, A. et al. A review of the multiple actions of melatonin on the immune system. Endocrine, v. 27, n. 2, p. 189-200, 2005.

CARVALHO-SOUSA, C. E. Efeito da poluição atmosférica de São Paulo sobre o eixo imune-pineal. 2015. 220 f. Tese (Doutorado em Ciência) - Instituto de Biociência, Universidade de São Paulo, São Paulo, 2015.

CARVALHO-SOUSA, C. E. et al. Molecular basis for defining the pineal gland and pinealocytes as targets for tumor necrosis factor. Front. Endocrinol., v. 2, p. 2-10, 2011.

CERNYSIOV, V. et al. Melatonin inhibits granulocyte adhesion to ICAM via MT3/QR2 and MT2 receptors. Int. Immunol., v. 27, n. 12, p. 599- 608, 2015.

CETESB - Companhia de Tecnologia e Saneamento Ambiental. Relatório Anual de Qualidade do Ar no Estado de São Paulo. São Paulo: CETESB, 2014. 136 p. 
CETESB - Companhia de Tecnologia e Saneamento Ambiental. Relatório Anual de Qualidade do Ar no Estado de São Paulo. São Paulo: CETESB, 2005. 153 p.

CHIRINO, Y. I. et al. PM10 impairs the antioxidant defense system and exacerbates oxidative stress driven cell death. Toxicol. Lett., v. 193, p. 203-216, 2010.

CHU, A. K. M. et al. Study of air pollutants in Hong Kong using energy dispersive Xray fluorescence. Appl. Rad. Isotop., v. 58, p. 333-338, 2003.

CHUANG, K. J. et al. The effect of urban air pollution on inflammation, oxidative stress, coagulation, and autonomic dysfunction in young adults. Am. J. Respir. Crit. Care Med., v.176, p, 370-376, 2007.

CHURG, A. et al. Air pollution particles activate NF-kappaB on contact with airway epithelial cell surfaces. Toxicol. Appl. Pharmacol., v. 208, p. 37-45, 2005.

CONTI, A. et al. Evidence for melatonin synthesis in mouse and human bone marrow cells. J. Pineal Res., v.28, n. 4, p. 193-202, 2000.

COUTO-MORAES, R. et al. The Immune-Pineal Axis: stress as a modulator of pineal gland function. Ann. NY. Acad. Sci., v.1153, p. 193-202, 2009.

CSABA, G.; BARATH, P. Morphological changes of thymus and the thyroid gland after postnatal extirpation of pineal body. Endocrinol. Exp., v.9, p. 59- 67, 1975.

DA SILVEIRA CRUZ-MACHADO, S. et al. TLR4 and CD14 receptors expressed in rat pineal gland trigger NFKB pathway. J. Pineal Res., v. 49, p.183-192, 2010.

DA SILVEIRA CRUZ-MACHADO, S . et al. Glia-pinealocyte network: the paracrine modulation of melatonin synthesis by tumor necrosis factor (TNF). PLoS One, v. 7, n. 7, e40142, 2012.

DAGHER, Z. et al. Role of nuclear factor-kappa B activation in the adverse effects indiced by air polluition particulate matter $(P M 2,5)$ in human epithelial lung cells on culture. J. Appl. Toxicol., v. 27, p. 284-290, 2007.

DE ALMEIDA-PAULA, L.D. et al. Melatonin modulates rat myotube-acetylcholine receptors by inhibiting calmodulin. Eur. J. Pharmacol., v. 525, p. 24-31, 2005.

DE MATOS CAVALCANTE, A. G. et al. Melatonin reduces lung oxidative stress in patients with chronic obstructive pulmonary disease: a randomized, double-blind, placebo-controlled study. J. Pineal Res., v. 53, n. 3, p. 238-244, 2012.

DE OLIVEIRA TATSCH-DIAS, M. et al. The concept of the immune-pineal axis tested in patients undergoing an abdominal hysterectomy. Neuroimmunomodulation, v. 20, p. 205-122, 2013.

DI BELLA, G. et al. Melatonin anticancer effects : review.Int. J. Mol. Sci. , v. 14, n. 2, p. 2410-2430, 2013. 
DONALDSON, K. et al. Ambient particle inhalation and the cardiovascular system : potential mechanisms. Environ. Health Perpect., v. 109, n. 4, p. 523-527, 2001.

DONG, W. et al. Role of endotoxin in tumor necrosis factor a expression. From alveolar macrophage treated with urban air particles. Exp. Lung Res., v. 22, p. 577592, 1996.

DUBOCOVICH, M. L.Pharmacology and function of melatonin receptors. FASEB J., v. 2, p. 2765-2773, 1988.

DUBOCOVICH, M. L. et al. Melatonin receptor antagonists that differentiate between the human Mel1a and Mel1b recombinant subtypes are used to assess the pharmacological profile of the rabbit retina ML1 presynaptic heteroreceptor. NaunynSchmiedeberg's -Arch. Pharmacol., v. 355, n. 3, p. 365-375, 1997.

DUVERNOY, H. M.; RISOLD, P.Y. The circumventricular organs: an atlas of comparative anatomy and vacularization. Brain Res. Rev., v. 56, p. 119-147, 2007.

DYBDAHL, M. et al. Inflammatory and genotoxic effects of diesel particles in vitro and in vivo. Mutat. Res., v. 562, n. 1-2, p.119-131, 2004.

EKSTRÖM, P.; MEISSL, H. Evolution of photosensory pineal organs in new light: the fate of neuroendocrine photoreceptors. Philos. Trans. R. Soc. Lond. B. Biol. Sci., v. 358, n. 1438, p. 1679-1700, 2003.

ELDER, A et al. Translocation of inhaled ultrafine manganese oxide particles to the central nervous system. Environ. Health Perpect., v. 114, n. 8, p. 1172-1178, 2006.

ENGELBRECHT, A. M. et al. Mitochondrial catastrophe during doxorubicin-induced cardiotoxicty : a review of the protective role of melatonin. J. Pinel Res., v. 57, p. 367-380, 2014.

ESQUIFINO, A. I. et al. Circadian organization of the immune response : A role for melatonin. Clin. Appl. Immunol. Rev., v. 4, p. 423-433, 2004.

FAJERSZTAJN, L. et al. Air pollution : a potentially modifiable risk factor for lung cancer. Nat. Rev. Cancer, v.13, n. 9, p. 674-678, 2013.

FERNANDES, P. A. et al. Dual effect of catecholamines and corticosterone crosstalk on pineal gland melatonin synthesis. J. Neuroendocrinol. , v. 69, p. 1-25, 2016.

FERNANDES, P. A. et al. Local corticosterone infusion enhances nocturnal pineal melatonin production in vivo. J. Neuroendocrinol. , v. 21, p. 90-97, 2009.

FERNANDES, P. A. et al. Effect of TNF-alpha on the melatonin synthetic pathway in the rat pineal gland: basis for a 'feedback' of the immune response on circadian timing. J. Pineal Res., v.41, p. 344-350, 2006.

FERREIRA, Z. S. et al. Presence of P2-purinoceptors in the rat pineal gland. Br. J. Pharmacol., v. 415, n. 2-3, p. 33-37, 1994. 
FERREIRA, Z. S. et al. Characterisation of P2Y(1)-like receptor in cultured rat pineal glands. Eur. J. Pharmacol. v. 415, n. 2-3, p. 151-156, 2001.

FERREIRA, Z. S. et al. P2Y(1) receptor activation enhances the rate of rat pinealocyte-induced extracellular acidification via a calcium- dependent mechanism. Pharmacology, v. 69, n. 1, p. 33-37, 2003.

FERREIRA, Z .S. et al. Corticosterone modulates noradrenaline-induced melatonin synthesis through inhibition of nuclear factor kappa B. J. Pineal Res., v.38, p.182188, 2005.

FUJII, T. S. et al. Particulate matter induces cytokine expression in human bronchial epithelial cells. Am. J. Resp Cell Mol. Biol.,v. 25, n. 3, p. 265-271,2001.

FRANCO, D. G.; MARKUS, R. P.The cellular state determines the effect of melatonin on the survival of mixed cerebellar culture. Plos One,v. 9, n. 9, e106332, 2014.

GHIO, A. J. et al. Composition of air pollution particles and oxidative stress in cells, tissues, and living systems. J. Toxicol. Environ. Helath B. Crit. Rev., v.15, n. 1, p. 1-21, 2012.

GHIO, A. J. et al. Concentrated ambienta air particles induce mild pulmonary inflammation in healthy human volunteers. Am. J. Respir. Crit. Care Med., v. 162, p. 981-988, 2000.

GLOIRE, G. et al. NF-kappaB activation by reactive oxygen species: fifteen years later. Biochem. Pharmacol., v. 72, n. 11, p. 1493-1505, 2006.

GROSS, P. M.; WEINDI, A. Peering through the windows of the brain. J. Cereb.Blood Flow Metabol., v. 7, p. 662-671, 1987.

GURGUEIRA, S. et al. Rapid increase in the steady-state concentration of reactive oxygen species in the lungs and heart after particulate air pollution inhalation. Environ.Health Perpec., v. 110, p. 749-755, 2002.

HARDELAND, R. Melatonin: signaling mechanisms of a pleiotropic agent. Biofactors, v. 35, n.2, p.183-192, 2009.

HARDELAND, R. et al. Melatonin. Int. J. Biochem. Cell Biol., v. 38, p. 313-316, 2006.

HARDELAND, R. et al. Oxidation of melatonin by carbonate radicals and chemiluminescence emitted during pyrrole ring cleavage. J. Pineal Res., v. 34, n. 1, p. 17-25, 2003.

HARDELAND, R.; FUHRBERG, B. Ubiquitous melatonin- Presence and effects in unicells, plants and animals. Trends Comp. Biochem. Physiol., v. 2, p. 25-45, 1996. 
HARDELAND, R. et al. On the primary functions of melatonin in evolution: mediation of photoperiodic signals in a unicell, photooxidation, and scavenging of free radicals. J. Pineal Res., v. 18, n. 2, p. 104-111, 1995.

HASSAN, N. A. et al. Impact of climate change on air quality and public health in urban areas. Asia Pac. J. Public Health, v. 168, n. 4, p. 1-11, 2015.

HAUS, E. et al. Chronobiology in hematology and immunology. Am. J. Anat., v. 168, n. 4, p. 467-517, 1983.

HAYDEN, M. S.; GHOSH, S. Celebrating 25 years of NF-KB research. Immunol. Rev., v. 246, n. 1, p. 5-13, 2012.

GHOSH, S.; HAYDEN, M. S. Shared Principles in NF-кB Signaling. Cell, v. 132, p. 344-362, 2008.

HIRAIWA, K.; VAN EEDEN, S.F. Contribution of lung macrophages to the inflammatory responses induced by exposure to air pollutants. Mediators Inflamm., v. 2013 , p. $1-10,2013$.

HOFER, H. Zur morphologie der circumventriculären Organe des Zwischenhirnes der Säugetiere. Verh. Dtsch. Zool. Ges., p. 202-251, 1958.

HOGG, J. C.; VAN EEDEN, S. Pulmonary and systemic response to atmospheric pollution. Respirol., v.14, n. 3, p. 336-346, 2009.

HOLLINGSWORTH, J. W. et al. The role of Toll-like receptor 4 in environmental airway injury in mice. Am. J. Resp.Critic.Care Med., v.170, n. 2, p. 126-132, 2004.

HUSSELL, T.; BELL, T.J. Alveolar macrophages: plasticity in a tissue-specific context. Nat. Rev. Immunol., v. 14, n. 2, p. 81-93, 2014.

ISHII, H. et al. Gene structures, biochemical characterization and distribution of rat melatonin receptors. J. Physiol.Sci., v. 59, n. 1, p. 37-34, 2009.

ISHII, H. et al. Contribution of IL-1 beta and TNF-alpha to the initiation of peripherial lung response to atmospheric particulates (PM10). Am. J.Physiol. Lung Cell Mol. Physiol., v. 287, p.176-183, 2004.

JOHNSON, A. K.; GROSS, P.M. Sensory circumventricular organs and brain homeostatic pathways. FASEB J., v. 7, p. 678-686, 1993.

JONES, D. P. Redefining oxidative stress. Antioxid. Redox Signal., v. 8, n. 9-10, p. 1865-1879, 2006.

JOVANOVICH, S. V.; STEENKEN, S. Substituent effect on the spectral, acid base and redox properties of indolyl radicals : a pulse radiolysis study. J. Phys. Chem., v. 96, n. p. 6676-6679, 1992. 
JUNG, B.; AHMAD, N. Melatonin in cancer management: progress and promise. Cancer Res., v. 66, n. 20, p. 9789-9793, 2006.

KADIISKA, M. B. et al. In vivo evidence of free radical formation in the rat lung after exposure to an emission source air pollution particle. Chem. Res. Toxicol., v.10, p. 1104-1108, 1997.

KAISHO, T.; AKIRA, S. Toll-like receptor function and signaling. J. Allergy Clin. Immunol., v. 117, p. 979-987, 2006.

KALSBEEK, A. et al. Melatonin sees the light: blocking GABA-ergic transmission in the paraventricular nucleus induces daytime secretion of melatonin. Eur. $J$. Neurosci., v.12, p. 3146- 3154, 2000.

KAMPA, M.; CASTANHAS, E. Human health effects of air pollution. Environ. Pollut., v. 151, p. 362-367, 2008.

KELLY, F. J. Oxidative stress: its role in air pollution and adverse health effects. Occup Environ Med., v. 60, n.8, p. 612-616, 2003.

KENNAWAY, D. J.; WRIGHT, H. Melatonin and circadian rhythms. Curr. Top.Med. Chem., v. 2, n. 2, p. 199-209, 2002.

KENNEDY, T. et al. Copper-dependent inflammation and nuclear factor-kappaB activation by particulate air pollution. Am. Respir. Cell. Mol. Biol., v. 19, p. 366-378, 1998.

KINKER, G. S. et al. Melatonergic system-based two-gene index is prognostic in humans gliomas. J. Pineal Res., v. 60, p. 84-94, 2016.

$\mathrm{KIM}, \mathrm{Y} . \mathrm{M}$. et al. Ultrafin carbon particles induce interleukin-8 gene transcription and p38 MAPK ativation in normal human bronchial epithelial cells. Am. J. Physiol. Lung Cell Mol. Physiol., v. 288, p. 432-441, 2005.

KLEIN, D.C. et al. Postsynaptic alpha-adrenergic receptors potentiate the betaadrenergic stimulation of pineal serotonin $\mathrm{N}$-acetyltransferase. Proc. Natl. Acad. Sci., v. 80, n.2, p. 599-603, 1983.

KOTLER, M. L. et al. Melatonin increases gene expression for antioxidant enzymes in rat brain cortex. J. Pineal Res., v. 24, p. 83-89, 1998.

KREWSKI, D. et al. Extended follow-up and spatial analysis of American Cancer Society study linking particulate air pollution and mortality. Res. Rep. Health Eff. Inst., v.140, n. 5-144, p. 5-36, 2009.

KVETNOY, I. M. Extrapineal melatonin: location and role within diffuse neuroendocrine system. Histochem. J., v. 31, n.1, p. 1-12, 1999.

LERNER, A. B. et al. Isolation of melatonin, the pineal factor that lightens melanocytes. J. Am. Chem. Soc., v. 80, n.10, p. 2587, 1958. 
$\mathrm{LI}, \mathrm{N}$. et al. Nrf2 is a key transcription factor that regulates antioxidant defense in macrophages and epithelial cells: Protecting against the pro-inflammatory and oxidizing effects of diesel exhaust chemicals. J. Immunol., v.173, p. 3467-3481, 2004.

$\mathrm{LI}, \mathrm{N}$. et al. Comparison of the pro-oxidative and pro-inflammatory effects of organic diesel exhaust particle chemicals in bronchial epithelial cells and macrophages. $\mathbf{J}$. Immunol., v.169, p. 4531- 4541, 2002.

LIU, J. et al. $\mathrm{MT}_{1}$ and $\mathrm{MT}_{2}$ melatonin receptors : a therapeutic perspective. Annu. Rev. Pharmacol. Toxicol., v.56, p. 361-383, 2016.

LISSONI, P. et al. Decreased toxicity and increased efficacy of cancer usin the pineal hormone melatonin in metastatic solid tumor patients with poor clinical status. Eur. J. Cancer, v. 22, p. 45-47, 2001.

LISSONI, P. et al. Circadian secretion of IL-2, IL-12, IL-6 and IL-10 inrelation to light/dark rhythm of the pineal hormone melatonin in healthy humans. Nat. Immun. , v. 16, p. 1-1692, 1999.

LISSONI, P. et al. Anti-angiogenic activity of melatonin in advanced cancer patients. Neuro Endocrinol., v. 35, p. 1-5, 1998.

LIU, F.; NG, T. B. Effect of pineal indoles on activities of the antioxidant defense enzymes superoxide dismutase, catalase, and glutathione reductase, and levels of reduced and oxidized glutathione in rat tissues. Biochem. Cell Biol., v. 78, p. 447453, 2000.

LONG, C. M et al. A pilot investigation of the relative toxicity of indoor and outdoor fine particles: in vitro effects of endotoxin and other particulate properties. Environ. Health Perspect., v. 109, p. 1019-1026, 2001.

LOPES $\mathrm{C}$. et al. Interaction between the adrenal and the pineal gland in chronic experimental inflammation induced by BCG in mice. Inflamm. Res., v. 50, n.1, p. 6$11,2001$.

LOPES C. et al. Circadian rhythm in experimental granulomatous inflammation is modulated by melatonina. J. Pineal Res., v. 23, n.2, p. 72-78, 1997.

LÓPEZ, A. et al. Melatonin protects the mitochondria from oxidative damage reducing oxygen consumption, membrane potential, and superoxide anion production. J. Pineal Res., v. 46, p.188-198, 2009.

LOTUFO, C. M. et al. Melatonin effect on endothelial cells reduces vascular permeability increase induced by leukotriene B4. Eur. J. Pharmacol., v. 534, n. 1-3, p. 258-263, 2006.

LOTUFO, C. M. et al. Melatonin and $\mathrm{N}$ - acetylserotonin inhibit leukocyte rolling and adhesion to rat microcirculation. Eur. J. Pharmacol., v. 430, n. 2-3, p. 351-357, 2001. 
LUCAS, K.; MAES, M. Role of the toll like recptors (TLR) radical cycle in cronic inflammation: possible treatments targeting TLR4 pathway. Mol. Neurobiol., v. 48, n. 21, p. 190-204, 2013.

MACKENZIE, R. S. et al. Dual coupling of MT1 and MT2 melatonin receptors to cyclic AMP and phosphoinositide signal transduction cascades and their regulation following melatonin exposure. Biohchem. Pharmacol., v. 63, p. 587-595, 2002.

MADDEN, M.C. et al. Acetaldehyde $(\mathrm{CH} 3 \mathrm{CHO})$ production in rodent lung after exposure to metal-rich particles. Free Radical Biol. Med. 26: 1569-77, 1999.

MANTECCA, P. et al. Lung toxicity induced by intratracheal instillation of sizefractioned tire particles. Toxicol. Lett. , v. 189, n. 3, p. 206-214, 2009.

MARKUS, R. P. et al. The immune-pineal axis: a shuttle between endocrine and paracrine melatonin sources. Neuroimmunomodulation, v. 14, p. 126-133, 2007.

MARKUS, R. P. et al. Immune-pineal axis: nuclear factor KB (NF-kB) mediates the shift in the melatonin source from pinealocytes to immune competent cells. Int. J. Mol. Sci., v.14, p. 10979-1097, 2013.

MARSHALL, K. A. et al. Evaluation of the antioxidant activity of melatonin in vitro. Free Radic. Biol. Med. , v. 21, n. 3, p. 307-315, 1996.

MARTíN, M. et al. Melatonin increases the activity of the oxidative phosphorylation enzymes and the production of ATP in rat brain and liver mitochondria. Int. J. Biochem. Cell Biol., v. 34, p. 348-357, 2002.

MARTINS, M.A.G. Variação da composição e toxicidade do matrial particulado ao Ilongo do dia na cidade de São Paulo. 2010. 61 f. Tese (Doutorado em Ciência) - Faculdade de medicina, Universidade de São Paulo, são Paulo, 2015.

MATUSZAK, Z. et al. Reaction of melatonin and related indoles with hydroxyl radicals: ESR and spin trapping investigation. Free Rad. Biol. Med., v.23, p. 367372, 1997.

MAYO, J. C. et al. Melatonin regulation of antioxidant enzyme gene expression. Cell Mol. Life Sci., v.59, p. 1706-1713, 2002.

MERBITZ, $\mathrm{H}$. et al. GIS-based identification of spatial variables enhancing heat and poor air quality in urban areas. Appl. Geograp., v.33, p. 94-106, 2012.

MEDIAVILLA, M. D. et al. Basic mechanism involved in anti-cancer effects of melatonin. Curr. Med. Chem., v. 17, p. 4462-4482, 2010.

MICHAEL, S. et al. Pro-inflammatory effects and oxidatives stress in lung macrophage and epiehelial cells indeced by ambient particulate matter. Environ. Pollut., v. 183, p. 19-29, 2013. 
MILLER, S. C. et al. The role of melatonin in immuno-enhancement: potential application in cancer. Int. J. Exp. Pathol., v. 87, n. 2, p. 81-87, 2006.

MIYATA, R.; VAN EEDEN, S. F. The innate and adaptive immune response induced by alveolar macrophages exposed to ambient particulate matter. Toxicol. Appl. Pharmacol.,v. 257, n. 2, p. 209-226, 2011.

MØLLER M.; BAERES F. M. The anatomy and innervation of the mammalian pineal gland. CellTissue Res., v. 309, p. 139-150, 2002.

MOORE, R.Y. Circadian rhythms: basic neurobiology and clinical applications. Annu. Rev. Med., v. 48, p. 253-266, 1997.

MUDWAY, I. S. et al. An in vitro and in vivo investigation of the effects of diesel exhaust on human airway lining fluid antioxidants. Arch. Biochem. Biophys., v. 423, n. 1, p. 200-212, 2004.

MUNDIGLER, G. et al. Impaired circadian rhythm of melatonin secretion in sedated critically ill patients with severe sepsis. Crit. Care Med., v. 303, n. 3, p. 534-540, 2002.

MUXEL, S. M. et al. The RelA/cRel nuclear factor $\mathrm{kB}(\mathrm{NF}-\mathrm{kB})$ dimer, crucial for inflammation resolution, mediates the transcription of the key enzyme in melatonin synthesis in RAW 264.7 macrophages. J. Pineal Res. v. 63, p. 1-11, 2016.

MUXEL, S. M. et al. NF-KB drives the synthesis of melatonin in RAW 264.7 macrophages by inducing the transcription of the arylalkylamine- $\mathrm{N}$-acetyltransferase (AA-NAT) gene. PLoS One, v. 7, e52010, 2012.

NAIDU, P. S. et al. Possible mecanism of action of melatonin attenuation of haloperidol-induced orofacial dyskinesia. Pharmacol. Biochem. Behav., v.74, p. 641-648, 2003.

NAVARRO-ALARCÓN, M. et al. Melatonin and metabolic regulation: a review. Food Funct., v. 5, p. 2806-2832, 2014.

NEMMAR, A. et al. Passage of inahaled particles into the blood circulation in humans. Circulation, v. 105, n. 4, p. 411-414, 2002.

NEMMAR, A. et al. Passage of intratracheally instilled ultrafine particles from the lung into the systemic circulation in hamster. Am. J. Respir. Crit. Care Med., v. 164, n. 9, p. 1665-1668, 2001.

NERISERNERI, G. G.; BARTOLI, V. Contribution to the study of pineal function. I. Pineal-adrenocortical relations. Rass. Neurol. Veg., v. 12, n. 2-3, p. 211-230, 1957.

$\mathrm{NICHI}$, M. et al. Seasonal variation in semen quality in Bos indicus and Bos taurus bullsraised under tropical conditions. Theriogenology, v. 66, p. 822-828, 2006.

NOSJEAN, O. et al. Identification of the melatonin-binding site MT3 as the quinone reductase 2. J. Biol. Chem., v. 275, n. 40, p. 31311-31317, 2000. 
OBERDORSTER, G. et al. Translocation of inhaled ultrafine particles to the brain. Inhal. Toxicol., v.16, p. 437-445, 2004.

OKATANI, Y. et al. Melatonin increases activities of glutathione peroxidase and superoxide dismutase in fetal rat brain. J. Pineal Res., v.28, p. 89-96, 2000.

O'NEILL, L. A.; KALTSCHMIDT, C. NF-kappa B: a crucial transcription factor for glial and neuronal cell function. Trends Neurosci., v. 20, n. 6, p. 252-258, 2007.

ORTEGA-JIMÉNEZ, V. et al. 24-Hour variation in gene expression of redox pathway enzymes in rat hypothalamus: effect of melatonin treatment. Redox Report, v. 14, n. 3, p. 132-138, 2009.

OSORNIO-VARGAS, A. R. et al. Proinflammatory and cytotoxic effects of Mexico city air pollution particulate matter in vitro are dependent on particle size and composition. Environ. Health Perspect., v. 111, n. 10, p. 1289-1293, 2003.

OZTURK, O. et al. The effecto of melatonin on liver superoxide dismutase activity, serum nitrate and thyroid hormone level. Japa. J. Physiol., v. 50, n. 1, p. 149-153, 200.

PABLOS, M. I. et al. Both melatonin and putative receptor CGP 52608 stimulate glutathione peroxidase and glutathione redutase activities in chick brain in vivo. Neuroendocrinol. Lett. , v. 18, p. 49-58, 1997.

PABLOS, M. I. et al. Melatonin stimulates the activity of the detoxifying enzyme gluthathione peroxidase in several tissues of chicken. J.Pineal.Res., v. 19, p. 111$115,1995$.

PANDI-PERMUAL, S. R. et al. Physiological effects of melatonin: role of melatonin receptors and signal transduction pathways. Prog. Neurobiol., v. 85, p. 335-353, 2008.

PANDI-PERMUAL, S. R. et al. Melatonin - Nature's most versatile biological signal ? FEBS J., v. 273, p. 2813-2838, 2006.

PAUL, M. A. et al. Melatonin treatment for eastward and westward travel preparation. Psychopharmacology., v. 208, n. 3, p. 377-386, 2010.

PARADIES, G. et al. Protective role of melatonin in mitochondrial dysfunctionand related disorders. Arch. Toxicol., v. 89, n. 6, p. 923-939, 2015.

PARADIES, G. et al. Melatonin, cardiolipin and mitochondrial bioenergetics in health and disease. J.Pineal Res. v. 4, p. 297-310, 2010.

PEDERSEN, E. B. et al. Immunocytochemical and electron-microscopic characterization of macrophage/microglia cells and expression of class II major histocompatibility complex in the pineal gland of the rat. (1993). Cell Tissue. Res., v. 272, n. 2, p. 257-265, 1993. 
PÉNARD-MORAND, C.; ANNESI-MAESANO, I. Air pollution: from sources of emission to health effects. Breathe, v. 1, p. $28-39,2004$.

PETERS, A. et al. Translocation and potential neurological effects of fine and ultrafine particles a critical update. Part. Fibre Toxicol., v. 3, n. 13, 2006

PÉVET P. et al. The chronobiotic properties of melatonin. Cell Tissue Res., v. 309, n. 1, p. 183-191, 2002

PIERI C. et al. Melatonin is an efficient antioxidant. Arch. Geriontol. Geriat. , v. 20, 159-165, 1995

PINATO, L. et al. Selective protection of the cerebellum against intracerebroventricular LPS is mediated by local melatonin synthesis. Brain Struct. Funct., v. 220, n. 2, p. 827-840, 2015.

PIRES-LAPA, M. A. et al. Melatonin synthesis in human colostrum mononuclear cells enhances dectin-1-mediated phagocytosis by mononuclear cells. J. Pineal Res., v. 55, p. 240-246, 2013.

POEGGELER, B. et al. Melatonin's unique radical scavenging properties - roles of its functional substituents as revealed by a comparison with its structural analogs. $\mathbf{J}$. Pineal Res.,v. 33, p. 20-30, 2002.

POEGGELER, B. Melatonin, Aging, and Age-Related Diseases: Perspectives for Prevention, Intervention, and Therapy. Endocrine, v. 27, n. 2, p. 201-212, 1996.

POEGGELER, B. et al. Melatonin and structurally-related, endogenous indoles act as a potent electron donor and radical scavengers in vitro. Redox Rep.,v. 2, p. 179-184, 1996.

POEGGELER, B. et al. Melatonin a highly potent andogenous radical scavenger and electron donor : new aspects of the oxidation chemistry of this indole accessed in vitro. Ann. N Y Acad. Sci., v. 738, p. 419-420, 1994.

POLICHETTI, G. et al. Effects of particulate matter (PM10 PM2.5 and PM0.1) on the cardiovascular system.Toxicology, v. 261, n. 1-2, p. 1-8, 2009.

PONTES, G. N. et al. Pineal melatonin and the innate immune response: the TNFalpha increase after cesarean section suppresses nocturnal melatonin production. $\mathbf{J}$. Pineal Res., v. 43, p. 365-371, 2007.

PONTES, G. N. et al. Injury switches melatonin production source from endocrine (pineal) to paracrine (phagocytes) - melatonin in human colostrum and colostrum phagocytes. J. Pineal Res., v. 41, p. 136-141, 2006.

POPE, C. A. III. et al. Fine-particulate air pollution and life expectancy in the United States, New England. J. Med.,v. 360, n. 4, p. 376-386, 2009. 
POPE, C. A., III. et al. Cardiovascular mortality and long-term exposure to particulate air pollution: epidemiological evidence of general pathophysiological pathways of disease. Circulation, v. 109, n. 1, p.71-77, 2004.

POPE, C. A., III. et al. Lung cancer, cardiopulmonary mortality and long-term exposure to fine particulate air pollution.J. Am. Med. Assoc., v. 9, p.1132-1141, 2002.

POPE, C. A. III. Epidemiological basis for particulate air pollution health standards.Aerosol Sci. Tech., v. 32, p. 4-14, 2000.

QUAN, N.; BANKS, W. A. Brain-immune communication pathways. Brain Behav. Immun.,v. 21, n. 6, p. 727-735, 2007.

QUAY, J. L. et al. Air pollution particle induce IL-6 gene expression in human airway epithelial cells via NF-kappaB activation. Am. Respir. Cell Mol.Biol.,v. 19, p. 98106, 1998.

RAASCHOU-NIELSIN, O. et al. Air pollution and lung cancer incidence in 17 european cohorts : prospective analyses from the European Study of Chorts for Air Pollution Effects (ESCAPE). Lancet Oncol., v. 14, n. 9, 813-822, 2013.

RAIKHIJNN, T.; KVENTNOY, M. The synthesis of melatonin and enterochromaffin cells. Arch. Pathol., v. 38, n. 1, 21-25,1976.

REITER, R. J. et al. A review of the evidence supporting melatonin's role as an antioxidant. J. Pineal Res., v. 19, p. 1-11, 1995.

REITER, R. J. The pineal and its hormones in the control of reproduction in mammals. Endocr. Rev.,v. 1, n. 2, p. 109-131, 1980.

REFSNES, M. et al. Different particle determinant induce apoptosis and cytokines release inprimary alveolar macrophage cultures. Part. Fibre Toxicol., v. 3, p. 1-12, 2006.

REN, C. S. et al. Urinary 8-hydroxy-2'- deoxyguanosine as a biomarker of oxidative DNA damage induced by ambient pollution in the normative aging study. Occup. Environ. Med., v. 68, p. 562-569, 2010.

REPPERT, S. M. et al. Molecular characterization of a second melatonin receptor expressed in human retina and brain: the Mel1b melatonin receptor. Proc. Natl. Acad. Sci., v. 92, p. 8734-8738, 1995.

REPPERT, S. M. et al. Cloning and characterization of a mammalian melatonin receptor that mediates reproductive and circadian responses. Neuron, v. 13, p. 1177-1185, 1994.

REPPERT, S. M.; WEAVER, D. R. Coordination of circadian timing in mammals. Nat., v. 418, p. 935-941, 2002. 
Resolução CONAMA (Conselho Nacional do Meio Ambiente) $n^{\circ} 3$, de 28 de junho de 1990.

RHODEN, C. R. et al. N-Acetylcysteine prevents lung inflammation after short-term inhalation exposure to concentrated ambient particles. Toxicol. Sci., v. 79, p. 296303, 2004.

RHODEN, C. R. et al. PM-induced cardiac oxidative stress and dysfunction are mediated by autonomic stimulation. Biochim. Biophys. Acta., v. 1725, p. 305-313, 2005.

RICHARDSON, D. H. S. The use of $x$ ray fluorescence spectrometry for the analysis of plants, especially lichens, employed in biologival monitorind. Sci. Total Environ., v. 175, p. $97-105,1995$.

RIVERO, D. H. et al. Acute cardiopulmonary alterations induced by fine particles matter of São Paulo, Brazil. Toxicol. Sci., v. 85, n. 2, p. 898-905, 2005.

RODRIGUEZ, C. Regulation of antioxidants enzymes : A significant role for melatonin. J. Pineal Res., v. 6, n. 1, p. 1-9, 2004.

RODRIGUEZ, C. G. Projeção da mortalidade e internações hospitalares na rede pública de saúde atribuíveis à poluição atmosférica. Rev. Bras. Estud. Popul., v. 32, n. 3, p. 489-509, 2015.

ROMANO, G. A. Evaluation of 8- hydroxydeoxyguanosine in human oral cells: The importance of tobacco smoke and urban environment. Anticancer Res., v. 20, p. 3801-3805, 2000.

SAKAI, Y. et al. Central GABAergic innervation of the mammalian pineal gland: a light and electron microscopic immunocytochemical investigation in rodent and nonrodent species. J. Comp. Neurol., v. 430, n. 1, p. 72-84, 2001.

SALDIVA, P.H. N. et al. Air pollution: a potent modifiable risk factor for lung cancer. Nat. Rev. Cancer., v. 13, p. 674-678, 2013.

SALDIVA, P. H. N. et al. Lunginflamation induced by concentrated ambient air particles is related to particle composition. Am. J. Respir. Crit. Care Med., v. 165, n. 12, p. 1610-1617, 2002.

SALDIVA, P. H. N. Análise dos efeitos do Programa de Controle de Emissões Veiculares - Proconve - sobre indicadores de mortalidade na Região Metropolitana de São Paulo. 2006. 180 f. Tese (Livre-docência) - Faculdade de Medicina, Universidade de São Paulo, São Paulo, 2006.

SAMET, J. M. et al. Fine particulate air pollution and mortality in 20 United States cities 1987-1994. New Eng. J. Med., v. 343, n. 24, p. 1742-1749, 2000. 
SARNAT, J. A. et al. Gaseous pollutants in particulate matter epidemiology: confounders or surrogates? Environ. Healh Perspec., p. 109, n. 10, 1053-1061, 2001.

SATO T. et al. Expression of class II MHC molecules in the rat pineal gland during development and effects of treatment with carbon tetrachloride. Cell Tissue Res., v. 284, p. 65-76, 1996.

SAWYER, K. et al. The effect of ambient particulate matter on human alveolar macrophage oxidative inflammatory response. J. Toxicol. Environ. Health, v. 73, n. 1, p. 41-57, 2010.

SCHRÖDER, $H$. et al. Neuronal markers in the rodent pineal gland - an immunohistochemical investigation. Histochemistry, v. 94, p. 309-314, 1990.

SCHWARTZ, J. Air pollution and daily mortality: a review and meta analysis. Environ. Res., v. 64, n. 1, p. 36-52, 1994.

SCHULTZ, T. F.; KAY, S. A. Circadian clocks in daily and seasonal controlo $f$ development. Science, v. 301, n. 5631, p. 326-328, 2003.

SEATON, A. et al. Particulate air pollution and acute helath effects. Lancet, v. 345, n. 8943, p.176-178, 1995.

SILVA, S.O. et al. Melatonin and its kynurenin-like oxidation products affect the microbicidal activity of neutrophils. Microbes Infect., v. 8, n. 2, p. 420-425, 2006.

SIOUTAS, C. et al. Fine particles concentrators for inhalation exposures - Effect of particle size and composition. J. Aerosol Sci. , v. 28, p. 1057-1071, 1997.

SIOUTAS, C. et al. Development and evaluation of a prototype ambient particle concentrator for inhalation exposure studies. Inhal. Toxicol., v. 7, p. 633-644, 1995.

SIMONNEAUX, V.; RIBELAYGA, C. Generation of the melatonin endocrine message in mammals: a review of the complex regulation of melatonin synthesis by norepinephrine, peptides, and other pineal transmitters. Pharmacol. Rev., v. 55, p. 325-395, 2003.

SHOENFELT, J. et al. Involvement of TLR2 and TLR4 in inflammatory immune responses induced by fine and coarse ambient air particulate matter. J. Leukoc. Biol., v. 86, p. 303-312, 2009.

SHOKRZADEH, M. et al. Protective effects of melatonin against cyclosphosphamidainduced oxidative lung toxicity in mice. Drug Res., v. 65, p. 281-286, 2015.

SHUKLA, A. et al. Inhaled particulate matter causes expression of nuclear facto (NF)-kappaB-related genes and oxidant NF-kappaB activation in vitro. Am. J. Respir. Cell Mol. Biol., v. 23, p. 182-187, 2000.

SKWARLO-SONTA, K. et al. Bidirectional communication between the pineal gland 
and the immune sysytem. Can. J. Physiol. Pharmacol., v. 81, n. 4, p. 342-349, 2003.

SKWARLO-SONTA, K. Functional connections between the pineal gland and immunesystem. Acta Neurobiol. Exp., v. 56, p. 341-357,1996.

SLOMINSKI A. et al. On the Role of Melatonin in Skin Physiology and Pathology. Endocrine, v. 27, n. 2, p. 37-148, 2005.

SOUKUP, J. M.; BECKER, S. Human alveolar macrophage responses to air pollution particulates are associated with insoluble components of coarse material, including particulate endotoxin. Toxicol. Appl. Pharmacol., v. 171, p. 20-26, 2001.

STEPHENS, W. E.; CALDER, A. Analysis of non-organic elements in plant foliage using polarised X-ray fluorescence spectrometry. Anal. Chim. Acta, v. 527, p. 89-96, 2004.

TAKENAKA, S. et. al. Pulmonary and systemic distribution of inhaled ultrafine silver particles in rats. Environ. Health Perspect., v. 109, n. 4, p. 547-551, 2001.

TAMURA, E. K. et. al. Long lasting priming of endothelial cells by plasma melatonin levels. Plos One, v. 5,n. 1, p. e13958, 2010.

TAMURA, E. K. et. al. Melatonin inhibits LPS-induced NO production in rat endothelial cells. J. Pineal Res., v. 46, p. 268-274, 2009.

TAN, D. X. et al. Mitochondria and chloroplasts as the original sites of melatonin synthesis: a hypothesis related to melatonin's primary function and evolution in eukaryotes. J. Pineal Res., v. 54, p. 127-38, 2013.

TAN, D. X. et al. The changing biological roles of melatonin during evolution: from an antioxidant to signals of darkness, sexual selection and fitness. Biol. Rev., v. 85, p. 607-623, 2010.

TAN, D. X. et al. Melatonin directly scavenges hydrogen peroxide: a potentially new metabolic pathway of melatonin biotransformation. Free Rad. Biol. Med., v. 29, p. 1177-1185, 2000.

TAN, D. X. et al. Melatonin: a potent endogenous hydroxyl radical scavenger. Endocr. J., v. 1, p. 57-60, 1993.

TECLEMARIAM-MESBAH, R. et al. Anatomical demonstration of the suprachiasmatic nucleus-pineal pathway. J. Comp. Neurol., v. 406, n. 2, p. 171-182, 1999.

TRAENCKNER, R. et al. Phosphorylation of human I kappa B-alpha on serines 32 and 36 controls I kappa B-alpha proteolysis and NF-kappa B activation in response to diverse stimuli. EMBO J., v. 14, n. 12, p. 2876-2883, 1995.

TSAI, S. Y. et al. Microglia play a role in mediating the effects of cytokines on the 
structure and function of the rat pineal gland. Cell Tissue Res., v. 303, n. 3, p. 423431, 2001.

TURJANSKI, A. G. et al. Scavenging of NO by melatonin. J. Am. Chem. Soc., v. 122, n. 3, p. 10468-10469, 2000.

TZAVARA, E. T. et al. Diurnal variation of the adenylyl cyclase type 1 in the rat pineal gland. Proc. Natl. Acad. Sci. USA, v. 93, n. 20, p. 11208- 11212, 1996.

VAN BERLO, D. et al. NF-kappaB dependent and independent mechanisms of quartz-induced proinflammatory activation of lung epithelial cells. Part Fibre Toxicol., v, 21, p. 7-13, 2010.

VAN EEDEN, S. F. et al. Systemic response to ambient particulate matter: relevance to chronic obstructive pulmonary desease. Proc. Am. Thorac. Soc., v. 2., n. 1, p. 61-67, 2005.

VAN EEDEN, S. F.; HOGG, J.C. Systemic inflammatory response indeuced by particulate matter air pollution: the importance of bone-marrow stimulation. J.Toxicol.Environ.Health, v. 65, n.20, p. 1597-1613, 2002.

VAN EEDEN, S. F. et al. Cytokines involved in the systemic inflammatory response induced by exposure to particulate matter air pollutants (PM10). Am. J. Respir. Crit. Care Med., v. 164. p. 826-830, 2001.

VAUGHAN, M. K.; REITER R. J. Transient hypertrophy of the ventral prostate and coagulating glands and accelerated thymic involution following pinealectomy in the mouse. Tex. Rep. Biol. Med., v. 29, n. 4, p. 579-586, 1971.

VOLLRATH, L. The pineal organ. Handbuch der mikroskopischen antomie des menschen. Berlin: Springer Verlag, 1981. v. 7.

WEI, Y. et al. PM2.5 constituents and oxidative DNA damage in humans. Environ. Sci. Technol., v. 43, p. 4757-4762, 2009.

WICHMANN, H. E.; PETERS, A., Epidemiological evidence of the effects of ultrafine particle exposure. Phil. Trans. R. Soc. Lond., v. 358, p. 2751-2769, 2000.

WIEBERT, P. et al., No signficant translocation of inhaled $35-\mathrm{nm}$ carbon particles to the circulation in humans. Circulation., v.105, n.4, p. 411-414, 2006a.

WIEBERT, P. et al. Negligible clearence of ultrafine particles retained in healthy and affected human lungs. Eur. Respir. J. ,v. 28, n. 2, p. 286-290, 2006b.

WORLD HEALTH ORGANIZATION (WHO). The top 10 causes of death. Relatório. Genebra: WHO, 2014. 4 p.

WORLD HEALTH ORGANIZATION (WHO). Burden of disease from Ambient Air Pollution for 2012. Relatório. Genebra: WHO, 2012. 3 p. 
WORLD HEALTH ORGANIZATION (WHO). Guideline for particulate matter, ozone, nitrogen, dioxide and sulfer dioxide. Guia. Genebra: WHO, 2006. 20 p.

WURTMAN, R.J.; AXELROD, J. The Pineal Gland. Sci. Am., v. 213, p. 50-60, 1965.

WURTMAN, R.J. et al. Photic And Neural Control Rhythm Gland Of In The Pineal Gland: Control By Light. Science., v. 157, p. 487- 492, 1963.

YAMASOE, M. A. Estudo da composição elementar e iônica de aerossóis emitidos em queimadas na Amazônia.1994. 57 f. Tese (Mestrado em Ciências Atmosféricas) - Instituto de Física, Universidade de São Paulo, São Paulo, 1994.

YIN, X. J. et al. Roles of reactive oxygen species and heme oxygenase 1 in modulation of alveolar macrophage-mediated pulmonary immune responses to Listeria monocytogenes by diesel exhaust particles. Toxicol. Sci., v. 82, n.1, p. 143 $-153,2004$.

ZANG, L. Y. et al. Scavenging of reactive oxygen species by melatonin. Biochem. Biopfys. Acta.,v. 1425, p. 467-477, 1998.

ZHAO, $\mathrm{H}$. et al. Reactive oxygen species and nitric oxide mediated lung inflammation and mitochondrial dysfunction in wild-type and iNOS-deficient mice exposed to diesel exhaust particles. J. Toxicol. Environ. Health.,v. 72, p. 560-570, 2009.

ZHOU, L. Z. et al. NF kappa B and AP-1mediate transcriptional responses to oxidative stress in skeletal muscle cells. Free Radic. Biol.Med., v. 31, p. 1405-1416, 2001.

ZLOTOS, D. P. et al. MT1 and MT2 melatonin receptors: ligants, models, oligomers and potential. J. Med. Chem., v. 57, 3161-3165, 2014. 